\title{
A Delphi Study Exploring the Impact and Feasibility of Entrepreneurial Initiatives in College/University Kinesiology Programs
}

Cory Breithoff

West Virginia University, cbreitho@mix.wvu.edu

Follow this and additional works at: https://researchrepository.wvu.edu/etd

Part of the Health and Physical Education Commons, Higher Education Commons, and the Online and Distance Education Commons

\section{Recommended Citation}

Breithoff, Cory, "A Delphi Study Exploring the Impact and Feasibility of Entrepreneurial Initiatives in College/University Kinesiology Programs" (2020). Graduate Theses, Dissertations, and Problem Reports. 7709.

https://researchrepository.wvu.edu/etd/7709

This Dissertation is protected by copyright and/or related rights. It has been brought to you by the The Research Repository @ WVU with permission from the rights-holder(s). You are free to use this Dissertation in any way that is permitted by the copyright and related rights legislation that applies to your use. For other uses you must obtain permission from the rights-holder(s) directly, unless additional rights are indicated by a Creative Commons license in the record and/ or on the work itself. This Dissertation has been accepted for inclusion in WVU Graduate Theses, Dissertations, and Problem Reports collection by an authorized administrator of The Research Repository @ WVU.

For more information, please contact researchrepository@mail.wvu.edu. 
A Delphi Study Exploring the Impact and Feasibility of Entrepreneurial Initiatives in College/University Kinesiology Programs

Cory Lea Breithoff, M.S.

Dissertation submitted to the College of Physical Activity and Sports Sciences Department of Coaching and Teaching Studies at West Virginia University

In partial fulfillment of the requirements for the degree of Doctorate of Philosophy in Coaching and Teaching Studies

Sean M. Bulger, Ed.D., Chair

Eloise Elliott, Ph.D.

Dana K. Voelker, Ph.D

Valerie K. Wayda, Ed.D.

Morgantown, West Virginia

May 2020

Keywords: entrepreneurial initiatives, feasibility, impact, kinesiology Copyright 2020 Cory Breithoff 


\section{ABSTRACT \\ A Delphi Study Exploring the Impact and Feasibility of Entrepreneurial Initiatives in College/University Kinesiology Programs}

\section{Cory Lea Breithoff}

Background: Even though higher education institutions have dotted the American landscape for hundreds of years, only over the past couple of decades did it become evident that significant change is necessary as outside stakeholders begin to encroach on the ivory tower (Barnett, 2004). As public revenue sources continue to dwindle, and society urges institutions to freeze their everincreasing tuition rates, colleges and universities must be creative with their methods to increase their internal revenue. While kinesiology programs have begun to discuss such methods, it is now essential to evaluate what is possible in terms of feasibility and what is worth the effort in terms of financial impact. The purpose of this study was to gain a consensus of expert opinion regarding the impact and feasibility of entrepreneurial initiatives in higher education and to generate a list of facilitators and barriers that may impact the implementation of initiatives in their department. Methods: A total of 20 expert panelists comprised of higher education kinesiology administrators and leaders participated in a two-round Modified Delphi study to explore the impact and feasibility of entrepreneurial initiatives as well as facilitators and barriers of implementation of said initiatives. Results: The results of this study indicated that the three areas most worthy of entrepreneurial efforts are student recruitment, summer and intersession blended learning, and community partnerships. Additionally, before beginning any implementation of new academic revenue streams, kinesiology professionals need to consider the following aspects in their department: (a) support, (b) belief, (c) time, and (d) money, all of which can be a facilitator or barrier depending on how they are expressed internally.

Conclusion: There is no universal solution for decreasing revenue streams in higher education kinesiology departments, but there is a multitude of options that leaders can implement. Although this study did not produce an exact list for each context, the hope is that the results of this study will inspire kinesiology leaders and professionals to evaluate their situation and begin to establish new revenue streams to help their program remain viable. Future research should include case studies on highly entrepreneurial departments in an effort to build a framework for others to follow. 


\section{Dedication}

This is firstly dedicated to my mom, my biggest inspiration. Thank you for "forcing" your children into the four-year degree you never had an opportunity to pursue and for supporting me every step of the way for the next $6+$ years. I love you.

This is also dedicated to the rest of my amazing family who has encouraged and hounded me every step of the way, Dad, Dan, \& Dean. Thank you and I love you. 


\section{Acknowledgements}

Daniel, even though I have been in school for what feels like half my life and having been writing this paper for what has been half of that, you are still better with your words. Thank you for loving me and for being so patient and kind, even when I am not. You are the most remarkable human I know; I am so proud to be your partner and your wife. I love you.

Mom \& Dad, thank you for all you have done for me. There are no better parents in the world than you two. You have pushed me for as long as I can remember, always on the sidelines, being the biggest cheerleaders for your cheerleader. There is no way I can ever repay you for all you have done, I love you.

Dean, thank you for letting me be your shadow. If it wasn't for you choosing WVU all those years ago, I would have never been here. You have always been my idol, love your baby sister.

Ashley, thank you for being the sister I never had. You have been here for the entire decade-plus of my higher education career, always keeping my head above water. You are the best friend I could ever imagine.

The Moskovich Family, thank you for all your support throughout the last six years of my graduate school adventure. Thank you for treating me as one of your own and always welcoming me with open arms into your family.

To my committee members, Dr. Bulger, I don't know how you did it, putting up with me for over a decade, but you (and I) survived. You are one of the wisest and most patient people I know, thank you for all your guidance and support. Dr. Elliot, thank you for your non-stop support, even though you never had to answer my texts and calls, you always did. You are one of a kind and easily one of the most impressive women I have ever met. Never change! Dr. Wayda 
\& Dr. Voelker, thank you both for joining my committee and for supporting me throughout my academic journey. I am in awe of your professionalism and intelligence on a daily basis.

Adam, Brooke, and Hannah (in no order), thank you. Thank you for being my subcommittee and answering and assisting me with everything, both academic and non-academic. I don't have a clue how this Jersey girl got so lucky as to have such amazing people in my life. You all bring out the best in me.

Lastly, they say it takes a village and I ended up with an entire city. Thank you to all the people who have helped me and supported me throughout this journey, it's been a crazy ride. Thank you to the old office crew who always seemed to find a way to have fun amongst the stress (Karl, Natasha, Jun, James, and Lynda). Thank you to the Wyant family, I love you all, you are amazing humans. Thank you to all the friends and family who have continued to stay on me every time I see them. (Aunt Jacquie, Tiara Foster, Mandi Jensen, and Tammy Hanna). There is no way I would have survived any of this without you all, thank you to my collection of wonderful people I have accumulated throughout the years, I love you all. 


\section{TABLE OF CONTENTS}

\section{INTRODUCTION}

Purpose and Statement of Problem

Research Questions

METHOD

Research Design

Participants

Instrumentation

Instrument design

Administrative Procedures

Round 1 procedures

Round 2 procedures

Data management 15

Data Analysis $\quad 15$

$\begin{array}{ll}\text { Entrepreneurial initiatives } & 15\end{array}$

$\begin{array}{ll}\text { Facilitators and barriers } & 16\end{array}$

$\begin{array}{ll}\text { RESULTS } & 16\end{array}$

$\begin{array}{ll}\text { Student Recruitment } & 18\end{array}$

Summer and Intersession Blended Learning $\quad 20$

Distance Learning Articulation Agreements 21

Distance Learning Course Licensing $\quad 22$

$\begin{array}{ll}\text { Applied and Professional Master's } & 23\end{array}$

Customized Corporate Training and Partnerships 24

Seniors' Enrichment Programs 25

$\begin{array}{ll}\text { Testing and Certifications } & 26\end{array}$

$\begin{array}{ll}\text { Faculty Consulting } & 27\end{array}$

Community Partnerships 28

Effects on Implementation $\quad 29$

$\begin{array}{ll}\text { DISCUSSION } & 30\end{array}$

$\begin{array}{ll}\text { Practical Implications } & 38\end{array}$

$\begin{array}{ll}\text { Strengths and Limitations } & 38\end{array}$

$\begin{array}{ll}\text { Future Directions } & 39\end{array}$

$\begin{array}{ll}\text { Conclusion } & 40\end{array}$

$\begin{array}{ll}\text { REFERENCES } & 41\end{array}$

APPENDICES $\quad 52$

A. Extended Literature Review $\quad 52$

B. Definition of Key Terms 103

C. Research Method Flowchart 105

D. Initial E-mail Request for Participation 106

E. Recruitment Advertisement 107 
F. IRB Flex Consent Form 109

G. Demographic Survey 111

H. Round 1 Cover Letter 113

$\begin{array}{ll}\text { I. Round } 1 \text { Survey Instrument } & 115\end{array}$

J. Entrepreneurial Initiative Descriptions PDF Attachment 118

K. Round 2 Cover Letter 126

L. Round 2 Survey Instrument 128

M. Round 2 Attachment (Round 1 Means Data) 132

N. Curriculum Vitae 


\section{LIST OF TABLES}

Table

Page

1. Student Recruitment

2. Summer and Intersession Blended Learning 21

3. Distance Learning Articulation Agreements 22

4. Distance Learning Course Licensing 22

5. Applied and Professional Master's 23

6. Customized Corporate Training and Partnerships 25

7. Seniors' Enrichment Programs 26

8. Testing and Certifications 27

9. Faculty Consulting 28

10. Community Partnerships 29 


\section{LIST OF FIGURES}

Figure

Page

1. Individual Entrepreneurial Initiative Items

17

2. Entrepreneurial Initiative Item Group Averages 


\section{Introduction}

Although higher education in America has existed for hundreds of years, many of its traditional components require transformation (Hendrickson, Lane, Harris, \& Dorman, 2013). Higher education can no longer be characterized as solely an elite education focused on the upper-echelon of society with the primary intent of expanding one's mind for the sake of selfgrowth, the isolated years spent in higher education, and robust public financial support streams (Snyder, 1993). American higher education is now confronted with complex issues (increasing expenditures, decreasing funding, external stakeholder interference, and changing clientele) that are difficult to solve using traditional approaches. Moving forward, faculty and administrators must consider expectations that stretch beyond campus, the associated constraints, and resultant strategies for doing more with less daily (Barnett, 2000, 2004). If the American higher education system is to remain viable, university faculty and administrators must think innovatively and entrepreneurially when approaching the complexities associated with modern-day learning (Block \& Estes, 2011).

It is predicted that within the next $10-15$ years, as many as $50 \%$ of colleges and universities will be bankrupt, and the closure rates of smaller schools could triple, while mergers double (Christensen \& Eyring, 2011). While these numbers are disturbing, this economic downturn in higher education did not occur overnight. American higher education institutions have been impacted by disruptive innovation, mainly through the means of online education opportunities. Disruptive innovation reflects the notion that the product introduced, which later takes over a market, is not necessarily better, just more accessible, and often less expensive (Christensen \& Eyring, 2011). While other non-traditional learning opportunities and venture avenues may have at first been overlooked by traditional higher education institutions, it is now 
more imperative than ever that colleges and universities continue to build their future by making strategic investments in innovation.

The need for innovation in higher education is not new when one considers the past and how higher education in America has evolved. The history of American higher education mirrors that of the growing nation it served for the past few centuries. There has been a shift in focus from religion and liberal arts, to the need for a practical education that leads to employment and societal advancement (Brint, Turk-bicakci, \& Levy, 2016; Meyer, 1975; Tewksbury, 1965). Student bodies have become more diverse from adding women and minorities, to accepting nontraditional students and individuals with disabilities, and now a global learning community (Snyder, de Brey, \& Dillow, 2016; Snyder, 1993). Colleges and universities began to expand beyond one or two brick and mortar facilities, to today's sprawling campuses, community colleges, inter-institutional partnerships, and more recently online learning to meet better the needs of this diverse population of learners (Snyder, 1993; Trow, 2006). Also, there have been significant changes in funding, closely tied with the perception of the purpose of higher education by Americans and the broader economic climate of the nation (Snyder et al., 2016).

While adapting to change is nothing new to higher education, its accelerated pace during recent decades highlights the importance and impact of disruptive innovation (Christensen \& Eyring, 2011). To be successful moving forward, higher education administrators must understand how their institution functions not only on its own but also with a myriad of external stakeholders, such as the surrounding community, corporations, and governing bodies. Leaders must take into account new complex environmental forces, including changing demographics, increased competition, additional regulations, and decreased funding that contends with traditional higher education issues (Hendrickson et al., 2013). These complexities can be 
illustrated to a greater extent through the use of supercomplexity as an organizing conceptual framework (Barnett, 2000).

While frameworks have long been in existence to enable society to navigate a complex world, these traditional frameworks often interact and sometimes compete with one another in a multifaceted manner that has been described as supercomplexity (Barnett, 2000). When applying this idea to higher education, the influencing elements of supercomplexity create turmoil and disruption: (a) globalization, (b) digital technologies, (c) interpenetration of the wider society, (d) equal participation, access, and opportunities, (e) marketization, (f) competition, and (g) quality evaluation. All of these elements must be continually and simultaneously assessed, as they challenge past thinking related to the academy, intellectual integrity, knowledge production and dissemination, and relationships shared with all stakeholders (Block \& Estes, 2011). It is imperative to note that although these elements often overlap, intersect, and affect one another, they still offer an opportunity to ground common modern issues into categories leaders can discuss and strategic plan for (Barnett, 2004).

Kinesiology in higher education is not immune to the issues of financial constraints, increasing expectations, and heavy outside pressure. As a result, it finds itself operating in a supercomplex environment. Supercomplexity has been used as a framework to analyze the current status of kinesiology in higher education (Block \& Estes, 2011). Block and Estes (2011) found that given these complexities, kinesiology professionals have a responsibility to generate overarching ideas and solutions that lead the profession into the future, and they can no longer function through more narrow frameworks of meaning. Kinesiology professionals need to interact with the globalized world and must be willing to communicate with the wider society in addition to their intellectual counterparts. Also, kinesiology departments must establish sound 
business practices, clear mission statements, and streamlined bureaucracies. Higher education professionals in kinesiology should also engage in entrepreneurial endeavors that meet the needs of society if they are to remain viable moving forward (Block \& Estes, 2011).

As higher education continues to become more complex and academic programs are asked to do more with less, it becomes necessary to take a more in-depth look at funding. Funding in higher education has historically been derived from public sources, at local, state, and federal levels, and tuition from students. While this model of revenue was stable for many decades, it has become apparent that there is a need to be innovative when it comes to revenue generation (Zusman, 2011). Public financial support for higher education has been in existence for hundreds of years, although the level and amount of support has varied. Federal and state appropriations for higher education increased over time, hitting peaks during what was considered its golden age in the late 1960s and early 1970s (Snyder, 1993). This increased funding allowed for the expansion of higher education throughout the country. By 1980, state appropriations accounted for an average of 44 percent of total revenue in higher education, and federal sources accounted for another 2.6 percent. These numbers, however, have been in steady decline since, with recent years, amounting to 17 percent and .51 percent state and federal funding, respectively (Snyder et al., 2016). This significant decrease in funding, coupled with increasing expectations related to purpose, diversity, and campus growth, present higher education leaders with critical fiscal challenges.

While supercomplexity brings about challenges and changes, it represents an opportunity for higher education to reinvent itself with a renewed focus on solving societal problems and issues in new ways (Block \& Estes, 2011). As Block and Estes (2011) urged, one possible way to take on these issues is through entrepreneurial initiatives (EIs). While characteristics of 
entrepreneurship, innovation, and experimentation have long been facets of higher education, they have often been done for the primary purpose of generating knowledge, not revenue (Boehm, 2008; Zusman, 2011). It was not until more recent decades that these traditional concepts of the academy were used as means of intentional revenue generation. Based on the current financial climate, it is more essential than ever before for higher education professionals to be entrepreneurial in their everyday decision-making. Higher education must look for a way to not only maintain itself but continue advancing, and this includes exploring new revenue streams.

While entrepreneurship has been studied in higher education over the past decades, it is mostly related to university spin-offs and patents (Boehm, 2008). It is now necessary to take a closer look at academic entrepreneurship or the commercialization of academic concepts, and how institutions are using innovation to remain fiscally viable and competitive. Higher education consulting groups, such as the Educational Advisory Board (EAB), have emerged as essential catalysts for change in this area. For example, EAB (2013) identified multiple strategies for developing new educational revenue streams that are potentially applicable to kinesiology programs during these financially straining times. Some of these strategies encompass unique learning opportunities, partnerships, testing and certification, and faculty as entrepreneurs.

Despite the lack of research on entrepreneurial initiatives in higher education kinesiology departments, it is evident through observation that innovation is occurring in the areas highlighted in the previous section (unique learning opportunities, partnerships, testing and certification, and faculty as entrepreneurs). One area of academic entrepreneurship that is evident is online learning, which has become increasingly popular. From the 2003-2004 academic school year to the 2015-2016 year, there has been an $11.1 \%$ increase in undergraduate students taking 
an online course and a $7 \%$ increase in students completing their degree entirely online.

Additionally, there have been significant increases with graduate students completing some (29.1\% increase) or all (21.2\% increase) of their degree programs online (Snyder et al., 2016). Since higher education can be attended at any time from any place and with one in every three students participating in online programming, enrollment numbers in online programs are soaring (Hanover Research, 2018). Additionally, students no longer attend higher education for a prescribed amount of time; instead, they are becoming fluid learners who return for more education across their long careers (UPCEA, 2018). As a result of this growth in online learning, many departments have begun to make the switch to online programs, offering innovative undergraduate, graduate, and non-degree certifications to a wide variety of learners.

Kinesiology departments with a heavy focus on exercise science have found profitable partnerships with their athletic departments and the outside community. One example of a successful program using their academic skill as a marketable product is the Fitness Institute of Texas (FIT). This program, which began in 2001 by the Department of Kinesiology and Health Education at the University of Texas, now performs over 2,000 fitness evaluations a year and has also created nutritional services and exercise programs (College of Education at The University of Texas at Austin, 2019). In addition to departments, faculty members are marketing their innovations as spinoffs. There have been online companies related to active classroom instruction, physical education instruction, and afterschool physical activity related to children's programs started throughout the country.

It is evident that some in the field of kinesiology are thinking entrepreneurially. However, for those struggling to implement innovative revenue streams, it is imperative to learn more about the impact and feasibility of possible initiatives. It is also crucial for kinesiology 
professionals to have the proper infrastructure to be successful in the area of academic entrepreneurship. This includes the creation of support programs, marketing and development, and joint venture models. Kinesiology professionals will need to consider facilitators and barriers as well before investing their limited discretionary time, effort, and other resources in launching new entrepreneurial initiatives. While higher education continues to operate in an environment of increased expectations with decreasing financial support, entrepreneurial approaches offer universities, colleges, and departments a unique opportunity for reinvention.

\section{Purpose and Statement of the Problem}

Much like higher education in general, departments of kinesiology are confronted by numerous challenges and opportunities associated with the supercomplex environment in which they operate. There is a continued need to validate the purpose of the field, entice and meet the demands of a variety of learners and keep up enrollment as traditional college-aged students matriculate at lower rates, all at the same time state-funded revenue streams are still decreasing. Although entrepreneurial behaviors are now widely encouraged in higher education, the impact and feasibility of these types of initiatives have not yet been systematically evaluated in relation to departments of kinesiology. The purpose of this exploratory study was to (a) gain a consensus of expert opinion from leaders in kinesiology departments regarding the impact and feasibility of entrepreneurial initiatives in higher education, and (b) to generate a list of facilitators and barriers that may impact the implementation of entrepreneurial initiatives in their departmental context.

\section{Research Questions}

1. What are the perceived impact and feasibility of selected entrepreneurial initiatives for higher education kinesiology departments? 
2. What is the consensus of expert opinion regarding the most impactful and feasible entrepreneurial initiatives for higher education kinesiology departments?

3. What are facilitators and barriers to the implementation of entrepreneurial initiatives?

\section{Method}

\section{Research Design}

The lack of literature related to entrepreneurship in higher education kinesiology encourages the use of alternative research design, such as the Delphi method, which can provide a systematic protocol to forecast change through group communication. The RAND corporation initially developed the Delphi method as a way to collect and organize an expert opinion (Clayton, 1997). Since its development, the Delphi method has been used to research a wide variety of educational issues, including the future of adult education (Lierman, 1996), distance education (Miller \& Husmann, 1994), and marketing teacher education (Smith, 1992). These complex issues benefit from the Delphi method, as it capitalizes on the ability to enhance decision making by allowing the researcher to gain a consensus from a group of experts about a particular topic without concern for constraints related to time and expense associated with faceto-face research methods (Clayton, 1997).

\section{Participants}

An integral part of a Delphi investigation relates to the selection of participants, otherwise known as expert panel members. The act of purposively selecting experts based on their knowledge and experiences is what gives the Delphi method superiority and validity over survey procedures (Clayton, 1997). Throughout the selection process, it is imperative to select prospective panel members who have a level of expertise regarding the specific area of questioning. This level of expertise implies that the individual panelists have more knowledge 
about the subject matter than most people, or, such as in this study, are members in a relevant professional association (Murray \& Hammons, 1995). Additionally, Clayton (1997) recommended that expert panel members are primarily from a homogenous population or discipline, with a few possible representatives from other social or professional stratifications. Although there is no set guideline on the panel size within the Delphi method, there are some guidelines that can be followed. It is recommended that studies consist of no fewer than ten panelists and no more than 25-30, as new information is rarely generated beyond that threshold (Brooks, 1979; Delbecq \& Van de Ven A, 1975; Parentè \& Anderson-Parentè, 1987).

To effectively address this issue, the Delphi panel included individuals with expertise in higher education leadership. A group of 20 experts was purposively selected based on the following level of expertise: higher education kinesiology leaders who at the time of the study were employed by member departments of the American Kinesiology Association (AKA). This criterion was established based on the fact that AKA is a leading association within the field of kinesiology that continually strives to advance the development of all academic interests, research opportunities, and professional development for all fields under the greater kinesiology umbrella (American Kinesiology Association, 2019). The panel included department chairs/heads $(n=15)$, directors $(n=3)$, associate Deans $(n=1)$, and Deans $(n=1)$. The panelists comprised of nine females and 11 males, with an average of 21.5 years of higher education experience. All panelists had knowledge of revenue streams and program implementation within their department.

This research study involved a two-round modified Delphi method to determine consensus related to the impact and feasibility of entrepreneurial initiatives in higher education kinesiology. The literature related to the method states that two rounds are adequate to provide 
convergence of panel response (Lanford, 1972; Murry \& Hammons, 1995). During each round of questioning, the panel members were required to rate a series of entrepreneurial initiatives on impact and feasibility. For this study, entrepreneurial initiative referred to an innovative or experimental new initiative that is intended to facilitate responsible change. Impact referred to the panel member's expected effect of an item as it relates to facilitating change. Feasibility referred to the state or degree of an item to be easily or conveniently implemented. During the second round, the panel members were also asked to provide facilitators or barriers that may influence the implementation of an entrepreneurial initiative.

Delphi panel members were invited to participate in the study through a pre-notification email. The email described (a) the purpose of the study, (b) why the participant was chosen, (c) an explanation of the Delphi Method, (d) an explanation of time requirements, (d) researcher contact information, and (e) a link to a demographic survey (see Appendix D). If the recipients of the email agreed to participate, they completed the attached demographic survey, which also included a recruitment advertisement, consent form, employment-related questions, and a space for other recommended panelists. The lead researcher also used additional emails to answer any concerns from the prospective panel members and to reiterate the significance of their potential contribution to the study. The initial potential participant pool consisted of 127 higher education kinesiology leaders. Prospective members were contacted until 20 qualified experts agreed to serve on the Delphi panel.

Due to the voluntary nature of participation throughout multiple rounds of data collection, participant attrition is a primary concern of the Delphi method (Bulger \& Housner, 2007). As a result of this concern, there were continual follow-up emails sent to panel members throughout each round of the investigation. Based on recommendations from the literature, a 
preset experimental mortality standard was established to determine any detrimental effects that participant attrition may have on the results of the study (Bulger \& Housner, 2007). For this study, the results would have been deemed compromised if there was a more than $20 \%$ attrition rate with the panel members between Round 1 and Round 2 questionnaires. Although participation varied between the rounds, the lowest participation rate (17 out of 20-panel members) still exceeded this predetermined recommendation; therefore, participant attrition was not considered to be a negative factor.

\section{Instrumentation}

The identification of high impact and highly feasible entrepreneurial initiatives that can be implemented in higher education kinesiology departments represented the primary objective of this Delphi investigation. The instrument used was derived from a variety of sources related to academic entrepreneurship, including resources from the Educational Advisory Board (2013) and current discussions within higher education kinesiology leadership (AKA, 2016a, 2016b). These entrepreneurial initiatives were grouped into the following general categories developed by the Education Advisory Board (2013): (a) student recruitment, (b) summer and intersession blended learning, (c), distance learning articulation agreements, (d) distance learning course licensing, (e) applied and professional master's, (f) customized corporate training, (g) seniors' enrichment programs, (h) testing and certification, (i) faculty consulting, and (j) community partnerships. While the Delphi panel members were being recruited for participation in the investigation, a draft of the questionnaire items was designed, and pilot tested.

Instrument design. A panel of five reviewers with demonstrated expertise in the areas of innovation and academic entrepreneurship was purposively selected to evaluate the initial questionnaire items for content validity and completeness. The reviewers were asked to rate the 
content validity of 65 entrepreneurial initiatives using a five-point Likert scale. A group mean rating of four or higher indicated that the item was a valid entrepreneurial initiative that could potentially be implemented within a higher education kinesiology department and, therefore, should be included in the final instrument. Items rated a group mean of three were classified as neutral or undecided and also included in the final instrument. Any item with a group mean rating of a two or lower was eliminated from the final instrument because it lacked validity. Respondents were also requested to add any items that provided more content validity, keeping in mind the goal of producing a comprehensive list of high impact and highly feasible entrepreneurial initiatives for higher education kinesiology departments to implement.

The data collected throughout the pilot study were used to establish a list of entrepreneurial initiatives to be included in the final version of the questionnaire using the following criteria: (a) The item received a mean rating of at least three or higher in the area of content validity, and (b) at least half of the reviewers ranked the item as a three or higher. Only three items failed to meet these criteria and were not included in the final instrument. The eliminated items were categorized as student recruitment efforts, summer and intersession blending learning opportunities, and applied and professional master's programs. If anyone expert reviewer recommended the addition of a new entrepreneurial initiative, it was added to the final version of the survey in the interest of compiling the most inclusive list possible. A total of 38 new items were added to the initial list based on the reviewer's recommendations. These additions related to the following categories: student recruitment, summer, and intersession blended learning, distance learning articulation agreements, applied and professional master's, customized corporate training and partnerships, seniors' enrichment programs, testing and certification, and community partnerships. 
The resulting 100 items were organized into a questionnaire format that required the Delphi panel members to rate each item regarding its impact and feasibility of implementation in a higher education kinesiology setting. Each item's importance was rated using modified versions of two established five-point Likert scales (Vagias, 2006). The level of impact consisted of the following ratings: (5) extremely impactful, (4) very impactful, (3) somewhat impactful, (2) slightly impactful, (1) not at all impactful. The determination of feasibility consisted of the following ratings: (5) extremely feasible, (4) very feasible, (3) somewhat feasible, (2) slightly feasible, (1) not at all feasible. In addition to rating the 100 items in the round one questionnaire, panel members could add any items they saw as valid to the content. Two additional items were added and categorized as testing and certification opportunities that would be rated during the second round. An additional section was added to the Round 2 questionnaire that requested the panel members to provide facilitators or barriers that may influence entrepreneurial initiatives implementation.

\section{Administrative Procedures}

The administrative procedures described in this section have been adapted from the generalized research protocol described by Bulger and Housner (2007). These administrative procedures are described in the following sections: (a) Round 1 Procedures, (b) Round 2 Procedures, and (c) Data Management.

Round 1 procedures. After the approval of the West Virginia University Institutional Review Board (IRB) was obtained, the survey instrument was finalized, and the selection of panelists was completed, each panel member received the first questionnaire via email (see Appendix H). This email included (a) words of gratitude for agreeing to participate in the survey, (b) a restatement of the purpose and rationale of the study, (c) an explanation of the panelists' 
rights and responsibilities, (d) instructions for completing the questionnaire, (e) a hyperlink to the Qualtrics survey instrument (see Appendix I), and (f) contact information for the primary researcher.

Two weeks after the invitation to Round 1 email was sent, each Delphi panel member who had not completed the survey received a follow-up email to confirm receipt of the email, answer any remaining questions, and prompt a timely return of the questionnaire. The panelists who still failed to respond after the first follow-up were contacted once more for the same purposes and to reiterate the importance of their participation. Four-weeks after the initial email, the responses from the Round 1 questionnaire were collected and downloaded into an Excel file. At that time, the group mean scores were calculated for each item.

Round 2 procedures. The second round of questioning followed the same protocols described in the previous section. This email included (a) words of gratitude for agreeing to participate in the survey, (b) instructions for completing the questionnaire, (c) an explanation of the panelists' rights and responsibilities and (d) a hyperlink to the second-round questionnaire (see Appendices $\mathrm{K}$ and L). As part of the second-round instrument, panelists also received both their individual and group mean ratings from the previous round. Any panel member who did not complete the round 1 survey in the allotted period, was only provided with the group means of round one (Appendix M). One panel member had requested to opt-out of the survey after round 1 and was not included in the second-round distribution. Therefore there were only 19-panel members contacted during round 2. Panel members were asked to reevaluate their Round 1 responses in relation to the mean group ratings for each questionnaire item. The protocols for the return, feedback, follow-up for non-completers, and data recording were identical to those described in the Round 1 procedures. An additional section was added to the second-round 
questionnaire that requested panel members to list any facilitators and barriers that may impact the implementation of entrepreneurial initiatives.

An essential last step in the Delphi research process was to send a final research report to all panel members following the return of the Round 2 questionnaires and completion of data analysis. The panel members were also thanked for providing their time and expertise throughout the research process.

Data management. One key advantage of the Delphi method is that panelists remain anonymous to all other participants, which can prevent group pressure, untruthful responses, or dominance by influential individuals (Sandrey \& Bulger, 2008). To maintain anonymity and avoid bias, all panelists were de-identified and assigned an individual and unique code that allowed only the research to access their details. All identifying information (name, contact information, demographics) was kept confidential and not shared with other participants. All demographic information was used only to ensure panelists met the participation inclusion criteria or for drawing anonymous references after the study.

\section{Data Analysis}

One of the most valuable aspects of the Delphi Method is its ability to generate ideas for solutions to complex issues and problems (Bulger \& Housner, 2007). Based on this premise, the expected outcomes for this research included the generation of a list of entrepreneurial initiatives this panel of experts regarded worth implementing in higher education kinesiology programs. Additionally, the expert panel members were asked to recommend facilitators and barriers that may impact the implementation of any initiatives.

Entrepreneurial initiatives. The data collected during the second round of the study were used to provide a final measure of consensus regarding the impact and feasibility of each 
entrepreneurial initiative. For this study, an item needed to be considered both impactful and feasible to be considered worthy of implementation. Any item's impact and feasibility that was rated equal to or higher than 3.19 and 3.02, respectively, were considered most impactful and feasible. Ordered pair data were graphed on an $X Y$ scatterplot matrix to depict the relationships between the variables visually, the group means used to determine relative ratings, and overall item placement (see Figure 1).

Facilitators and barriers. During the second round of the Delphi, the panel members were also asked to list any facilitators or barriers that may impact the implementation of the provided EIs. Based on the vagueness of the responses as a whole and the qualitative data lacking in overall richness, the primary researcher analyzed the qualitative data through basic descriptive coding techniques. Each open-ended response was summarized in one word that captured the substance of the message (Tesch, 1990). Once the codes were established, an independent rater applied these codes to the same data and categorized each facilitator and barrier. The independent rater did not introduce any additional codes. A point-by-point agreement ratio (Kazdin, 2011) of $87.80 \%$ was established between the primary researcher and independent rater ([agreement / (agreements + disagreements) x 100).

\section{Results}

Of the 102 items evaluated by the expert panelists during the final round, 44 EIs were rated as both high impact and high feasibility (see Figure 1). These items, deemed most worthy of implementation, were rated above average in both terms of impact and feasibility, these fell in the green "go-zone." These items received a consensus that they were worth taking action on soon to increase revenue. Out of the ten highest-rated items on either rating scale, five were rated as both impact and feasibility, including experiential learning opportunities, enhanced website 
content, co-ops/internship placements, expedited admissions decisions, and current student and recent graduate referral programs. Other worthy endeavors can be seen in the two yellow quadrants. These items were rated as either highly impactful or feasible, but not both, and therefore are worth consideration based on the environment. The final quadrant is the red zone, which includes all items that were rated below average for impact and feasibility and, therefore, not worth implementation.

\section{Figure 1. Individual Entrepreneurial Initiative Items}

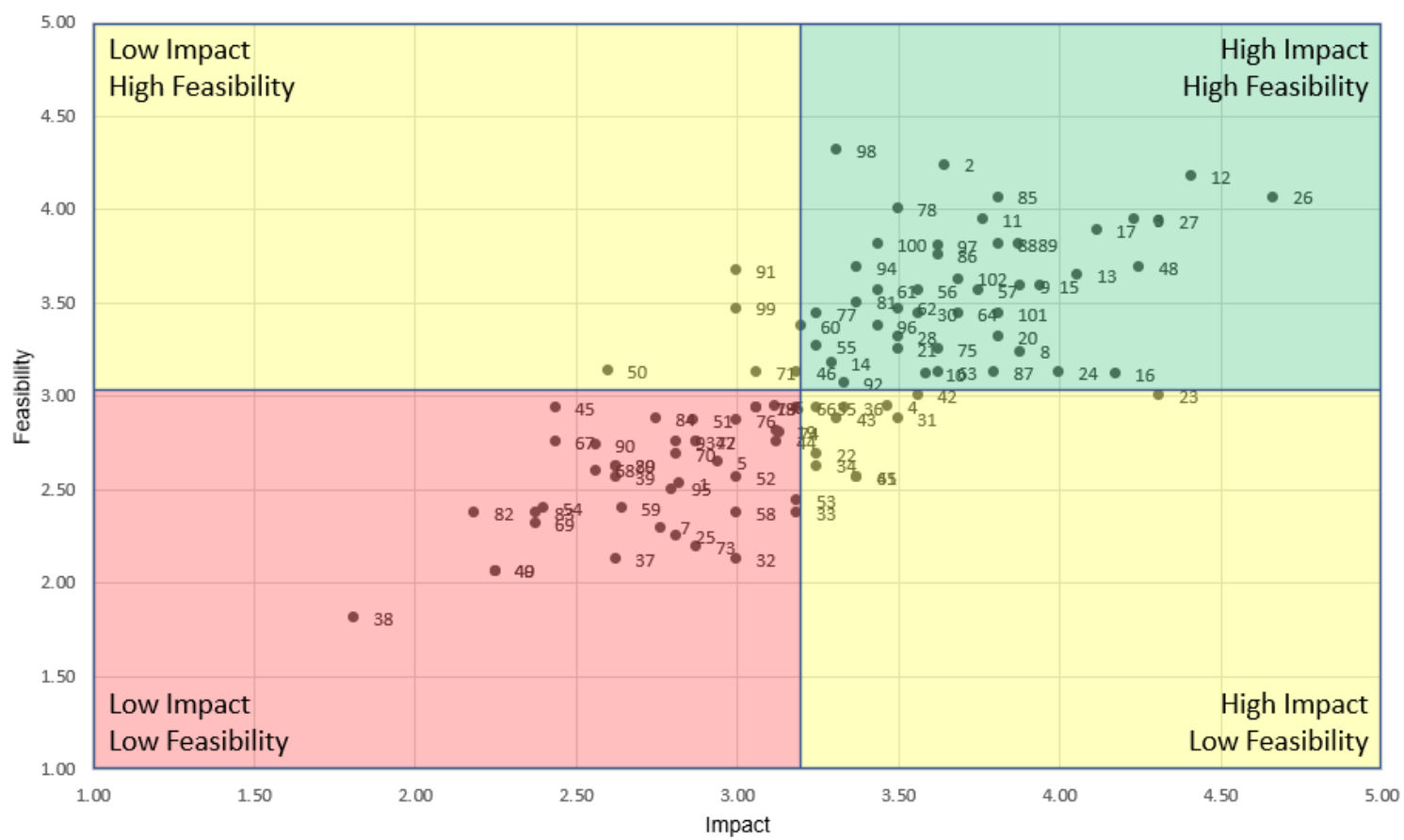

Figure 1. Visual representation of the placement of items based on the average rating of impact and feasibility. The graph is divided into four zones that are indicative of the worthiness of implementation in departmental contexts.

In Figure 2, the items are consolidated based on the categories used to organize the survey with five rated as most impactful and feasible: Community Partnerships (CP), Student Recruitment (SR), Summer and Intersession Blending Leading (SIBL), Testing and Certification (TC), and Customized Corporate Training and Partnerships (CCTP). Distance Learning 
Articulation Agreements (DLAA) rated above average on impact only, and Faculty Consulting (FC) rated above average on feasibility but not impact. Three categories were below the relative criteria for consensus on both rating scales: Seniors' Enrichment Programs (SEP), Applied and Professional Master's (APM), and Distance Learning Course Licensing (DLCL). The results of each of these categories are discussed in further detail in the following sections.

Figure 2. Entrepreneurial Initiative Item Group Averages

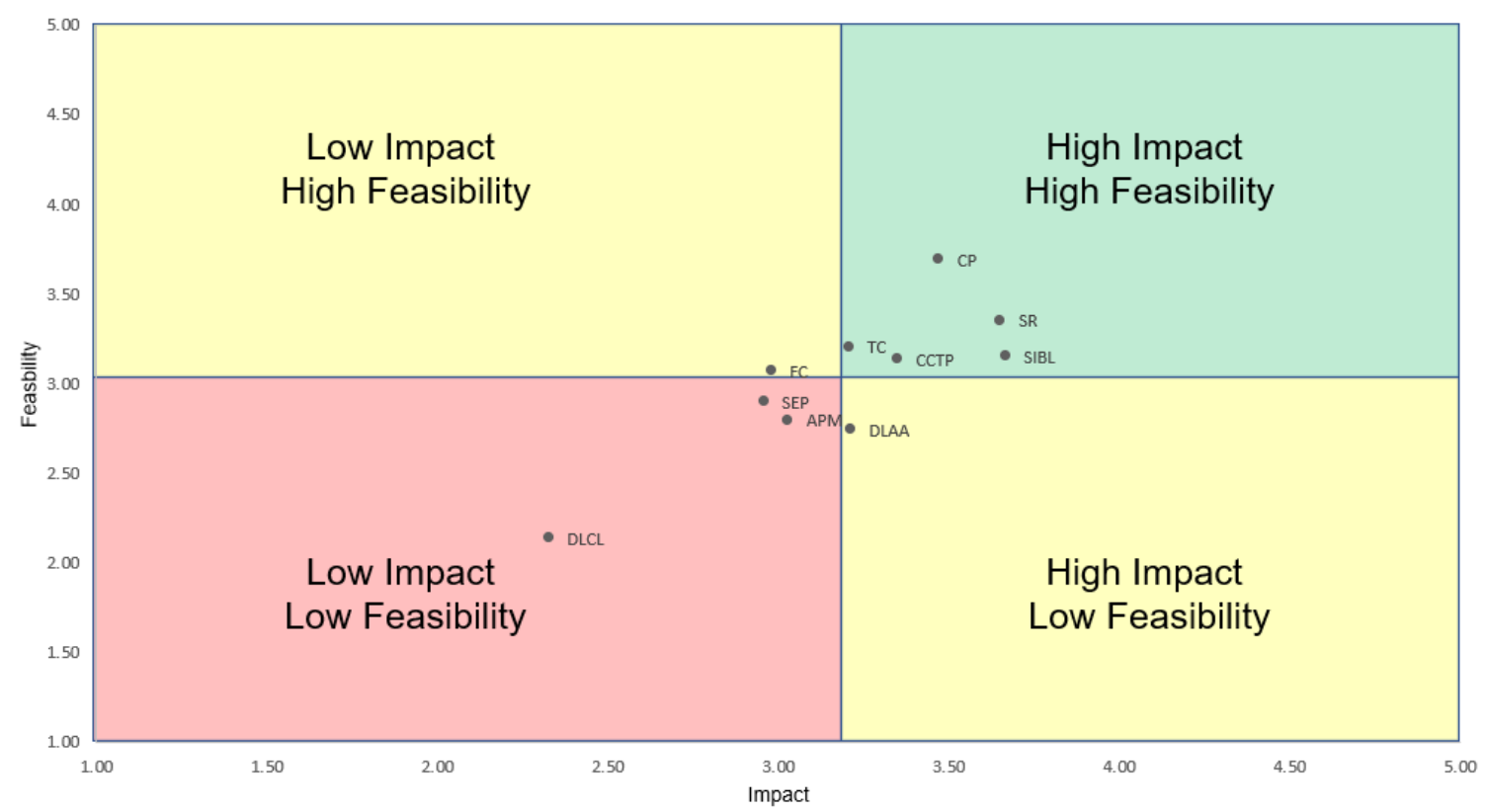

Figure 2. Graph displays where group averages rate in relation to impact and feasibility averages. Quadrants or zones depicted are divided by the same means used in the individual items graph.

\section{Student Recruitment}

Delphi panel members reached a consensus of agreement regarding 12 of the 17 student recruitment related items (see Table 1). These items had the second highest mean impact and feasibility ratings at 3.65 and 3.35 , respectively. The EIs considered to be most actionable were: (a) enhanced website content, (b) expedited admissions decisions, and (c) current student and recent graduate referral programs, which all received a combined rating of four or higher. Seven items met the criteria for consensus with a combined mean rating of 3.5 to 4.0 as well: (a) 
master's by coursework, (b) consumer-targeted social media recruitment strategies, (c) targeted video and digital marketing campaigns, (d) explicit career pathways and experiential learning opportunities, (e) enrollment/recruitment coaching, (f) unique scholarship opportunities, and (g) customizable degree programs. An additional two EIs in-house recruiter/enrollment specialist and intentional lead generation efforts met the criteria for consensus by surpassing the relative mean average. One item, guided pathway programs for international populations, satisfied the criteria for impact but was not considered feasible for implementation. Four EIs in this category failed to meet the criteria for consensus: (a) use of community college recruiting teams, (b) young professionals condensed ESL programs, (c) third-party recruiting agents, and (d) foreignborn faculty-student recruitment trips.

Table 1 Student Recruitment

\begin{tabular}{|c|c|c|c|c|c|}
\hline \multirow[b]{2}{*}{ No. } & \multirow[b]{2}{*}{ Item } & \multicolumn{2}{|c|}{ Impact } & \multicolumn{2}{|c|}{ Feasibility } \\
\hline & & $M$ & $S D$ & $M$ & $S D$ \\
\hline 1. & Third-party recruiting agents & 2.82 & 0.86 & 2.53 & 0.78 \\
\hline 2. & Master's by coursework ${ }^{*}$ & 3.65 & 0.84 & 4.24 & 0.73 \\
\hline 3. & Expedited admissions decisions ${ }^{*}$ & 4.24 & 0.64 & 3.94 & 0.73 \\
\hline 4. & $\begin{array}{l}\text { Guided pathways for international } \\
\text { populations }\end{array}$ & 3.47 & 0.85 & 2.94 & 0.73 \\
\hline 5. & $\begin{array}{l}\text { Young professional condensed ESL } \\
\text { programs }\end{array}$ & 2.94 & 1.00 & 2.65 & 0.68 \\
\hline 6. & Use of community college recruiting teams & 3.12 & 1.18 & 2.94 & 1.06 \\
\hline 7. & $\begin{array}{l}\text { Foreign-born faculty student recruitment } \\
\text { trips }\end{array}$ & 2.76 & 1.06 & 2.29 & 0.89 \\
\hline 8. & Customizable degree programs ${ }^{*}$ & 3.88 & 1.08 & 3.24 & 1.06 \\
\hline 9. & Enrollment/Retention Coaching* & 3.88 & 0.96 & 3.59 & 1.03 \\
\hline 10. & In-house recruiter/enrollment specialist ${ }^{*}$ & 3.59 & 0.91 & 3.12 & 0.90 \\
\hline 11. & $\begin{array}{l}\text { Consumer-targeted social media recruitment } \\
\text { strategies }\end{array}$ & 3.76 & 0.73 & 3.94 & 0.80 \\
\hline 12. & Enhanced website content ${ }^{*}$ & 4.41 & 0.69 & 4.18 & 0.71 \\
\hline
\end{tabular}




\begin{tabular}{|c|c|c|c|c|c|}
\hline 13. & $\begin{array}{l}\text { Targeted video and digital marketing } \\
\text { campaigns* }\end{array}$ & 4.06 & 0.80 & 3.65 & 0.59 \\
\hline 14. & Intentional lead generation efforts & 3.29 & 0.89 & 3.18 & 0.86 \\
\hline 15 . & $\begin{array}{l}\text { Explicit career pathways and experiential } \\
\text { learning opportunities* }\end{array}$ & 3.94 & 0.94 & 3.59 & 0.91 \\
\hline 16. & Unique scholarship strategies ${ }^{*}$ & 4.18 & 0.78 & 3.12 & 0.90 \\
\hline 17. & $\begin{array}{l}\text { Current student and recent graduate referral } \\
\text { programs }\end{array}$ & 4.12 & 0.68 & 3.88 & 0.58 \\
\hline
\end{tabular}

\section{Summer and Intersession Blended Learning}

In total, six of the 11 summer and intersession blended learning items met the criteria for consensus, with an average impact rating of 3.67 and feasibility of 3.15 (see Table 2). This was the highest impact and fourth-highest feasibility of all the categories. The EIs considered to be most worthy of implementation in this category were: experiential learning opportunities and coops/internship placements, which both received a combined rating of four or higher. There were an additional four EIs that met the criteria for consensus: (a) high-demand major prerequisite summer sessions, (b) general education requirement blended courses, (c) specialized events for current students and recent alumni and (d) independent study summer sessions.

Two EIs, summer and intersession financial aid and open enrollment intersession courses, satisfied the criteria for impact but were not considered feasible for implementation. Less agreement was obtained on the remaining three EIs, which failed to meet the criteria for consensus regarding impact or feasibility: (a) extended stay summer term, (b) oversubscribed course summer sessions, and (c) study abroad makeup courses. 
Table 2 Summer and Intersession Blended Learning

\begin{tabular}{|c|c|c|c|c|c|}
\hline \multirow[b]{2}{*}{ No. } & \multirow[b]{2}{*}{ Item } & \multicolumn{2}{|c|}{ Impact } & \multicolumn{2}{|c|}{ Feasibility } \\
\hline & & $M$ & $S D$ & $M$ & $S D$ \\
\hline 18. & Extended stay summer term & 3.06 & 0.75 & 2.94 & 0.90 \\
\hline 19. & Oversubscribed course summer sessions & 3.13 & 0.99 & 2.81 & 0.95 \\
\hline 20. & $\begin{array}{l}\text { High-demand major prerequisite summer } \\
\text { sessions }\end{array}$ & 3.81 & 0.73 & 3.31 & 0.85 \\
\hline 21. & Independent study summer sessions ${ }^{*}$ & 3.50 & 0.79 & 3.25 & 0.83 \\
\hline 22. & Open enrollment intersession courses & 3.25 & 0.90 & 2.69 & 0.77 \\
\hline 23. & Summer and intersession financial aid & 4.31 & 0.58 & 3.00 & 1.00 \\
\hline 24. & $\begin{array}{l}\text { General education requirement blended } \\
\text { courses }\end{array}$ & 4.00 & 0.87 & 3.13 & 0.99 \\
\hline 25. & Study abroad makeup courses & 2.81 & 0.88 & 2.25 & 0.66 \\
\hline 26. & Experiential learning opportunities* & 4.67 & 0.47 & 4.06 & 1.09 \\
\hline 27. & Co-ops/internship placements ${ }^{*}$ & 4.31 & 1.04 & 3.93 & 1.06 \\
\hline 28. & $\begin{array}{l}\text { Specialized events for current students and } \\
\text { recent alumni* }\end{array}$ & 3.50 & 0.71 & 3.31 & 0.58 \\
\hline
\end{tabular}

\section{Distance Learning Articulation Agreements}

The Delphi panelists reached a consensus of agreement regarding one of the eight distance learning articulation agreements related to entrepreneurial (see Table 3). The mean rating for impact 3.21 and feasibility 2.74 was the fifth-highest and second-lowest ratings of all the categories. The only EI that met the full criteria for consensus was blended courses/programs.

Four EIs, (a) online dual enrollment programs, (b) online employment skills certificate programs, (c) international partnerships, and (d) international institution graduate partnerships, satisfied the criteria for impact but were not considered feasible. The remaining three items articulations with private companies/organizations, out of state community online college 
programs, and dual-degree programs with other universities, failed to meet the criteria for consensus regarding either variable.

Table 3 Distance Learning Articulation Agreements

\begin{tabular}{|c|c|c|c|c|c|}
\hline \multirow[b]{2}{*}{ No. } & \multirow[b]{2}{*}{ Item } & \multicolumn{2}{|c|}{ Impact } & \multicolumn{2}{|c|}{ Feasibility } \\
\hline & & $M$ & $S D$ & $M$ & $S D$ \\
\hline 29. & Out of state community college programs & 2.63 & 1.05 & 2.63 & 0.86 \\
\hline 30. & Blended courses/programs* & 3.56 & 0.93 & 3.44 & 0.86 \\
\hline 31. & Online dual enrollment programs & 3.50 & 1.06 & 2.88 & 0.93 \\
\hline 32. & $\begin{array}{l}\text { Dual-degree programs with other } \\
\text { universities }\end{array}$ & 3.00 & 0.87 & 2.13 & 0.86 \\
\hline 33. & $\begin{array}{l}\text { Articulations with private } \\
\text { companies/organizations }\end{array}$ & 3.19 & 1.07 & 2.38 & 0.78 \\
\hline 34. & $\begin{array}{l}\text { International institution graduate } \\
\text { partnership agreements }\end{array}$ & 3.25 & 0.97 & 2.63 & 0.60 \\
\hline 35. & International partnerships & 3.25 & 0.97 & 2.94 & 0.75 \\
\hline 36. & $\begin{array}{l}\text { Online employment skills certificate } \\
\text { programs }\end{array}$ & 3.33 & 0.87 & 2.94 & 0.83 \\
\hline
\end{tabular}

*Item met the criteria for consensus including the required mean rating for both impact and feasibility

\section{Distance Learning Course Licensing}

Panel members failed to reach a consensus of agreement on any of the distance learning course licensing items (see Table 4). This category had the lowest mean impact and feasibility ratings of 2.33 and 2.14, respectively. The four EIs that failed to meet the criteria for consensus were: (a) recreational learning brand licensing, (b) turnkey homeschool curriculum, (c) capstone case study sales, and (d) international course sales.

Table 4 Distance Learning Course Licensing

\begin{tabular}{ccllll}
\hline & & \multicolumn{2}{c}{ Impact } & \multicolumn{2}{c}{ Feasibility } \\
\cline { 3 - 6 } No. & Item & $\boldsymbol{M}$ & $\boldsymbol{S D}$ & $\boldsymbol{M}$ & $\boldsymbol{S D}$ \\
\hline 37. & Recreational learning brand licensing & 2.63 & 0.78 & 2.13 & 0.78
\end{tabular}


38. Turnkey homeschool curriculum

$1.81 \quad 0.63$

1.81

0.81

39. Capstone case study sales

$\begin{array}{llll}2.63 & 0.93 & 2.56 & 0.93\end{array}$

40. International course sales

$\begin{array}{lll}2.25 & 0.97 \quad 2.06\end{array}$

0.75

*No items in this category met the criteria for consensus including the required mean rating for both impact and feasibility

\section{Applied and Professional Master's}

Only one of the 14 EIs related to applied and professional master's programs reached the criteria for consensus (see Table 5). Overall, the average rating for impact and feasibility of the student recruitment EIs was 3.03 and 2.80, respectively. This was the fourth lowest impact and third-lowest feasibility of all the categories included in the questionnaire. The EI considered to be most actionable was accelerated degree programs. There were three EIs that satisfied the criteria for impact, but not considered feasible for implementation: (a) professional science master's, (b) interdisciplinary terminal master's, and (c) on-demand new cohort programs. Inversely, two EIs met the criteria for consensus regarding impact but fell short of consensus related to feasibility: (a) stackable certificates and (b) digital badging. Less agreement was obtained on the remaining eight EIs, which failed to meet the criteria for consensus regarding impact or feasibility: (a) weekend course master's, (b) employee-based cohorts, (c) new regulatory requirement certificates, (d) flexible term start, (e) discounting pricing for professional-based cohorts, (f) applied liberal arts master's, (g) fully online lifetime portfolios, and (h) micro-credentialing and nano degrees.

\section{Table 5 Applied and Professional Master's}

\begin{tabular}{cccccc}
\hline & & \multicolumn{2}{c}{ Impact } & \multicolumn{2}{c}{ Feasibility } \\
\cline { 3 - 6 } No. & Item & $\boldsymbol{M}$ & $\boldsymbol{S D}$ & $\boldsymbol{M}$ & $\boldsymbol{S D}$ \\
\hline 41. & On-demand new cohort programs & 3.38 & 0.93 & 2.56 & 0.93 \\
42. & Professional science master's & 3.56 & 0.86 & 3.00 & 0.94 \\
43. & Interdisciplinary science master's & 3.31 & 0.98 & 2.88 & 0.99
\end{tabular}




\begin{tabular}{|c|c|c|c|c|}
\hline Weekend course master's & 3.13 & 1.11 & 2.75 & 1.20 \\
\hline Applied liberal arts master's & 2.44 & 0.93 & 2.94 & 1.14 \\
\hline Stackable certificates & 3.19 & 1.18 & 3.13 & 1.11 \\
\hline New regulatory requirements certificates & 2.88 & 0.93 & 2.75 & 0.83 \\
\hline Accelerated degree programs ${ }^{*}$ & 4.25 & 0.56 & 3.69 & 0.77 \\
\hline Micro-credentialing and nano degrees & 2.25 & 1.15 & 2.06 & 0.75 \\
\hline Digital badging & 2.60 & 0.95 & 3.13 & 1.09 \\
\hline Employee-based cohorts & 2.87 & 1.15 & 2.87 & 1.15 \\
\hline $\begin{array}{l}\text { Discounting pricing for professional based } \\
\text { cohorts }\end{array}$ & 3.00 & 1.12 & 2.56 & 1.00 \\
\hline Flexible term start & 3.19 & 1.13 & 2.44 & 0.93 \\
\hline Fully online lifetime portfolios & 2.40 & 0.95 & 2.40 & 1.02 \\
\hline
\end{tabular}

*Item met the criteria for consensus including the required mean rating for both impact and feasibility

\section{Customized Corporate Training and Partnerships}

Three-quarters (eight of 12) of the customized corporate training and partnership items reached a consensus of agreement and met the criteria for inclusion (see Table 6). This category had the fourth-highest impact rating at 3.35 and fifth-highest feasibility at 3.14 . In this category, the items considered to be most actionable were: (a) after-hours course scheduling, (b) online professional master's, (c) continuing professional development for corporations, and (d) referral programs of potential employers for program graduates. There were also an additional four EIs that met the criteria for consensus with a combined mean rating below 3.5: (a) partnerships with non-profits and professional associations needing continuing education, (b) corporate initiatives to identify and fund under-served populations, (c) corporate advisory committees, and (d) career path maps.

Two EIs satisfied the criteria for impact but was not considered feasible for implementation in higher education kinesiology recognition of company training as being degree pursuant, and tuition breaks for partnering companies. The two remaining EIs failed to meet the 
criteria for impact or feasibility: rapid-cycle customized curriculum and templatized company policies.

Table 6 Customized Corporate Training and Partnerships

\begin{tabular}{|c|c|c|c|c|c|}
\hline \multirow[b]{2}{*}{ No. } & \multirow[b]{2}{*}{ Item } & \multicolumn{2}{|c|}{ Impact } & \multicolumn{2}{|c|}{ Feasibility } \\
\hline & & $M$ & $S D$ & $M$ & $S D$ \\
\hline 55. & Career path maps ${ }^{*}$ & 3.25 & 1.09 & 3.27 & 1.00 \\
\hline 56. & Online professional master's* & 3.56 & 0.86 & 3.56 & 1.17 \\
\hline 57. & After-hours course scheduling ${ }^{*}$ & 3.75 & 0.56 & 3.56 & 1.12 \\
\hline 58. & Rapid-cycle customized curriculum & 3.00 & 1.10 & 2.38 & 0.78 \\
\hline 59. & Templatized company policies & 2.64 & 1.17 & 2.40 & 0.80 \\
\hline 60. & Corporate advisory committees ${ }^{*}$ & 3.20 & 1.05 & 3.38 & 1.17 \\
\hline 61. & $\begin{array}{l}\text { Referral programs of potential employers } \\
\text { for program graduates }\end{array}$ & 3.44 & 1.17 & 3.56 & 0.93 \\
\hline 62. & $\begin{array}{l}\text { Partnerships with non-profits and } \\
\text { professional associations needing } \\
\text { continuing education* }\end{array}$ & 3.50 & 1.00 & 3.47 & 0.81 \\
\hline 63. & $\begin{array}{l}\text { Corporate initiatives to identify and fund } \\
\text { under-served populations }\end{array}$ & 3.63 & 1.22 & 3.13 & 1.05 \\
\hline 64. & $\begin{array}{l}\text { Continuing professional development for } \\
\text { corporations }\end{array}$ & 3.69 & 0.85 & 3.44 & 0.86 \\
\hline 65. & Tuition breaks for partnering companies & 3.38 & 1.17 & 2.56 & 0.86 \\
\hline 66. & $\begin{array}{l}\text { Recognition of company training as being } \\
\text { degree pursuant }\end{array}$ & 3.19 & 1.18 & 2.94 & 1.25 \\
\hline
\end{tabular}

*Item met the criteria for consensus including the required mean rating for both impact and feasibility

\section{Seniors’ Enrichment Programs}

The senior's enrichment programs category only had three of 12 items meet consensus (see Table 7). Both the impact and feasibility ratings were below average at 2.96 and 2.90, respectively. These ratings were the second and fourth-lowest of all the categories included in the survey. The items in this category considered to be most worthy of implementation based on the combined mean rating of impact and feasibility were: (a) themed yearly lecture series, (b) 
sport and eco-tourism approaches, and (c) enrichment courses. Faculty-led destination travel satisfied the criteria for feasibility but was not considered impactful. Less agreement was obtained on the remaining eight EIs, all of which failed to meet the criteria for consensus: (a) multi-generational activities, (b) faculty-led inter-generational study abroad, (c) Osher lifelong learning grants, (d) local excursion weekends, (e) couples' memberships, (g) expanded course audit catalogs, (h) college-affiliated retirement communities, and (i) priced-to-market course audit fees.

\section{Table 7 Seniors' Enrichment Programs}

\begin{tabular}{|c|c|c|c|c|c|}
\hline \multirow[b]{2}{*}{ No. } & \multirow[b]{2}{*}{ Item } & \multicolumn{2}{|c|}{ Impact } & \multicolumn{2}{|c|}{ Feasibility } \\
\hline & & $M$ & $S D$ & $M$ & $S D$ \\
\hline 67. & Couples' membership & 2.44 & 1.00 & 2.75 & 1.09 \\
\hline 68. & Expanded course audit catalogs & 2.56 & 1.06 & 2.60 & 1.14 \\
\hline 69. & Priced-to-market course audit fees & 2.38 & 1.22 & 2.31 & 1.04 \\
\hline 70. & Local excursion weekends & 2.81 & 1.29 & 2.69 & 0.92 \\
\hline 71. & Faculty-led destination travel & 3.06 & 1.30 & 3.13 & 1.11 \\
\hline 72. & Osher lifelong learning grants & 2.88 & 1.17 & 2.75 & 0.97 \\
\hline 73. & College-affiliated retirement communities & 2.88 & 1.22 & 2.19 & 0.63 \\
\hline 74. & Multi-generational activities & 3.13 & 1.02 & 2.80 & 0.98 \\
\hline 75. & Sport and eco-tourism approaches ${ }^{*}$ & 3.63 & 1.05 & 3.25 & 0.97 \\
\hline 76. & $\begin{array}{l}\text { Faculty led inter-generational study abroad } \\
\text { trips }\end{array}$ & 3.00 & 0.89 & 2.87 & 0.96 \\
\hline 77. & Enrichment courses ${ }^{*}$ & 3.25 & 0.90 & 3.44 & 0.79 \\
\hline 78. & Themed yearly lecture series ${ }^{*}$ & 3.50 & 0.87 & 4.00 & 0.87 \\
\hline
\end{tabular}

*Item met the criteria for consensus including the required mean rating for both impact and feasibility

\section{Testing and Certifications}

Delphi members reached a consensus of agreement on six of the 11 testing and certification items (see table 8). The impact rating was the fifth-lowest (3.21), while the 
feasibility rating was the third-highest (3.20) for this category. The following EIs were rated as the most worthy of implementation: (a) coaching certification programs, (b) exercise prescription, (c) exercise testing, and (d) building testing and testing preparation into the curriculum. Two additional items met the criteria for consensus but with lower mean ratings, diagnostic testing in clinical settings, and distance learning proctoring services. The remaining EIs failed to meet the criteria for consensus regarding impact or feasibility: (a) professional society testing partnerships, (b) online remedial programs, (c) ESL testing and certification, (d) for-profit educator testing site rental, and (e) placement test fee.

\section{Table 8 Testing and Certifications}

\begin{tabular}{|c|c|c|c|c|c|}
\hline \multirow[b]{2}{*}{ No. } & \multirow[b]{2}{*}{ Item } & \multicolumn{2}{|c|}{ Impact } & \multicolumn{2}{|c|}{ Feasibility } \\
\hline & & $M$ & $S D$ & $M$ & $S D$ \\
\hline 79. & Professional society testing partnerships & 3.06 & 0.97 & 2.94 & 0.83 \\
\hline 80. & ESL testing and certification & 2.63 & 0.93 & 2.63 & 0.93 \\
\hline 81. & Distance learning proctoring services* & 3.38 & 0.93 & 3.50 & 0.87 \\
\hline 82. & Placement test fee & 2.19 & 0.88 & 2.38 & 0.99 \\
\hline 83. & For-profit educator testing site rental & 2.38 & 0.86 & 2.38 & 0.70 \\
\hline 84. & Online remedial programs & 2.75 & 1.20 & 2.88 & 1.11 \\
\hline 85. & Coaching certification programs ${ }^{*}$ & 3.81 & 0.95 & 4.06 & 1.03 \\
\hline 86. & $\begin{array}{l}\text { Building testing and testing prep into } \\
\text { curriculum* }\end{array}$ & 3.63 & 1.11 & 3.75 & 1.03 \\
\hline 87. & Diagnostic testing in clinical settings ${ }^{*}$ & 3.80 & 0.75 & 3.13 & 0.86 \\
\hline 88. & Exercise testing ${ }^{*}$ & 3.81 & 1.07 & 3.81 & 1.13 \\
\hline 89. & Exercise prescription ${ }^{*}$ & 3.88 & 1.05 & 3.81 & 1.13 \\
\hline
\end{tabular}

\section{Faculty Consulting}

The expert panelists reached a consensus of agreement regarding two of the six faculty consulting related entrepreneurial initiatives (see Table 9). Overall, the average rating for impact 
and feasibility of the faculty consulting EIs was 2.98 and 3.07, respectively. This was the thirdlowest impact and fifth-lowest feasibility of all the categories included in the questionnaire. The EIs in this category considered to be most worthy of implementation based on the combined mean rating of impact and feasibility were: (a) personal training and (b) industry-sponsored capstone projects. One EI, faculty expertise databases, satisfied the criteria for feasibility but was not considered impactful enough for implementation. Less agreement was obtained on the remaining three EIs, which failed to meet the criteria for consensus: (a) nurse practitioner practices, (b) therapy sessions, and (c) international university curriculum consulting.

\section{Table 9 Faculty Consulting}

\begin{tabular}{|c|c|c|c|c|c|}
\hline \multirow[b]{2}{*}{ No. } & \multirow[b]{2}{*}{ Item } & \multicolumn{2}{|c|}{ Impact } & \multicolumn{2}{|c|}{ Feasibility } \\
\hline & & $M$ & $S D$ & $M$ & $S D$ \\
\hline 90. & $\begin{array}{l}\text { International university curriculum } \\
\text { consulting }\end{array}$ & 2.56 & 1.00 & 2.73 & 0.93 \\
\hline 91. & Faculty expertise databases & 3.00 & 0.97 & 3.67 & 0.94 \\
\hline 92. & Industry sponsored capstone projects ${ }^{*}$ & 3.33 & 1.19 & 3.07 & 1.00 \\
\hline 93. & Nurse practitioner practices & 2.81 & 1.29 & 2.75 & 1.09 \\
\hline 94. & Personal training ${ }^{*}$ & 3.38 & 0.99 & 3.69 & 1.04 \\
\hline 95. & Therapy sessions & 2.80 & 0.75 & 2.50 & 1.00 \\
\hline
\end{tabular}

*Item met the criteria for consensus including the required mean rating for both impact and feasibility

\section{Community Partnerships}

The expert panelists reached a consensus of agreement regarding seven of the eight community partnerships items (see Table 10). Overall, the average rating for impact and feasibility of the community partnerships EIs was 3.47 and 3.69, respectively. This was rated the third-highest in impact and the highest feasibility of all the categories. The EIs in this category considered to be most worthy of implementation based on the combined mean rating of impact and feasibility were: (a) community lectures, (b) community activity programs, (c) public school 
career academy partnerships, (d) community/professional association-sponsored

presentations/outreach, and (e) under-served populations focused/incentivized programs. There were an additional EI, summer youth camps, that met the criteria for consensus but with a lower combined mean rating below 3.5. The final item in this category, multi-generational activity opportunities, satisfied the criteria for feasibility but was not considered impactful enough for implementation in higher education kinesiology programs.

Table 10 Community Partnerships

\begin{tabular}{|c|c|c|c|c|c|}
\hline \multirow[b]{2}{*}{ No. } & \multirow[b]{2}{*}{ Item } & \multicolumn{2}{|c|}{ Impact } & \multicolumn{2}{|c|}{ Feasibility } \\
\hline & & $M$ & $S D$ & $M$ & $S D$ \\
\hline 96. & Summer youth camps ${ }^{*}$ & 3.44 & 1.32 & 3.38 & 1.22 \\
\hline 97. & Community activity programs ${ }^{*}$ & 3.63 & 1.05 & 3.80 & 0.83 \\
\hline 98. & Community lectures ${ }^{*}$ & 3.31 & 0.92 & 4.31 & 0.68 \\
\hline 99. & Multi-generational activity opportunities & 3.00 & 1.12 & 3.47 & 1.15 \\
\hline 100. & $\begin{array}{l}\text { Community/professional association } \\
\text { sponsored presentations/outreach }^{*}\end{array}$ & 3.44 & 0.79 & 3.81 & 0.88 \\
\hline 101. & $\begin{array}{l}\text { Under-served populations } \\
\text { focused/incentivized programs* }\end{array}$ & 3.81 & 1.01 & 3.44 & 1.00 \\
\hline 102. & Public school career academy partnerships* & 3.69 & 0.98 & 3.63 & 1.05 \\
\hline
\end{tabular}

*Item met the criteria for consensus including the required mean rating for both impact and feasibility

\section{Effects on Implementation}

During the final round of the survey, the Delphi panel members were asked to list any facilitators or barriers that may impact the implementation of the previously rated EIs within a higher education kinesiology program. The 17 second-round completers provided a total of 42 discrete, 21 facilitators, and 21 barriers, that could potentially impact implementation. These items were sorted into the following themes: support, belief, time, and money. For this study, support related to the culture of the surrounding stakeholders and their ability and interest in supporting entrepreneurial activity. Belief was the understanding that faculty see their roles as 
innovators and need to be focused on entrepreneurship in addition to their more traditional roles of research, teaching, and service. The third theme, time, was the concept that faculty need time designated solely for entrepreneurship in order to be successful. The theme money encompassed any facilitators and barriers that were related to financial measures related to faculty members individually or the institution as a whole.

In total, $35.71 \%$ (15 of 42) of all the responses were related to support factors that may impact the implementation of the identified strategies. The need for support was overwhelmingly present as a necessary facilitator, accounting for almost half of all responses. The lack of support was also identified as a barrier, with 5 of the 21 responses being coded as such. Responses related to beliefs were the second most mentioned by the participating panel members, accounting for 10 of the 42 items. This code accounted for $28.57 \%$ of the facilitators provided and $19.05 \%$ of the barriers. Unlike the previous two codes, time was listed primarily as a negative factor, or barrier, regarding implementation. There were eight (19.05\%) responses that fit into this category. Money was the least mentioned theme, but like time in that, it accounted for slightly more negative responses than positive. Money related considerations accounted for approximately $19.05 \%$ of the barriers provided and only $14.29 \%$ of the facilitators.

\section{Discussion}

While entrepreneurial activity has been researched in higher education, there is far less literature in this area as it relates specifically to kinesiology. Despite that researchers in the field called for the kinesiology academy to become more entrepreneurial for decades (Block \& Estes, 2011; Ellis, 1987), there is still little research providing evidence-informed strategies for moving forward in this area. Although limited in size in scope, this study offers a variety of entrepreneurial initiatives for leaders in higher education who are looking to increase program 
revenue. Using a modified Delphi method consisting of items rated by expert panel members, community partnerships, student recruitment efforts, and summer and intersession blended learning opportunities were found to be the worthiest areas of focus for entrepreneurial activity based on impact and feasibility. Before the implementation of any initiatives, faculty should also thoroughly evaluate the provided facilitators and barriers to gauge how this may impact any entrepreneurial initiative and its opportunity for success.

The highest-rated categories were consistent with what most of the field of higher education kinesiology has already begun to focus their entrepreneurial efforts on. Community partnerships were rated, on average, the most feasible. While many programs and scholars are already active in their greater community through service requirements, the next step would be to identify which of these programs can be implemented using a platform that generates additional program revenue. It must be remembered that moving forward, and higher education can no longer afford only to concern itself with knowledge, but also how marketable that knowledge can be (Welch, 2001). One of the most prominent barriers mentioned in the open-ended responses was time; this category of innovation is particularly feasible because most professionals are already taking time out of their schedules for these items. While not rated extremely high in terms of financial impact, community partnerships are marketable and, more importantly, highly feasible, which may make it possible to begin implementing multiple programs at once. Some examples that kinesiology scholars could start with are community lectures and community activity programs, where professors can charge a minimal fee for the content they are already presenting or implementing daily within their classrooms. As the lines blur between high schools and universities (Block \& Estes, 2011), kinesiology departments should focus on ways to profit from this interdependence. One way to do this would be the implementation of public-school 
career academy partnerships. These initiatives span several areas, and could also serve as a recruitment tool or pathway for early enrollment. This would involve faculty or administrators building more reliable connections with their neighboring school districts to allow students who are in secondary education to begin to explore kinesiology related careers and fields.

Student recruitment has become a primary focus for many institutions as traditional enrollment either remains stagnant or continues to decrease while alternative student populations enter the post-secondary learning process (Hanover Research, 2017). Some of the items related to student recruitment rated the highest in terms of impact and feasibility out of all 102 items provided to the panel. Enhanced website content was the second-highest item of the entire survey and, therefore, should be of immediate concern and focus for programs looking to make new efforts. Potential students are most likely to discover programs and research possibilities through online platforms, and therefore departments need to ensure their content is user friendly, innovative, and meaningful (Hanover Research, 2018). Departments should regularly add new content about evolving programs and activities, the success of graduates, information on the return of investment for department graduates, and immediate connection to more information or enrollment possibilities. Departments should look to campus experts to ensure all content is in working order and to keep down the costs associated with web design. By relying on professionals and on-campus support, this will prevent lost time, which is often a concern of technology-related innovation (Block \& Estes, 2011). Support, which was one of the most popular categories of facilitation of entrepreneurship, lends itself well to these ventures. Relationships should be fostered both inside and outside of the department, and by finding experts or champions to support recruitment efforts, administrators should see positive results. 
A critical part of student recruitment is reassuring the consumer that they and their business are wanted. Expediting the admission decision shows the student the institution, and more importantly, the department wants them. This may stop the consumer from continuing to shop around and therefore increasing the chances of final enrollment. Another significant area of focus is related to current students and recent graduate referral programs. These programs could offer perks to all parties involved, related to tuition, fees, or even non-educational experiences (game tickets or memorabilia). This would depend on the flexibility of the institution, the rate of referrals, or the amount of revenue provided to sustain the initial efforts.

Kinesiology scholars should also continue to be innovative in their instructional sessions and techniques by increasing the use of summer and intersession blended learning. This should allow departments to profit as a result of the fragmentation of subdisciplines seen so often in higher education kinesiology (Block \& Estes, 2011). To benefit and advance the fields under the kinesiology umbrella, departments could expand the academic year to help learners progress quicker through their plans of study or complete additional and unique coursework specific to innovative new areas of study. Experiential learning opportunities were ranked as the worthiest of implementation of all the entrepreneurial initiatives on the survey. The expert panel deemed this area as very impactful and very feasible. This area would allow students to use experiences that occur outside of the traditional learning venues to develop knowledge, skills, and values necessary for their area of kinesiology.

To develop skills through experience, students could complete placements early on in their educational career to help them focus on specialties and learn from practitioners, enhancing engagement and the overall learning experience. While most physical education teacher education programs have placements throughout the program, this is lacking in other fields under 
the kinesiology umbrella, where students may not get in-field experiences until their senior capstone, internships, or after graduation. Programs may already have some of these placements in place in specific majors, making it feasible to replicate the process for other fields of study. The next step to benefit financially would be tying these opportunities to credits to allow the departments to profit from their efforts. Aligned with experiential learning, kinesiology departments should also focus on co-ops or internship placements. If a department was to take a more active role in this process and tie it back to coursework and credit completion, it could have a high impact. While the feasibility of this is lower than other categories, it is still worthy of implementation.

As higher education departments are pushed to become more businesslike, and corporations lean into continuing education for their employees, it is essential to examine the possibility for partnerships between the two (Herrmann, 2008). There were 12 entrepreneurial initiatives related to this concept, and it is worth discussing the three best areas of focus for potential areas of innovation. The item rated highest under this category was after-hours course scheduling. As many adults return to the educational field to further their careers, it may be beneficial to expand the times courses are offered past the traditional full-time student expectations. Panel members saw this as being financially impactful as it would increase the number of learners enrolled, but not as feasible faculty is needed to work those extra or later hours, which may put added pressure on an already stretched department (Milliken, 2004). Two other options for innovation would be online professional master's programs that can be completed through distance learning opportunities related to jobs already attained. These would be created through a partnership with employers and feature learning related to or occurring in real-world environments. The third area of focus would be designing or operating continuing 
professional development opportunities for corporations. This was rated as financially impactful but less feasible, in part because it is such a new concept that faculty may not fully understand their role in that process yet.

Testing and certification is one of the last areas of entrepreneurship that rated above average on both impact and feasibility. Although overall, the top three items in this category were rated lower than the previously mentioned, they were all considered as somewhat impactful, and one was even highly feasible. Coaching certification programs rated the highest out of all items in this area on the survey. With the continual increase in youth sport in America, it is necessary that coaches are properly trained (Authur-Banning, 2018), and this could be an excellent opportunity for programs to step up and use their knowledge to help their departments benefit financially. Two other areas were exercise testing and prescription, which already is occurring on some levels throughout the country (College of Education at The University of Texas at Austin, 2019). This would be an exceptional opportunity for exercise science departments to use their knowledge, skills, and equipment all the while educating their students, and benefitting financially. Both were rated similarly on impact and feasibility and could be a focus for programs with systems that may already be partially in place which would enhance the feasibility.

Two other items that were rated high in both impact and feasibility as related to the data were personal training and building testing and testing preparation into the curriculum. Personal training could be built in a variety of programs under the kinesiology department. It could be used in conjunction with the greater community population to help drive revenue into the department. This could be done on the part of the students through internships related to the course completion, graduate assistantships, or by the faculty. Rates of these training sessions 
could be related to the expertise of the personal trainer and the facilities in use. As higher education continues to be put through quality control matters dictated beyond the confines of the walls of the institution (Block \& Estes, 2011), students are often obligated to complete testing outside the institution. It may be beneficial for all parties involved (students, faculty, and department) to keep testing preparation and testing within the department, so students can pay the institution directly and use financial aid throughout the process rather than paying out of pocket to external providers.

While some groups of entrepreneurial initiatives did stand out more than others, it is essential to highlight individual items that were rated as both impactful and feasible to implement. Two additional items were accelerated degree programs and themed yearly lecture series. Accelerated degree programs were categorized as an applied and professional master's item. In kinesiology fields, such as teacher education, most graduates must continue their education through master's programs or standalone continuing education credits. Institutions could capitalize on this area of need by allowing students to overlap their degree work and complete advanced curriculum, earning multiple degrees in a shorter timeframe (i.e., three-year bachelor's degree). Departments can also use their expertise to host themed yearly lecture series that allows the faculty to bring their knowledge beyond the classroom and their general student population. Through promotion, in-house marketing, and charging for admission, departments can create a worthy revenue stream without much extra effort.

One of the essential parts of innovation is being realistic about the surrounding environment and not losing sight of what the purpose of higher education kinesiology is (Tierney, 2001). Kinesiology departments are just as diverse as the higher education landscape they represent, in size, scope, and focus. In order to implement any of the rated entrepreneurial 
initiatives, department faculty and administration need to assess any facilitators and barriers and how that may impact the feasibility of innovative techniques. The four primary areas of evaluation need to be related to support, belief, time, and money. Support factors were the most commonly listed theme in the second round of the survey. In order to enhance the ability to be entrepreneurial, the expert panel members encourage building "good relationships with the intellectual properties and continuing studies offices" (Response 1) on campus. They also encourage support to be built within the department on all levels, from staff to administration, in order to enhance the entrepreneurial spirit. The second most important area to facilitate entrepreneurial initiatives is the change in belief. Departments and, most importantly, universities should consider "incentives for implementation" (Response 9) of creative and innovative programming. Faculty should look for a champion of the initiative and sources of continual enthusiasm to increase the interest and ability to implement new opportunities.

While it is important to remain optimistic about efforts, there are also barriers to implementation that may harm the process or make things more challenging to get off the ground. The two most cited barriers were related to time and support. Panel members were concise in the language used related to time. However, more detailed responses listed the current faculty load and "lack of availability of personnel to deliver new programs" (Response 18). A lack of support was equally cited as a barrier to initiative implementation. This could come in the form of no support from the "contracts office," (Response 1), “administration” (Response 9), “staff” (Response 21), or “overall infrastructure” (Response 17).

Since support was one of the top factors that could positively or negatively impact implementation, it may be necessary for kinesiology faculty to begin to advocate and champion their cause early in the process. While support systems could be a barrier, more often they were 
advantageous. Relationships should be built with likeminded innovative individuals. These individuals are most likely to remain competitive and viable moving forward, while those who are inflexible and nonresponsive are less likely to survive in a hypercompetitive environment (Mourad, 1997).

\section{Practical Implications}

As the wider society continues to intervene with higher education and kinesiology, scholars must remain in control of the field. In order to do this, faculty and administrators must be willing to think innovatively and, at times, adopt sound business practices (Block \& Estes, 2011). This data can be used to help programs immediately and in the long run by providing a variety of ideas to drive in alternative revenue sources. While only a handful of entrepreneurial initiatives were discussed at length, the academy would benefit from examining each area of innovation and how it aligns with the brand and mission of their department. Scholars should be encouraged to make connections with programs currently excelling in innovation and entrepreneurship as well as build relationships on their campuses. Additionally, this study opens the discussion of the importance of scholars beginning to see themselves as entrepreneurs and active business partners in their institutions and departments. Scholars no longer can stand by as businesses encroach on their territory and aim to take over the knowledge business (Block \& Estes, 2011); instead, they must evaluate and evolve.

\section{Strengths and Limitations}

The current body of research related to entrepreneurship in higher education kinesiology lacks in a time where innovation is continually encouraged by the governing bodies (American Kinesiology Association, 2016a). This study begins to establish a foundation for others to follow by enabling experts in the field to come together to create, refine and rate items that can be 
implemented by departments in need. By selecting experts currently practicing and leading in the field of kinesiology, this study begins to bridge the gap between theory (hypothetical ideas related to possible entrepreneurship) and practice (actual possibility of ideas) based on their knowledge and skill set.

Although this research does have the strength of expert knowledge, it is also limited in several ways. The first is that there is small sample size when comparing to the overall field of kinesiology, and this only represents leaders who work in member departments of the American Kinesiology Association. Due to this criterion, some innovators in the field may have been excluded from the start of the selection process. There are also limitations based on the depth of knowledge provided as the data points in a Delphi study are never expanded on in great detail, instead just rated as they are supplied to the experts. Therefore some may have been interpreted differently depending on the short descriptions provided during each round. When examining the facilitators and barriers provided, there was not an exorbitant amount of detail given on the provided statements. This left interpretation through coding up to the researcher and independent rater. It is also imperative to keep in mind the differences from one department to another. The participants in this particular study represented a wide variety of kinesiology departments, including size, institution, student body, and fields of focus. As a result of these differences, all results and, therefore, recommendations should be thought of as highly individualized.

\section{Future Directions}

Due to the infancy of this line of research, many avenues could be next. First, it would be beneficial to examine how the field, specifically faculty and administrators, not involved in the study view these results. If departments do indeed plan to integrate some of the provided entrepreneurial initiatives, a case study on individual departments would be a significant step in 
enhancing the body of literature. Possible areas of questioning within the case study would be some of the following. What the department chooses to implement and their decision making behind this process. How long did this implementation take, and who were the key stakeholders involved? How long did it take for the program implemented to become profitable? Were the previous Delphi ratings (impact and feasibility) an accurate reflection? How did the facilitators and barriers identified in this study impact programmatic implementation? Lastly, who is taking the lead, and how can these programs be transferred over to more institutions to help maintain and strengthen the field as a whole? Additionally, these questions could be posed in a focus group format to get a variety of in-depth perspectives and conversations on this emerging research line.

After additional research through case studies of successful and unsuccessful entrepreneurial initiatives, there may be enough research to begin to develop a framework that can be used to guide struggling departments. This would allow the risk and reward to be more predictable in an already thinly stretched and financially troubling environment.

\section{Conclusion}

Higher education is continually evolving, and as it changes, so do the demands of faculty and administration. While the field of kinesiology has not completely neglected the conversation related to entrepreneurship, the research is currently lacking. Through the Delphi method, administrators in kinesiology were able to rate and identify three areas to focus on in terms of innovation and entrepreneurship. These areas, community partnerships, student recruitment, and summer and intersession blended learning are not necessarily new concepts, but the data related to their impact and feasibility is not highly researched. This study starts to bridge conversation and research and, as a result, hopefully, a way out of tough financial times for many departments 
and institutions. By identifying multiple ways these areas can be implemented in departments, it is the goal that higher education kinesiology departments can identify sound techniques to create alternative revenue streams in a period marked by a continual decrease of public financial support and the encouragement of freezing or even decreasing tuition. 


\section{References}

Adler, M., \& Ziglio, E. (1996). Gazing into the oracle: The Delphi method and its application to social policy and public health. London: Jessica Kingsley Publishers.

Agosti, C. I., \& Bernat, E. (2018). University pathway programs : Types , origins , aims and defining traits. In C. I. Agosti \& E. Bernat (Eds.), University pathway programs: Local responses within a growing global trend (pp. 3-25). Springer International Publishing AG.

American Kinesiology Association. (2016a). Entrepreneurial opportunities. In AKA Leadership Workshop. Phoenix, AZ.

American Kinesiology Association. (2016b). Increasing external funding. In AKA Leadership Workshop. Phoenix, AZ.

American Kinesiology Association. (2019). About AKA: Definition of kinesiology. Retrieved from http://www.americankinesiology.org/SubPages/Pages/About

Astin, A. W. (1998). The changing American student: Thirty-year trends, 1966-1996. The Review of Higher Education, 21(2), 115-135.

Astin, A. W., \& Antonio, A. L. (2012). Assessment for excellence: The philosophy and practice of assessment and evaluation in higher education. Lanham: Rowman \& Littlefield Publishers Inc.

Authur-Banning, S. (2018). Youth sports in America: the most important issues in youth sports today. (P. B. Greenwood \& M. S. Wells, Eds.). Santa Barbara, CA: ABC-CLIO, LLC.

Barnett, R. (2000). Supercomplexity and the Curriculum. Studies in Higher Education, 25(3), 255-265. https://doi.org/10.1080/713696156

Barnett, R. (2004). The Purposes of Higher Education and the Changing Face of Academia. London Review of Education, 2(1), 61-73. https://doi.org/10.1080/1474846042000177483 
Batten, D. D. (2011). The G.I. Bill, higher education and American society. Grove City College Journal of Law \& Public Policy, 2(1), 13-30.

Baum, S., \& Ma, J. (2011). Trends in college pricing 2011. New York, New York. Retrieved from http://trends.collegeboard.org/sites/default/files/trends-college-pricing-web-final-5082.pdf

Baum, S., \& Payea, K. (2014). Trends in student aid 2012. New York. Retrieved from http://trends.collegeboard.org/sites/default/files/student-aid-2013-fullreport.pdf\%5Cnpapers2://publication/uuid/74B810D6-8F4C-4D9E-860C-E5FE702152FD

Baum, Sandy, Kurose, C., \& McPherson, M. (2013). An overview of American higher education. The Future of Children, 23(1), 17-39. https://doi.org/10.1353/foc.2013.0008

Biesheuvel, W., Jansen, R., Johnson, N., \& Neghina, C. (2015). New routes to higher education: the global rise of foundation programmes. Retrieved from http://www.studyportals.com/intelligence/foundation-programmes/

Block, B. A., \& Estes, S. (2011). Supercomplexity in higher education kinesiology. Quest, 63(2), 179-196. https://doi.org/10.1080/00336297.2011.10483675

Bloland, H. G. (2005). Whatever happened to postmodernism in higher education? No requiem in the new Millennium. Journal of Higher Education, 76(2), 121-150.

Boehm, J. (2008). Entrepreneurial Orientation in Academia (1st Editio). Germany: Springer Science+Business Media.

Bowen, W. G. (2012). The 'cost disease'in higher education: is technology the answer? The Tanner Lectures Stanford University, (October). Retrieved from http://new.oberlin.edu/dotAsset/a0e24144-e4f3-48fc-b856c407ff37b50e.pdf\%5Cnpapers3://publication/uuid/7C85F2C6-3160-4D73-8828- 


\section{EF35ECDD796B}

Boyer, E. L. (1990). Scholarship reconsidered: Priorities of the professoriate. Lawrenceville, New Jersey: Princeton University Press.

Brint, S., Turk-bicakci, L., \& Levy, C. S. (2016). From the Liberal to the Practical Arts in American Colleges and Universities : Organizational Analysis and Curricular Change Author ( s ): Steven Brint, Mark Riddle, Lori Turk-Bicakci and Charles S . Levy Published by : Ohio State University Press Stabl, 76(2), 151-180.

Brooks, K. W. (1979). Delphi technique: Expanding applications. No Central Assoc Quarterly, $53,377-385$

Brown, R. (2008). What will successful organizations look like? In K. Herrmann, R. Brown, \& S. Scott-Davies (Eds.), Leadership in an age of supercomplexity: Challenges for 21st century universities and businesses (pp. 11-13). London: Council for Industry and Higher Education.

Bulger, S. M., \& Housner, L. D. (2007). Modified Delphi Investigation of Exercise Science in Physical Education Teacher Education. Journal of Teaching in Physical Education, 26, 5780.

Burt, J. (1987). Three dreams: The future of HPERD at the cutting edge. In J. D. Massengale (Ed.), Trends toward the future in physical education (pp. 153-168). Champaign, IL: Human Kinetics Publishers, Inc.

Castells, M. (1996). The information age: Economy, society, and culture. Oxford: Blackwell Publishers.

Chapman, D. W., \& Austin, A. E. (2002). Higher education in the developing world: Changing contexts and institutional responses. (P. G. Altbach, Ed.). Westport: Greenwood Press. 
Cheslock, J. J., \& Knight, D. B. (2015). Diverging Revenues, Cascading Expenditures, and Ensuing Subsidies: The Unbalanced and Growing Financial Strain of Intercollegiate Athletics on Universities and Their Students. The Journal of Higher Education, 86(3), 417447. https://doi.org/10.1353/jhe.2015.0017

Christensen, C. M., \& Eyring, H. J. (2011). The innovative university: Changing the DNA of higher education from the inside ou. John Wiley \& Sons. https://doi.org/10.5465/amle.2013.0301

Clark, D. A. (1998). The two Joes meet- Joe college, Joe veteran: The GI Bill, college education, and postwar American culture. History of Education Quarterly, 38(2), 165-190.

Clayton, M. J. (1997). Delphi: a technique to harness expert opinion for critical decision-making tasks in education. Educational Psychology, 17(4), 373-386. https://doi.org/10.1080/0144341970170401

College of Education at The University of Texas at Austin. (2019). Fitness Institute of Texas: History of FIT. Retrieved from http://sites.edb.utexas.edu/fit/history-of-fit/

Corbin, C. B. (1993). Clues from dinosaurs, mules, and the bull snake: Our field in the 21st century. Quest, 45(4), 546-556. https://doi.org/10.1080/00336297.1993.10484105

Cubie, A. (2008). The 'business' dimensions of higher education. In K. Herrmann, R. Brown, \& S. Scott-Davies (Eds.), Leadership in an age of supercomplexity: Challenges for 21st century universities and businesses (pp. 14-16). London: Council for Industry and Higher Education.

Delbecq, A. L., \& Van de Ven A, G. D. (1975). Group Techniques for Program Planning: A Guide to Nominal Group and Delphi Processes. Glenview, IL: Scott, Foresman, and Company. 
Deming, D., Goldin, C., Katz, L., Deming, D., Goldin, C., \& Katz, L. (2018). For-Profit Colleges, 23(1), 137-163.

DePauw, K. P. (1998). Futurisktic perspectives for kinesiology and physical education. Quest, $50,1-8$.

Educational Advisory Board. (2013). Alternative revenues in higher education, 1.

Ellis, M. (1987). The business of physical education. In J. D. Massengale (Ed.), Trends toward the future in physical education (pp. 69-84). Champaign, IL: Human Kinetics Publishers, Inc.

Elwood, T. W. (2013). The changing landscape of higher education. Journal of Allied Health, $42(2), 63$.

Frederiksen, C. F. (1993). A brief history of collegiate housing. In R. B. Winston, S. Anchors, \& Associates (Eds.), Student housing and residential life (pp. 167-183). San Francisco, CA: Jossey-Bass.

Giddens, A. (n.d.). The Great Globalization Debate, Zellerbach Distinguised Lecture, University of California, Berkeley.

Goldin, C., \& Katz, L. F. (1999). The shaping of higher education: The formative years in the United States, 1890 to 1940. Journal of Economic Perspectives, 13(1), 37-62. https://doi.org/10.1257/jep.13.1.37

Hanover Research. (2017). Hanover Research 2017 industry trend report. Arlington, VA. Hanover Research. (2018). Trends in higher education 2018. Arlington, VA.

Hardin, C. J. (2008). Adult Students in Higher Education: A Portrait of Transitions. New Directions for Higher Education, (144), 49-27. https://doi.org/10.1002/he

Hellison, D. (1987). Dreaming the possible dream: The rise and triumph of Physical Education. 
In Trends towards the future of Physical Education (pp. 137-151). Champaign: Human Kinetics.

Hendrickson, R. M., Lane, J. E., Harris, J. T., \& Dorman, R. H. (2013). Academic leadership and governance of higher education: A guide for trustees, leaders and aspiring leaders of twoand four-year institutions. Sterling, Virginia: Stylus Publishing.

Henry, F. M. (1964). Physical education: An academic discipline. Journal of Health, Physical Education, and Recreation, 35(7), 32-33.

Herrmann, K. (2008). Leadership in an age of supercomplexity. In K. Herrmann, R. Brown, \& S. Scott-Davies (Eds.), Leadership in an age of supercomplexity: Challenges for 21st century universities and businesses (pp. 7-10). London: Council for Industry and Higher Education. Ho, A. D., Chuang, I., Reich, J., Coleman, C. A., Whitehill, J., Northcutt, C. G., ... Petersen, R. (2015). HarvardX and MITx : Two Years of Open Online Courses Fall 2012-Summer 2014. SSRN Electronic Journal, (10), 1-37. https://doi.org/10.2139/ssrn.2586847

Hofstadter, R., \& Hardy, C. D. (1952). The development and scope of higher education in the United States. New York, New York: Columbia University Press.

Jacobs, J. M. (1996). Essential assessment criteria for physical education teacher education programs: A Delphi study (doctoral disseration, West Virginia University). Dissertation Abstracts International, 57, 2938.

Kazdin, A. E. (2011). Single-case research designs (2nd ed.). Ozford University Press.

Krahenbuhl, G. S. (1998). Higher Education in the 21st Century : The Role of Kinesiology and Physical Education. World Health, 6297(February), 108-115. https://doi.org/10.1080/00336297.1998.10484267

Lanford, H. W. (1972). Technological forecasting methodologies: A synthesis. New York, New 
York: American Management Association, Inc.

Lee, G. C. (1963). The Morrill act and education. British Journal of Educational Studies, 12(1), 19-40. https://doi.org/10.1080/00071005.1963.9973102

Lierman, W. (1996). Euro Delphi: A comparative study on the future of adult education in 14 countries between 1993 and 1995. Journal of Lifelong Education, 15, 125-138.

Massengale, J. D. (2000). Doing PE at the new university. Quest, 52, 102-109. https://doi.org/10.1007/s11423-011-9194-5

McNeil, A. (1987). Wellness programs and their influence on professional preparation. In J. D. Massengale (Ed.), Trends toward the future in physical education (pp. 85-94). Champaign, IL: Human Kinetics Publishers, Inc.

Meyer, A. E. (1975). Grandmasters of educational thought. New York, New York: McGraw Hill.

Miller, M. T., \& Husmann, D. E. (1994). Strategies for improving instructional delivery in distance education programs. Journal of Adult Education, 22, 23-29.

Milliken, J. (2004). Thematic reflections on higher education. Higher Education in Europe, 29(1), 9-18. https://doi.org/10.1080/03797720410001673265

Mourad, R. (1997). Postmodern philosophical critique and the pursuit of knowledge in higher education. Westport, CT: Bergin \& Garvey.

Murry, J. W., \& Hammons, J. O. (1995). Delphi: A Versatile Methodology for Conducting Qualitative Research. The Review of Higher Education, 18(4), 423-436. https://doi.org/10.1353/rhe.1995.0008

Newell, K. (1990). Physical education in higher education: Chaos out of order. Quest, 42(227242). 
Parentè, F. J., \& Anderson-Parentè, J. (1987). Delphi inquiry systems. In G. Wright \& P. Ayton (Eds.), Judgmental Forecasting (pp. 129-156). New York, NY: John Wiley \& Sons.

Ramsey, C., Hawkins, A., Housner, L. D., Wiegand, R. L., \& Bulger, S. M. (2009). Finding the recipe for the best blend: The evolution and assessment of a blended Master's degree program. Journal of the Research Center for Educational Technology, 5(2), 3-26.

Sage, G. (1987). The future and the profession of physical education. In J. D. Massengale (Ed.), Trends towards the future of Physical Education (pp. 9-23). Champaign, IL: Human Kinetics, Inc.

Sandrey, M. a, \& Bulger, S. M. (2008). The Delphi Method: An Approach for Facilitating Evidence Based Practice in Athletic Training, 3(4), 135-142.

Serow, R. C. (2004). Policy as symbol: Title II of the 1944 G.I. Bill. The Review of Higher Education, 27(4), 481-499.

Slaughter, S. (1998). Federal policy and supply-side institutional resource allocation at public research universities. The Review of Higher Education, 21(3), 209-244.

Smith, C. L. (1992). National issues and concerns in marketing teacher education. Marketing Educators' Journal, 30, 75-89.

Snyder, T. D., de Brey, C., \& Dillow, S. A. (2016). Digest of education statistics 2015. Washington, DC. https://doi.org/10.5860/CHOICE.51-5366

Snyder, T. D., \& Dillow, S. A. (2012). Digest of education statistics 2011. Digest of education statistics 2011. https://doi.org/NCES 2012-001

Snyder, Thomas D. (1993). 120 years of American education: A statistical portrait. Statistics. Retrieved from http://nces.ed.gov/pubs93/93442.pdf

Snyder, Thomas D. (2016). Digest of educational statistics 2016. Washington, DC. Retrieved 
from https://nces.ed.gov/programs/digest/d16/index.asp

Snyder, Thomas D, \& Hoffman, C. M. (2002). Digest of education statistics 2001. Washington, DC. https://doi.org/10.1037/e492182006-003

Southern Regional Education Board. (1974). The academic common market, 22.

Strohl, N. M. (2006). The postmodern university revisited: reframing higher education debates from the 'two cultures' to postmodernity. London Review of Education, 4(2), 133-148. https://doi.org/10.1080/14748460600855195

Tesch, R. (1990). Qualitative research: Analysis types and software tools. New York: Falmer Press.

Tewksbury, D. (1965). The founding of American colleges and universities before the Civil War: with particular reference to the religious influences bearing upon the college movement. New York, New York: Archon Books. Retrieved from http://www.tcrecord.org/Content.asp?ContentID=12572

The National Association for College Admission Counseling. (2018). 2017 state of college admission. The Journal of College Admission, (238), 24.

Tierney, W. G. (2001). The autonomy of knowledge and the decline of the subject: Postmodernism and the reformulation of the university. Higher Education, 41(4), 353-372.

Toby, J. (2010). How scholarships morphed into financial aid. Academic Questions, 23(3), 298310.

Trow, M. A. (2006). Reflections on the transition from elite to mass to universal access: Forms and phases of higher education in modern societies since WWII. In J. Forest, James \& G. Altbach, Philip (Eds.), International Handbook of Higher Education (pp. 243-280). Dordrecht: Springer. 
U.S. Department of Commerce, B. of the C. (1975). Historical statistics of the United States from colonial times to 1970. Washington, DC.

UPCEA Hallmarks of success in professional and continuing education. (2018). Washington, DC.

Vagias, W. M. (2006). Likert-type scale response anchors. Clemson International Institute for Tourism and Research Development, Department of Parks, Recreation and Tourism Managment., 3-4. https://doi.org/10.1525/auk.2008.125.1.225

Veysey, L. (1965). The emergence of the American research university. Chicago, Illinois: University of Chicago Press.

Welch, A. R. (2001). Globalisation, post-modernity and the state: Comparative education facing the third millennium. Comparative Education, 37(4), 475-492.

Wills, J. E. (2018). The post-postmodern university. Change, 27(2), 59-62.

Wilmore, J. H. (1998). Building strong academic programs for our future. Quest, (50), 103-107.

Zusman, A. (2011). Challenges facing higher education in the twenty-first century. In P. G. Altbach, P. J. Gumport, \& R. O. Berdahl (Eds.), American Higher Education in the TwentyFirst Century: Social, Political, and Economic Challenges (pp. 115-160). Baltimore, Maryland: JHU Press. 


\section{Appendix A: Extended Literature Review}

\section{Extended Literature Review}

Higher education has gone through radical and continual changes since its inception. The absolute number, type, structure, and purpose have transitioned from little to no variation, to a system hard to classify as it exists today. As a result of the many changes, student populations for American higher education are as diverse as ever and push institutions to address their different expectations (Hendrickson et al., 2013). Higher education institutions have entered a time best described and viewed through the lens of supercomplexity. One where existing traditional frameworks no longer suit the issues prevalent in a global, digital, inclusive, and highly competitive world (Barnett, 2000).

Higher education now finds itself fighting for resources, populations, and space in a more business-oriented world and as a result is entering frontiers only once brushed upon (Zusman, 2011). As one way to stay afloat higher education institutions are becoming more entrepreneurial and looking to take financial risks beyond traditional avenues (Boehm, 2008). Universities and colleges seek to identify new educational revenues and the infrastructure needed to continue to thrive in an ultra-competitive market (Educational Advisory Board, 2013).

While kinesiology as a higher education field has not been in existence for the entirety of American higher education, it has followed and coped with the same transitions. Once a field, with little variety, kinesiology now encompasses a wide array of disciplines (Newell, 1990). The field competes for funding, enrollment, and catering to the needs and pressures of wider society (Block \& Estes, 2011). As a result of the demands, many higher education programs in kinesiology have turned to entrepreneurial initiatives as well, to stand out, succeed, and even flourish (American Kinesiology Association, 2016a). 


\section{History of American Higher Education}

The story of higher education in America is older than the country itself. One that began with little diversity has changed to a varied structure that was almost unpredictable (Hendrickson et al., 2013). American higher education has adapted to meet the needs of its citizens as the young country found itself becoming first a player and then a leader on a global level. Just as many industries in the country, it grew slowly at first and focused on the needs of the elite classes (Lee, 1963). It then evolved and began to take on many of its modern features at the same times as the industrial revolution changed the footprint of the country (Hofstadter \& Hardy, 1952; Veysey, 1965). At the turn of the $20^{\text {th }}$ century, it continued to meet society's needs, embracing returning troops after World War II, diversifying in the 1960s and 1970s, and moving into new virtual worlds of learning in the $21^{\text {st }}$ century (Snyder, 1993). While the entirety of history related to higher education in America would be exhaustive, this will aim to provide insight to some key areas of change including the landscape, purpose, and revenue of colleges and universities. Over the centuries since its inception, the one constant of American higher education seems to be its ability to adapt to fit a growing and diversified country (Hendrickson et al., 2013).

American higher education landscape. The higher education landscape of America is as varied as the country it represents. The system has grown from one institution to over four thousand in its less than four-hundred-year history. Its earliest years consisted of primarily private religious institutions, but now there is an array of public, private, and for-profit colleges and universities (Hendrickson et al., 2013). In the most recent decades, there has been considerable change in the structure, breaking down the walls and moving into virtual classrooms to reach the world (Bowen, 2012). There has also been unpredictable change related 
to the diversity of the learners. It may not be possible to describe every nuance of the system, but it is essential to recognize critical elements that have evolved. To provide insight into these elements, the history of American higher education will be divided into four phases that carry significant differences regarding the number, type and structures of institutions, as well as the panelists.

Elite education. Higher education in America began as early as the colonial period, with the inception of what later became Harvard University in 1636. Initially, educational institutions were established and centered around religious denominations and assisting in the general diffusion of knowledge (Meyer, 1975; Tewksbury, 1965). The earliest higher education campuses were very small, on average, the enrollment was approximately 112 students and often consisted of one academic building (Snyder, 1993). Some early institutions did offer to house full-time students, but the intention was to assist with the physical and even mental isolation of the learners, which aligned with the purpose of post-secondary education at the time (Frederiksen, 1993). Higher education, similar to all levels of education in colonial America was comprised primarily of high class, white citizens.

Expanding education. Although growth in absolute numbers of institutions was slow at first, it accelerated throughout the latter part of the 19th century (Thomas D. Snyder, 1993). At the time of the initial data cycle in 1869-70, there were already 563 established higher education institutions in America. Growth continued over the majority of the decade until it finally peaked 20 years later in 1889-90, with 998 colleges and universities. The next twenty years, surrounding the turn of the 20th century, saw the first decline in higher education with a decrease of 52 institutions. Although, this decrease may in part be a result of the consolidation of professional 
schools into larger public institutions. The higher education market did rebound quickly after that with a surge of 90 newly founded institutions from 1910-1920, bringing the total to 1,041.

The early 1800s saw the creation and expansion of normal schools, which were two-year institutions designed to prepare public school teachers. As public school at the elementary and secondary levels increased, so did the need for public higher education. This need led to the first public colleges gaining a charter, the University of Georgia and the University of North Carolina, which was the first to open. Shortly after that, public colleges continued to expand, with 21 state colleges being established by 1860 (Tewksbury, 1965).

As colleges became accessible and student enrollment and interests diversified, so did the look of the campus structure. Buildings and learning spaces became discipline-specific, and there were also more amenities (Goldin \& Katz, 1999).

By 1869-70, it is estimated that only about one percent of the 18 - to 24 -year-old population was attending a post-secondary institution. While men did dominate the higher education landscape for the first few centuries, at the time of initial data collection, women did represent $21 \%$ of college participants (Snyder, 1993). The proportion of the 18- to 24-year-old population attending higher education institutions continued to increase throughout the early decades of the $20^{\text {th }}$ century, with women seeing a sharp growth of enrollment. This trend continued until the Great Depression when growth slowed, and there was a decrease in the proportion of women from a high of $47 \%$ to just $40 \%$ (Snyder, 1993). At this time, there was also an increase in blacks attending post-secondary institutions, as many of the state schools established around the turn of the $20^{\text {th }}$ century were for women or blacks (Goldin \& Katz, 1999). By the conclusion of the 1930s, the portion of the American population that had completed at 
least four years of post-secondary education had nearly doubled, from $2.7 \%$ in 1910 to $4.6 \%$ in 1940 (Snyder \& Hoffman, 2002).

Attainable education. The growth of American higher education continued after World War II, reaching a total of 3,587 institutions at the time of the 1987-88 data collection cycle. In the late 1980s, there is a slight decrease in higher education institutions reported, but this may be in part a result of institutions that submitted one set of data for main and branch campuses (Snyder, 1993).

The landscape of American higher education remained steady throughout the 1940s and 1950s, merely increasing capacity at the already existing institutions. It was not until the 1960s and 1970s that there was another significant shift in the type of institutions when the growth and development of community colleges increased the range of choice in higher education (Elwood, 2013). This increase of the community colleges continued at a rapid and uneven rate through the 1970s and 1980s (Trow, 2006). As a result of this increase, undergraduate education was provided primarily through public two and four-year institutions and private nonprofit colleges. The private for-profit institutions were too small to track during these decades (Baum et al., 2013).

The most significant change in student body was after WWII as men returned from overseas and began enrolling in institutions at record rates (Snyder, 1993). At one point during the post-war period, veterans accounted for approximately $49 \%$ of students enrolled in higher education institutions (Mettler, 2005). Due to this influx of students, by the end of the 1940s, about $15 \%$ of the 18 - to 24 -year-old population was enrolled in post-secondary education, but the proportion of women had dropped to $30 \%$ (Snyder, 1993). Veterans changed the face of higher education for many reasons, including that they were older than traditional students (Brint et al., 
2016). Also, there was a shift in perception about who could attend college. Seemingly regular Americans were able to break down the boundaries of the ivory towers and challenge traditional racial and ethnic divides of higher education (Clark, 1998).

The 1950s and 60s saw a continuation of large numbers of young people enrolling in higher education institutions. Both accounting for a total increase of $20 \%$ of the population attending higher education institutions, $41 \%$ of which were women (Snyder, 1993). The 1970s saw a slower period of growth in enrollment, but there were significant increases in part-time students. This increase of $10 \%$ was in part due to the increased rate of older students, with just over a quarter (28\%) being older than 24 and the expansion of the two-year college systems that saw a doubling in enrollment (Snyder \& Dillow, 2012). In 1979, another significant change was evident, when women became most of the population on college campuses in America (Snyder, 1993).

Mass education. There has been a continual rise in the number of higher education institutions in American until the last collection, 2015-16, which reported 4,583 Title IV degreegranting colleges and universities and an additional 2,247 Title IV non-degree-granting institutions (Snyder, de Brey, \& Dillow, 2016).

The impact of the changes made to higher education decades ago, such as accessibility and affordability of community colleges, as well as the increase in private for-profit institutions, has left a lasting impact on higher education. Today there are more undergraduate students enrolled in community colleges than in public four-year universities (Snyder \& Dillow, 2012). One more significant change is that of the students who attend private institutions, close to a third or six percent of all FTE enrollment, attend for-profit places (Baum \& Payea, 2014; Snyder \& Dillow, 2012). Despite this growth in enrollment in for-profit colleges, public institutions 
continue to be the largest in enrollment (Goldin \& Katz, 1999), although this continues to be threatened as institutions become more "privatized" to offset declining public funding (Zusman, 2011).

For-profit colleges and universities are one of the fasting growing groups of higher education institutions. Currently, they are also one of the most varied, with some of the largest enrollments as well as the smallest (Deming, Goldin, \& Katz, 2018). While these institutions have been around for more than a century, it was not until recent decades that there was a significant shift in focus. In the past, for-profit or proprietary institutions focused on courses or certifications, but more recently they have expanded into bachelors and graduate degrees. As a result, they have more than tripled their collective enrollment since 2000 with $90 \%$ attributable to large national chains. It is these chains that have become highly profitable and publicly traded corporations as a result (Deming et al., 2018).

Over the past several decades, students have become demanding consumers, expecting a life like what they have known for their first 18 years of life. Higher education campuses have expanded immensely and offer much more than the classrooms, dormitories, and libraries of the past. Twenty-first-century universities have found themselves in an arms-race, investing millions into recreation centers, athletic facilities, and state of the art student living quarters (Cheslock \& Knight, 2015).

Colleges have also expanded throughout their respective states, leading to an expansion of branch campuses to keep up with expectations. While branch campuses appear similar to community colleges, they differ in that they often offer the same amenities of large institutions, but close to home (Hendrickson et al., 2013). These institutions have also entered the newest frontier, of online education in addition to local and global satellite campuses. As internet access 
has become more popular so has the use of online learning and classrooms (Bowen, 2012).

Students can now not only complete courses online but also entire degrees. As of 2015, some of the largest American institutions are offered mostly online, with the University of Phoenix, Arizona ranking first for enrollment with over 165,000 students. In fact, out of the top ten universities, seven institutions have more online presence and enrollment than on campus (Snyder, 2016).

In addition to growing numbers related to online education, there has also been an increase in participation of Massive Open Online Courses (MOOCs; Ho et al., 2015). Highly regarded professionals in academic fields typically design these courses which run primarily through computer generated programs, with little actual professional interaction. They are offered through a variety of formats, but most include videos and assignment completion, which are graded primarily through computers, peers, or teacher assistants (Ho et al., 2015). One primary difference between MOOCs and traditional online-education is MOOCs often do not result in credits or degrees. Instead, they focus on the process of learning or possible certificate completion. Two of the three largest platforms currently in use, Coursera and Udacity are both for-profit spin-offs created by Stanford. The third edX is a non-profit partnership of MIT, Harvard, and Berkley (Bowen, 2012). While MOOCs are often overlooked components of higher education participation research since they do not lead to degree completion, they are viable and popular options for continued education. Edx alone had over 1 million unique participants in a two year period from their opening in 2012 until 2014 (Ho et al., 2015).

Enrollment in degree-granting institutions continued to increase throughout recent decades as well (Snyder et al., 2016). This continued growth in enrollment is attributable to diversity in race, age, and ability levels. In the almost 40-year period from 1976 to 2014, the 
percentage of minorities, saw increased enrollment percentages, both regarding the percentage of all college students and within their population (Snyder et al., 2016). When looking specifically at a period from 2004-2014, the enrollment rate for Hispanic American students rose ten percent to a total of $35 \%$. It was also during this same period that there was a decrease in the percentage of White American students who comprised the higher education student body from $84 \%$ to $58 \%$ (Snyder et al., 2016).

Another significant increase relates to the influx of students age 25 or older. While they are still the minority on campuses, the rate of enrollment increased by $16 \%$ during a ten-year period from 2004-2014. Also, NCES predicts that the rate of enrollment for students aged 25 and older will outpace that of students under 25 years of age over the next ten-year period (Snyder et al., 2016). Lastly, there has also been an increase in students with disabilities on American higher education campuses. During the 2011-12 academic year, 11\% of students reported having a disability (Snyder et al., 2016).

Purpose of higher education. Higher education in American has seen a transition in the purpose that it serves to its attendees and the general public. In their earliest days, institutions focused primarily on religion and later expanding one's mind through the arts and sciences. Then came a shift towards the needs of an evolving society, with a primary focus on the practical arts necessary to train a larger population of full-time students. Lastly, there was a shift to what is higher education in America is currently, an almost fluid education that can be attended at any time, from anywhere, for almost any purpose. While the goals and purpose of higher education have become very broad, one constant is the ability for higher education to transform to meet the needs of a greater society. 
During its earliest years, the American higher education system was very limited in size and scope. Most institutions were theological and religious colleges that focused on religion over intellect, but this began to shift in the 18th century. During this time, the study of modern languages, mathematics, and sciences began to take over the majority of colleges. These fields continued to represent the higher education landscape throughout the century, with institutions focusing on religion, liberal studies, and professions such as law and medicine (Lee, 1963).

Throughout the early decades of the 1900s, higher education continued on the path established in the prior century. While diversity was increasing relative to the purpose of attending a higher education institution, the majority of studies still focused on liberal arts education (Brint et al., 2016). Education was still mostly limited to the elite classes and was intended for the pursuit of knowledge "for its own sake." It was not until a few years before the Great Depression, that this dominance began to slip, with an increase in focus on practical arts.

This increase continued throughout the 1930s, even lasting past the return of the troops from World War II. This group of students was changing the face of American higher education, and rather than pursuing an advanced degree for mere knowledge; most were in pursuit of gaining better employment and professional careers as a result of higher education. Since the 1930s, the only time the practical arts have not had the majority of college graduates, was in the 1960s when there was a brief period of control by the arts and sciences (Brint et al., 2016).

Since the 1970s, the fastest-growing fields have been in practical arts, with as many as two out of every three degrees awarded in these fields during the mid-1980s (Brint et al., 2016). According to Slaughter (1998), one reason for this shift may be an increase in federal financial aid, has led to lower-income students who see particular degrees linked to jobs attainment and loan repayment. The concept that higher education leads to graduates becoming financially better 
off is evident in the literature. According to one survey, the proportion of college freshman attending colleges to develop "a meaningful philosophy of life" has decreased $45 \%$ over the same period that the proportion attending to "become well-off financially" has increased by more than $40 \%$ (Astin, 1998).

In addition to career attainment and advancement, the current shift that is occurring in American society and higher education is the need for continuing education. In a quickly evolving world, it is more important than ever before that professionals in fields related to education and sciences continue to stay relevant to advancing knowledge. While the educational experience used to be time-bound, with clear discontinuation after four or six years, continuing education can now span careers for decades. Professional and continuing education programs are becoming the norm at most institutions to cater to the rapid invention of new categories of work, the growing population of adult learners, and the value placed on current knowledge (UPCEA, 2018).

Funding of higher education. Since the inception of higher education, there have always been multiple forms of funding in place. As the system grew and diversified, it came to rely on financial support from governments, families, and philanthropy, although the brunt of the load has shifted substantially from century to century (Hendrickson et al., 2013). That shift started with the participant and philanthropy paying many of the expenses, but this began to shift substantially in the 1800 s. It was at this time that federal and later state governments stepped in and continued to increase their support well into the mid-1900s (Lee, 1963). As higher education continued to grow this support was unsustainable, and individual tuition started to increase, accompanied by individual grants and loans (Baum et al., 2013). Most recently, there has been a 
shift in looking for alternative revenue streams to compensate for ever-decreasing funds (Zusman, 2011).

Public dollars. In its earliest days, funding for education relied entirely on private and local sources of financial support. These sources were often derived from religious sects based on the long-standing affiliation of education and religion (Lee, 1963). Funding for education in American began to change in the late 1700s when the first donation of public lands for the benefit of public education occurred in Ohio. As territories were granted statehood, it was deemed that sections of land would be set aside for public schools and universities with endowments being established along the way. It was not until the mid-1800s, that many already established states petitioned for similar federal aid related to higher education, beginning with Illinois in 1853. It was these actions that led up to the passing of the Morrill Act of 1862 (Lee, 1963).

The Morrill Act was instrumental in changing many aspects of American higher education, most notably funding institutions. This act was broken down into three key parts; the first was the allotment of federal lands for sale (either within the state or otherwise granted to the state). The total allotment was equal to 30,000 acres for each state representative and senator. The second part of the Act was the designation of for what the funds could be used. It was deemed that profits must be used to establish at least one higher education institution within the state, with a primary focus related to agriculture and mechanic arts. The third part was the establishment and maintenance of an endowment fund for the state/institution. This act not only encouraged states to support higher education but in many ways, it forced them, especially expansion into practical arts and fields. By 1885, 69 institutions benefitted from the Morrill Act 
of 1862, including 20 separate Agriculture and Mechanics institutions and 17 HBCUs (Lee, 1963).

The second Morrill Act continued to influence funding in higher education, with the mandate that states must provide a separate but equal higher education institution for students of color. Before this act, only three states, Virginia, South Carolina, and Mississippi used any landgrant funds of black collegiate education. The second act stimulated significant steps for all 17 states to publicly fund and support black higher education institutions (Lee, 1963). It is difficult to assess the effect of either Morrill Act at the time of implementation, based on the fact that there was little systematic thought about specifics (Lee, 1963).

Public support from states continued throughout the turn of the 20th century, with state spending on public higher education institutions doubling from 5.1 percent to 11.0 percent from 1902-1940 (U.S. Department of Commerce, 1975). In 1929, states on average were spending six percent of their total expenses on higher education, with $95 \%$ of those funds going to publiclycontrolled higher education institutions (Goldin \& Katz, 1999). Public support for higher education continued to differ from state to state and more importantly from region to region. The late state entrants were not only leaders of the high school movement, but they also had high levels of college enrollment. This was in part due to the difference in support and funding of public higher education. The states with high private university enrollments as of 1900, typically provided less support per capita for public institutions than their counterparts out west, this trend continues until the present day (Goldin \& Katz, 1999).

With the return of WWII veterans, came another change in federal financial support, the Servicemen's Readjustment Act of 1944, also known as the G.I. Bill. The G.I. Bill was unique in that it offered funds up to $\$ 500$ for tuition with an additional stipend for living expenses with all 
veteran students. These funds were allocated directly to the veteran student rather than to the institution (Serow, 2004). Before this program, scholarships were limited, often based on merit, and financed without federal involvement. The G.I. Bill was the precursor of the transition from primarily merit-based assistance to the needs-based assistance that is present today. This also set a precedent for future federal funds being awarded to both secular and religious institutions and federal involvement in higher education as a whole (Batten, 2011; Toby, 2010).

As higher education institutions continued to expand, so did student expectations, leading to a continued increase in state and federal spending. Two federal programs were introduced in the 1960s and 1970s to meet these new expectations. The first was the Higher Education Act under Johnson in 1965 and the second the Basic Educational Opportunity Grant program (later renamed the Pell Grants) under Nixon in 1972 (Baum et al., 2013). Following these two programs, federal and state financial support of higher education began to resemble many of the characteristics familiar with today's needs. All states were operating public universities, colleges, and community colleges that had tuitions subsidized by state appropriations. The federal government was providing grants to students of all ages based on both merit and need. Also, states also began to develop programs of need-based aid for students to accompany state operating subsidies to institutions (Baum et al., 2013).

Based on these expansions of financial support for higher education during the 1960s and 1970s, state appropriations quickly became a critical source of funding for public postsecondary institutions. By 1980, state appropriations accounted for an average of 44 percent of total revenue. However, this share has steadily declined since, falling to 38 percent in 1990, 32 percent in 2000, 21 percent in 2010, and 17 percent in 2014 (Snyder \& Dillow, 2012; Snyder, 2016). The percentage of federal appropriations has also continued to decline throughout the last 
few decades, falling to approximately 0.51 percent in 2014 (Snyder, 2016). Public appropriations are very reliant on tax revenues and the economy, especially on the state level. Following the U.S. economic recession in the early 1990s, there were significant cuts made in state funding per student; this began to return to near pre-recession levels by the end of the decade, only to be decreased again as a result of the 2008 economic recession (Zusman, 2011).

As public support and funding, primarily from states, has decreased year after year, it has become evident that there is a need for change. While state appropriations once represented a significant proportion of revenue for public higher education institutions, they can now be described as minority partners (Zusman, 2011). Public universities and colleges have found their appropriation dwindling so much that they are "forced to evolve from state-supported to stateassisted to state-related to what might only be characterized as state-located" (Duderstadt, 2007, p. 101).

Tuition. As long as there has been higher education in America, there has always been an obligation of the student to pay a portion of their expenses. The significance of this number has vastly changed over the many centuries and is also highly subjective based on the type of institution. Average tuition at public higher education institutions has remained lower than the average private school tuition dating as far back as mass data collection in 1869-70 (Snyder, 1993).

Based on the lack of available data, most information related to tuition dollars starts in the $20^{\text {th }}$ century. While the 1900 s brought many significant changes regarding funding for higher education, the earliest decades resembled more the past than the present. In 1933, the average public higher education tuition at $\$ 61$ followed previously established trends, remaining lower than private institutions whose average was $\$ 265$. Although the public institution tuition was a 
significant amount of money at the time for lower and middle-class families, the rate of return on a college education was considered high. This was especially true if the youth was in a state with high quality, the inexpensive public system (Goldin \& Katz, 1999).

As state funding continued to decrease through the late $20^{\text {th }}$ century and early 21 st, there was a need to make up for the lost revenue streams. Which often came out of the pocket of students with increases seen in both tuition and fees for more than two-thirds of the nation (Zusman, 2011). In the 20-year span from 1980 to 2000, the percentage of revenue produced from tuition and fees rose from $13 \%$ to $19 \%$ for all public colleges; this rise was even steeper for public non-doctoral baccalaureate institutions (Zusman, 2011). This increase in revenue amounted to an average increase of approximately $\$ 6,000$ per in-state public four-year college student over a thirty-year span ending in 2011. The rate of increase was less extreme at two-year colleges with a 3.4 percent annual increase over the same period (Baum \& Ma, 2011).

It should also be noted that the percentage of revenue represented by tuition and fees is highly contingent on the classification of the university. In 2014, public degree-granting postsecondary institutions earned $20 \%$ of their collective revenue from tuition and fees, whereas private for-profit institutions earned $90.4 \%$ of their collective revenue from this source. During this same time, private nonprofit institutions fell in the middle with $29.6 \%$ of revenue attributable to tuition and fees (Snyder et al., 2016).

Alternative revenues. While public funding and student expenses make up a significant amount of revenue for higher education institutions, it is imperative to look at all sources. As public support continues to decrease, tuition is at an all-time high, and expectations continue to grow, universities must remain vigilant and creative. One source for this revenue is to promote partnerships or endeavors that produce funds to make up for the lack of monies. While this 
seems like a new ideal in higher education, there has long been evidence of just these opportunities (Boehm, 2008).

Since the early 20th century, there has been profit related to auxiliary enterprises. As far back as the thirty-year span from 1910 to 1940 , there was an increase in revenue related to auxiliary enterprises of $12 \%$. Following this period and WWII, there was also a significant shift in revenue related to university hospitals, which saw a significant increase (Snyder, 1993). These are trends that have continued American campuses for decades. In 2013, hospitals and other auxiliary enterprises accounted for close to $18 \%$ of all revenue generated by public institutions. An additional $18 \%$ was also earned by investment returns, gifts, and others of the like (Snyder et al., 2016).

Over the past few decades, outside industries have more than doubled their support for research and development in higher education. In 1980, industry support accounted for a mere four percent of the total percentage of university research dollars, by 2000 this number was almost eight percent (Zusman, 2011). Corporate partnerships are a viable alternative revenue stream, but one that is more difficult to track. Depending on the classification, these monies could be part of the over $\$ 25$ billion generated in sales and services of auxiliary enterprises, $\$ 19$ plus billion in independent operations, or more than $\$ 17$ in other revenues and additions. No matter where this revenue falls, it is evident that it is increasing, reaching a total of over $\$ 5$ billion in voluntary support by 2013-2014 (T. D. Snyder et al., 2016).

Even though higher education is having to operate differently than it was initially intended, these changes allow institutions to continue to think and work outside the box. As early as the turn of the 20th century, the university came to show attributes of a department store, an integrated knowledge-production factory, and a brand name, like what is still seen in today's 
major research universities (Goldin \& Katz, 1999). This idea of operating like a store, or as an identifiable brand has led to unforeseen complexities that will need to continually be addressed moving forward.

\section{Kinesiology in Higher Education}

Kinesiology in higher education has not been immune to the significant changes that have occurred in the American higher education system. It has grown and evolved with the complexities of changing student bodies, societal expectations, and funding allocations (Block \& Estes, 2011). This evolution, in turn, changed the field of kinesiology from one singular focus to a field so fractured at times that it is difficult to classify it as one unit (Newell, 1990). The field works to remain viable and relevant on a continual basis while operating in a world of supercomplexity (Block \& Estes, 2011). As a result of the some of the most recent ebbs, regarding enrollment, expectations, and funding, some professionals in higher education kinesiology have begun to become more entrepreneurial (American Kinesiology Association, 2016a).

History of kinesiology in higher education. In its earliest days, Kinesiology departments in higher education were limited in number with little diversity regarding the types, purpose, and participation. Kinesiology departments began with the primary purpose of preparing physical education teachers and coaches of sport with the necessary technical skills and knowledge (Corbin, 1993). This trend of preparation and classification of higher education kinesiology departments continued through the 1950s. During the golden age of higher education, there was a push to professionalize the field of physical education and as such the field began to expand and grow. This growth took off throughout the 1970s with the expansion 
of new disciplinary classes, including exercise physiology, sport psychology, biomechanics, and motor learning (Henry, 1964).

These fields continued to increase through the 1980s but were still primarily housed under schools of physical education. It was not until the decrease in the demand of teachers that many departments turned to "non-teaching" majors and began referring to their programs as exercise science or kinesiology (Corbin, 1993). Through the next decade, departments began to stray from the traditional title of schools of physical education. Reasons for the changes varied from one institution to the next, for some it was to attract students or grant money, and yet for others, it was due to legislative directives or university acceptance. It seemed that those who were formerly specializing in physical education sought to find a new and more publicly admired or accepted identity (Corbin, 1993).

Most recently the field has struggled with enrollment and justification of programs. The enrollment in physical education teacher education (PETE) programs has decreased significantly throughout the nation, directly impacting many departments and colleges. Also, while exercise science and physiology have not seen the dramatic decrease in numbers of students enrolled, they are not immune to the decrease in overall undergraduate student enrollment seen on American campuses.

\section{Supercomplexity}

Frameworks have long been in existence to help society handle a complex world in which people are assailed by more facts, data, evidence, tasks, and arguments that can easily be handled. While these frameworks have helped those throughout the world, including in higher education, they are now falling short in orienting citizens of a supercomplex world (Barnett, 2000). As society and more specifically higher education continued to progress in relation to 
types, purpose, participation, and funding, it entered an age best described as supercomplexity (Barnett, 2004). One marked by overlapping traditional frameworks that contend and compete with one another in a multifaceted manner (Barnett, 2000).

In a world of supercomplexity, as termed by Barnett (2000) there are radical changes in curriculum design, epistemological, praxis, and ontological elements. As a result of these changes, the curriculum is widening, with an increased range of fields that find themselves worthy of higher education. The fields that for so long have dominated higher education curricula are now more challenged than ever before (Barnett, 2000).

While it is still lesser known than traditional research related frameworks, it has been used to analyze kinesiology in higher education (Block \& Estes, 2011). When applying the supercomplexity framework tenants to higher education and kinesiology in higher education, it becomes challenging to separate them into siloed categories. Often when addressing one area, there is a direct correlation to another area that has overlapping or related characteristics. Despite the challenges of clear separation, Barnett (2004, p. 62) identified the following areas:

- Globalization,

- Digital technologies,

- Interpenetration of wider society,

- $\quad$ Participation, access, and equal opportunities,

- Marketization (identifying knowledge services for potential customers),

- $\quad$ Competition, and

- Systematic quality evaluation.

These elements that influence higher education in an age of supercomplexity create turmoil. They challenge the ways of the past, including the academy, intellectual integrity, 
knowledge production and dissemination, and relationships with all stakeholders (Block \& Estes, 2011). While supercomplexity brings about challenges and change, it is an opportunity for education to reinvent itself and open itself to addressing multiple frameworks of meaning (Block \& Estes, 2011).

Globalization. Higher education in America has always been reliant on the nation it served, but with increasing international communications and connections, it is evident that it must act on a global level. It must adapt to a complex, pervasive, and influential global system to stay viable and profitable (Barnett, 2004). Traditional education that once focused on local and state citizens must stretch beyond the borders and educate the masses, including students from around the world (Welch, 2001). Additionally, researchers and educators must stay connected to colleagues and information from all corners of the globe (Block \& Estes, 2011). Lastly, institutions must continually identify what role higher education plays in an evolving global society (Welch, 2001). While some of these actions are already in place, it is evident that higher education must continue to accept globalization and make fundamental changes to everyday operations (Castells, 1996; Giddens, 1999).

American Higher education and who has access to it, has been changing for as long as it has been in existence. Not only has diversity increased regarding race, gender, and socioeconomic status, but there is also a significant change in nationality. University and college campuses across the nation have continued to increase their international reach through oncampus international students, study abroad programs, and satellite learning. Higher education must accommodate what other countries needs are as well, to reach as many students around the world as possible. As a result of the change in students' location and nationality, the instructional style has been directly impacted. In higher education kinesiology departments there is a continual 
struggle of teaching physical concepts, such as movement and activity, in a non-physical world. Kinesiology professionals must be able to convert their teaching styles so that they translate to distant learners who may access their programs from around the globe. Instructors will also need to ensure their content is relatable and adaptable to diverse contexts, that stretch far beyond the traditional localized context.

In times where monies and resources are limited, it is essential that higher education faculty work in an interdisciplinary fashion that stretches beyond the walls of campuses. Professionals are under immense pressure to produce research on emerging concepts to stay current in the field. They must consider the importance of becoming a global researcher, presenter, and instructor to reach as large of an audience as possible. It is no longer acceptable to silo oneself in the country and field of study they belong; instead, they must bridge connections with any viable options (Tierney, 2001).

What was once clear lines and boundaries between businesses, universities, national economies, and governments, are becoming increasingly more difficult to determine (Welch, 2001). Globalization affects not only what the purpose of higher education is but also how it relates to wider society (Barnett, 2004). The world and current events determine what knowledge is valuable and in turn what may receive attention and funding. Successful faculty members will have to remain cognizant of trends and the effects they may have on their area of expertise (Tierney, 2001).

Digital technologies. As digital technologies continually advance the world of higher education, they also introduce a series of complexities (Barnett, 2004). Digital technologies have transformed the way higher education professionals instruct, research, and communicate with students and colleagues. Kinesiology professionals today must continually walk a fine line 
between integrating technology and not letting it overtake many aspects of the field.

Professionals need to be innovative in their efforts to reach remote learners and captivate their minds. They must seek knowledge from around the world and work on collaboration between fields, institutions, and even countries. Lastly, they must work on communication, how and when it occurs, and whether this fits the needs of modern society.

While distance education has been in existence for hundreds of years, advances in technology have allowed for online learning to become more effective and convenient, increasing popularity. As a result of these advances, there has been in a continual uptick in courses being attended online and a need for professionals to adapt their materials (Ramsey, Hawkins, Housner, Wiegand, \& Bulger, 2009). Currently, one in 14 students enrolled at a public institution is learning entirely online. Additionally, one in every three students participates in online learning at some point during their academic career. The acceptance of online higher education learning has gone mainstream and public, once brick and mortar institutions are working to keep up with massive online for-profit institutions (Hanover Research, 2018). This has led to some issues, regarding assessment, retention, and teacher access (Ramsey et al., 2009). Not only do these issues impact kinesiology programs, but professionals in these fields must also battle with the need to teach physical components through auditory and visual means only.

While universities used to operate in a paradigm of knowledge creation and search for truth, they have now found themselves in a new paradigm more accessible to the general public (Block \& Estes, 2011). This new paradigm consisting of digital technologies has changed the conditions surrounding knowledge, what Barnett (2004) and Bloland (2005) call “epistemological autonomy" or the concept that universities are the source of knowledge creation and therefore the authorities of production and dissemination. Despite this long-held ideal, it is 
the new widespread access to digital technologies and the ability for the masses to search for information that no longer views the academy as knowledge authorities (Block \& Estes, 2011).

Professionals in the field of kinesiology must also consider the changes in production and dissemination of research. Block and Estes (2011), provide insight into a common result of research in the supercomplex world of kinesiology by laying out the following example. No longer can a professor research a topic for the sake of expanding one's mind, but they must also present to peers at conferences, refine and validate the study, and then publish in a peer-reviewed journal. Now, in the world of supercomplexity may require writing results in an electronic newsletter, creating a sound bite for a newscaster, and presenting the research in layperson's terms. Additionally, the professional may also have to address "experts" on social media, monitor for plagiarism, and use the information as follow up for a grant application. Lastly, the information may need to be submitted to an electronic database to monitor faculty productivity (Block \& Estes, 2011).

While beneficial for interacting with colleagues from around the world and supportive of alternative learning environments, technology can also drain time from scholars. In addition to time loss, it has also changed the expansion and production of knowledge (Block \& Estes, 2011). Researchers must now consider not only what is going on in American instructions, but also what has happened in other relatable societies such as the United Kingdom and Australia. While English speaking countries may be easier to synthesize, foreign language research should not be neglected and will still appear in online research endeavors.

Interpenetration of wider society. The interpenetration of higher education institutions with the wider host society is not a new concept, but the degree to which they are intertwined is continually increasing (Boyer, 1990). Universities are no longer considered a separate 
conscience of society; instead, they are an essential part of everyday operations (Block \& Estes, 2011). It is imperative to acknowledge the pressures of a wider society while continuing to remain inflexible and unresponsive to the factors that impact scholarship and professional practice (Block \& Estes, 2011).

The role that universities should play in the wider host society is commonly up for debate. A more liberal view is that universities should play a role that focuses on the balance of power in society. A conservative view highlights the university as part of the capitalist marketplace (Strohl, 2006). These different views on what role higher education should play in society, radically change how universities should function on a daily basis. Universities are continually challenged by the wider society to change teaching methodologies and curricula to meet the needs of a changing student body and societal issues (Block \& Estes, 2011; Hellison, 1987).

While teaching expectations have changed, so too have the concepts of academic freedom and the academic community. These concepts are continually at risk when the wider society defines what knowledge is and who produces it (Block \& Estes, 2011). Autonomy of knowledge has long been the core of higher education, but with a shift of who produces and validates knowledge, this is changing. In the realm of supercomplexity, knowledge is produced by groups based on cultural constructs of the moment, it has become dynamic, and is torn between voices fighting for legitimacy and identity (Block \& Estes, 2011; Tierney, 2001).

As pressures to market products and focus on external stakeholders' interests continue to grow, the line between the search for truth and profit continues to blur (Block \& Estes, 2011). The authority of the academy is continually undermined in a time when many parties can make and claim the truth. Not only do scholars have to propose academic arguments, but they must 
also defend truth and knowledge on multiple levels. For kinesiology professionals to be successful, they must be able to maintain academic integrity, while understanding the needs of society, all while responding to changing expectations of the field (Wilmore, 1998).

Participation, access, and equal opportunities. Another set of complexities for scholars to consider are the agendas of participation, access, and equal opportunity in higher education (Barnett, 2004). The agendas for equal access and opportunity in higher education are imperative, but they do bring forward supercomplex issues on multiple levels. To broaden the access and add diversity to the student body, the makeup of the traditional, modern university student has changed. With changes in participation and opportunity comes the demand for consumer-oriented missions that in turn change the curricular foci (Barnett, 2004; DePauw, 1998; Massengale, 2000). In addition to the changes in curricular direction and foci, are the forces related to open access and stretching already limited resources even further (Milliken, 2004).

Aligned with the goal of increased access to previously limited groups, comes many changes in who is accepted and awarded in higher education. Scholarships are often awarded on ethnicity, socioeconomic status, and interest, rather than on intellect. There are also laws prohibiting faculty and institutions to discriminate or not make reasonable accommodations for students with learning disabilities, closed head injuries, sensory impairments, or other disabilities that impede student success (Block \& Estes, 2011).

In addition to who is accepted, there is also a difference in how that student body is accommodated and instructed. For example, a student body comprising of non-traditional students requires multiple changes in many formally accepted systems. With these new groups, there is a push to extend faculty office hours, offer night and weekend courses, and focus on 
online learning (Hardin, 2008). The line between where high school ends and higher education begins has also become blurred, with institutions offering remedial courses for underprepared students and dual enrollment courses that are accepted as university credit (Block \& Estes, 2011). While these offer challenges to higher education, it also offers a chance to extend the academy into uncharted territory (Block \& Estes, 2011).

While there is not a common argument against creating access for formerly excluded populations, it does change the way higher education institutions function. The concepts of accommodations, access, participation, and opportunity often present additional tasks for scholars to perform. There are parties with special interests that require attention, change in foci, and in some cases, these continue to fragment disciplines (Barnett, 2004).

Like the rest of higher education, kinesiology has seen a change in its consumer base. Kinesiology professionals and the field as a whole need to consider how to teach students from different economic levels, nationalities, races, and genders to lead the field into the future. As enrollment in traditional PETE programs decreases and teaching certification regulations become more complex, the field of kinesiology needs to consider ways to retain populations in similar majors. Programs need to make careers in kinesiology-related fields enticing to learners of all ages to ensure the field remains viable.

Marketization. Whether for better or for worse, it has become clear that in a world of supercomplexity, marketization of higher education plays a crucial role in decision making (Barnett, 2004). Kinesiology scholars have long been encouraged by administrators to become entrepreneurial (Ellis, 1987), as the knowledge generated is a marketable product (Block \& Estes, 2011). Universities often view students as potential customers and knowledge as a product that can be sold and purchased (Barnett, 2004). While there is a range of arguments and methods 
about how higher education institutions should "market" themselves, there is agreement that education has become a commodity that can be marketed (Block \& Estes, 2011). Whether it is through grant dollars from major corporations to conduct research related to specific products (Ellis, 1987) or the pressures related to obtaining federal and state grants, administrators routinely pressure scholars to act as entrepreneurs (Block \& Estes, 2011).

Hermann (2008) believes that universities must be able to manage dependent and integrated teams to continue to move institutions forward. That universities must be able to operate as corporations, with evidence of profitability and performance, expected by multiple investors and stakeholders. There needs to be more pressure on erasing the boundaries between business and higher education with institutions reorganizing, refocusing, and realigning partnerships. Institutions will benefit from looking to the business sector for guidance on how to build and exploit knowledge-based technologies (Hermann, 2008).

Universities are already adopting a handful of corporate traits such as networking. Although there has long been evidence of networking within the academe, it is now time to look externally at the wider global society to increase marketability (Brown, 2008). Higher education institutions are also becoming flexible hybrids, playing the role of both corporate entities and charitable institutions (Cubie, 2008). In addition to these traits, there is an increase in multitasking, laterality, and media capability. They recognize the benefits that relate to the diversity of talent, perspectives and ideas, and the diffusion of knowledge (Hermann, 2008). Lastly, there are partnerships with businesses and universities, which allow for co-creation and sharing of knowledge in many global and public sectors (Hermann, 2008).

With a consistently growing focus on public health and activity, it is evident that knowledge from the kinesiology world plays an integral role in the market. Many kinesiology 
departments provide a clear representation of the supercomplex nature of higher education as a whole. The discipline as it stands today is made up of a variety of professionals and fields that must all interact together and with wider society. Kinesiology departments will have to hire administrators and faculty who not only understand the content and knowledge from within the classroom but also their role of scholarship in a world of supercomplexity. Those professionals who insist on traditional forms of education that do not stretch beyond the classroom and office doors will soon find themselves unsuccessful (Block \& Estes, 2011).

Competition. With increased focus on profits and students as consumers, competition for clientele and funds within higher education is rapidly increasing (Barnett, 2004). Universities are competing on a daily basis for resources, grants, programs, faculty, students, prestige, and even knowledge (Barnett, 2004, 2005; Bloland, 2005; Milliken, 2004; Sage, 1987; Wills, 2018). Universities must define their niche and construct missions that attract students and stakeholders to thrive in a highly competitive market.

Mission identity has become a keystone of universities, as for how they are defined no longer a given, instead it is constructed on a needs basis (Barnett, 2005). Universities who create and market popular missions and brands are more successful in the wider society. These missions are seen to increase student enrollment, the share of state and federal resources, high profile faculty, and in turn grant dollars. In addition to these more tangible examples, there is also competition related to knowledge itself and producing graduates who can apply this knowledge in a global, digitalized society (Krahenbuhl, 1998).

The competition for knowledge itself adds another layer to an already supercomplex world of higher education. With the increased access to knowledge, there has in turn been a rise in doubt and questions regarding information from experts (Bloland, 2005). For centuries, 
universities operated in a realm in which they had a monopoly of knowledge, but this is no longer the case. With expanded access to knowledge from multiple sources, consumers do not rely on higher education to define what is important (Bloland, 2005).

With these complexities in mind, it is evident that a single discipline is not sufficient in examining the complex issues of modern society. Scholars need to work with colleagues and professionals across disciplinary lines and outside of institutions to improve conflicting knowledge and messages (Tierney, 2001). This interdisciplinary approach will prove to be more successful (DePauw, 1998) than the compartmentalizing of subdisciplines that have arisen in the past decades (Burt, 1987). By fields of study becoming more flexible and issue-focused, rather than siloed by discipline, there would be a higher probability of survival in an ultra-competitive environment (Mourad, 1997). Programs that are fluid, transformative, and dynamic will remain competitive, those that in inflexible and nonreflexive will fall by the wayside (Mourad, 1997).

Universities need to look past the traditional, narrow frames of reference. The profession needs to construct an applied mission, with collaboration, guiding research, and innovative pedagogical practices (Hellison, 1987). In a fluid and competitive market, it is essential that universities erase the boundaries between knowledge, research, and teaching to ensure overall success (Hellison, 1987; McNeil, 1987; Mourad, 1997).

Systematic quality evaluation. The age of epistemological autonomy in higher education is no more, with quality evaluation seen at every level and in every discipline (Bloland, 2005). Systematic evaluations developed at the state and national level have become pervasive at universities. These evaluations provide oversight of what is occurring in and out of the classroom for all education stakeholders (Barnett, 2004). One reason for an increase in evaluations includes an increased lack of confidence in the academy (Barnett, 2004). This lack of 
confidence stems from the inability of universities to address all the concerns of the wider society.

Quality evaluation in higher education happens on many levels; there are federal mandates that assess whether institutions are meeting the designated "grade" related to their performance and national governing bodies related to particular fields of study. Federal and regional accrediting associations are continually evaluated thousands of indicators to ensure higher education institutions are doing what they set out to do. Most recently there has been a push for outcomes assessment and accountability by several regional accrediting associations. In addition to broad quality evaluation, there is also evaluation of students, faculty, and programs on campuses. In an age of oversight, complication, and competition, it is only becoming more common for quality assurance to be a cyclical process that all stakeholders are a part of (Astin \& Antonio, 2012).

The discipline of kinesiology has been modestly flexible and reflexive with the trends of quality assurance and assessment. Many disciplines housed under the kinesiology field have created national standards and outcomes to address the expectations of external stakeholders. These, in turn, support what is focused on in the classroom and provides a baseline for knowledge generation. There are also additional standards created by states/regions and private parties (commissions/associations). It is the latter that can be most challenging to incorporate as they often have accountability measures that were influenced by special interests. It is crucial that kinesiology scholars continually engage in research and conversations concerning quality assurance, to ensure that it is beneficial to those in the field and the future of the field (Block \& Estes, 2011). 


\section{Entrepreneurial Initiative}

While entrepreneurial initiative may seem like a new concept, it is evident that being innovative in higher education has always been crucial. For hundreds of years, faculty has needed to embrace innovation, experimentation, and new initiatives. In most recent years, there has been a transition from not only focusing on these areas but also profiting (Boehm, 2008). Today's complexities regarding decreasing public revenues, pressures to freeze increasing student tuition, and ballooning expenditures (Zusman, 2011) lead to an opportunity to stray from traditional revenues and instead explore new educational revenues.

New educational revenues. One way to profit from entrepreneurial initiatives is the attempt to capture or cater to high-growth student populations. These populations include nontraditional aged learners, international students, distance learners, and working professionals. In addition to embracing unique students, faculty must stretch themselves past their traditional teaching roles into innovative frontiers. These may include mass course and curriculum creation, testing and certification processes, and private consulting (Educational Advisory Board, 2013).

One of the most traditional forms of focused revenue generation is by recruitment. While efforts may have traditionally been made with high school aged students, it is imperative that these be streamlined through the expertise of third-party recruitment agencies, pathway programs, and even unique incentives for students. One benefit of using third-party recruitment agencies is their expertise and ability to cater to the consumer. Despite technological advances, it is still evident that colleges rely on websites and email to recruit students, even with nontraditional learners (The National Association for College Admission Counseling [NACAC], 2018). It is imperative that these tools be used frequently and correctly throughout the recruitment process in order to enhance the chance of enrollment. Third-party agencies may also 
offer non-traditional ideas of recruitment that center on community college teams and the use of faculty (Educational Advisory Board, 2013). Another option for recruitment is through pathway programs, which have continued to increase as the growth of international student mobility has risen to over 4.5 million students studying abroad (Biesheuvel, Jansen, Johnson, \& Neghina, 2015). Pathway programs in part address concerns related to recruitment and retention with nontraditional learners by assisting students with the language proficiency and familiarization of socio-cultural norms of the context into which they are transitioning (Biesheuvel et al., 2015). Often universities will partner with corporations that specialize in pathway programs as they can be difficult and expensive to engage in independently (Agosti \& Bernat, 2018). Additionally, there is the idea of incentives that can be used to entice students, such as prepaid international phone plans. While this seems simple on the surface, its complexities would be best handled by professional recruitment agencies.

The typical higher education school year in America has made most of its revenue through only two semesters. By stretching into non-traditional semesters, such as summer and intersession, there is an increase in the ability to market to a variety of consumers and generate revenue year-round. Higher education institutions can begin to use what are often resting periods in academia to fulfill needs on their campuses. Techniques may include focusing on highdemand courses and majors by offered additional course sections in the summer and winter or prerequisite fulfillment opportunities. These non-traditional sessions can also focus on open enrollment and drop stricter student registration requirements to increase student populations on campus (Educational Advisory Board, 2013).

As technology in education advanced, so did distance learning opportunities (Hanover Research, 2018). This increase led to creativity regarding agreements programs, enrollment, and 
even location of the attendee. One example of agreement programs regarding the location of the learner is out-of-state programs being offered by community colleges. There is also the notion of students receiving in-state tuition rates despite being located elsewhere, also known as the academic common market. The academic common market allows college students who want to pursue degrees not offered in their home state to pay in-state tuition at another institution. Both undergraduate and graduate degrees are offered through regional partnerships (Southern Regional Education Board, 1974). There is also the opportunity to teach students who may be enrolled elsewhere, such as in high school, through dual enrollment programs. By allowing students to enroll, the consumer base increases in size, and there is also the ability to sell a product for what may end up being a longer duration of time (UPCEA, 2018).

Another student population that is now being tapped into is working professionals who are continuing their education. While traditional educational frameworks and curricula may have once been too rigid for them, they now can attain degrees through applied and professional programs, that can be attended while maintaining full-time employment (Educational Advisory Board, 2013). It is this population in part, that has turned online learning into a mainstream concept with one in every 14 students at public, four-year school being fully distance learners (Hanover Research, 2018). Also, to entirely distance learners, it has also been estimated that one in three students are enrolled in courses online at one point in their academic career (Hanover Research, 2018). Traditional institutions are continuing to expand their micro-credential offerings, to capitalize on the massive consumer base related to online and non-traditional higher education (Hanover Research, 2017). Some programs allow students to take open online courses and count them as a free-standing credential or use the credit towards a full master's program at participating institutions (Hanover Research, 2017). While online learning may have once been 
questioned for its validity, the costs and ease of use are changing the landscape for nontraditional learners (Hanover Research, 2017).

In addition to individualized applied work, there is also a market for education to work in a more corporate setting. By expanding into corporations, institutions can provide tailored company education initiatives (Educational Advisory Board, 2013). The great divide and more recently the question of the value of the higher education can be in part addressed by more corporate partnerships. Corporations can team up with higher education institutions to create incentives for employers to enroll in continuing education programs or just free-standing coursework related to the job. It has been found in recent studies that employers positively view applicants who recently completed job-related MOOCs (Hanover Research, 2017). The next step would be for corporations to recommend online courses to employees or even partner with institutions to create tailored educational experiences. These courses could then be taken as part of the training process, onsite, or after-hours depending on the model adopted (Educational Advisory Board, 2013).

Lastly, there is the notion of learning being a lifetime venture which leads to the opportunity for seniors' enrichment programs. Although this is not traditional learning, tied to grades and degrees, it is still financially beneficial to institutions to cater to a growing and aging population (Educational Advisory Board, 2013). Some program example ideas could be expanded the ability to audit courses and adjusted related fees. Capitalizing on weekend-long excursions that can be tied to learning. Faculty-led destination travel, similar to the growing study abroad with younger generations, this could be of varying lengths. There could also be ventures related to college-affiliated retirement communities. 
In addition to capturing high-growth student populations, it is also imperative that higher education faculty think of marketable uses for their knowledge and expertise. One possible avenue for this is to create curricula that can be sold to others in a turnkey fashion, as well as even just courses that can be profited from (Educational Advisory Board, 2013). One example of this process is through MOOCs, which are created by one institution then accessed around the world (Ho et al., 2015). Higher education faculty should be purposeful when creating their teaching materials, to allow for ownership and the ability to mass produce and turn a profit. Faculty who are experts in education could create homeschool materials for statewide programs. Unique learning opportunities such as capstones could be created and sold to other institutions looking for similar ventures but currently lacking resources. Lastly, courses could be sold to international markets, that are expanding at exponential rates (Chapman \& Austin, 2002). Course creation should never remain bound to the creator or their institution; it should be marketed in a similar way as other inventive ideas and products.

As quality evaluation continues to hold such a relevant role today, it is also important to market oneself related to testing and certification areas. This may be related to test creation, preparation, or evaluation, all of which can be extremely profitable (Educational Advisory Board, 2013). Higher education institutions can create opportunities for revenue related to professional society testing partnerships. Institutions or faculty who may be considered the field of study experts may be utilized by outside parties to create testing materials and guidelines. Monies can also be generated on campus through ESL testing for international applicants and current students, as well as placement testing. Often colleges require placement testing to occur for courses or programs, but at times these are free of charge. It may be beneficial to market such exams like other standardized testing corporations to generate revenue. 
Lastly, there is the area of faculty consulting. Despite the ongoing battle for knowledge creation, the majority is still created and disseminated through the ivory towers. Therefore it is essential to utilize this knowledge, through avenues such as consulting (Educational Advisory Board, 2013). Higher education institutions may benefit financially from international curriculum consulting in expanding educational countries. Faculty can also generate revenue through expertise database creation. There are also opportunities related to capstone-projects and partnering with industries who will sponsor extraneous costs.

Academic entrepreneurship infrastructure. Not only is it essential to be open to nontraditional and innovative opportunities related to revenue generation, but it is also imperative to have the infrastructure to take on these endeavors. In order to implement changes related to new educational revenues, an institution must consider the support systems present, as well as the ability to develop and manage any newly created ventures. Particular areas that are critical for identifying, launching, and scaling viable programs include planning support, marketing, curriculum development, management, and outsourcing (Educational Advisory Board, 2013).

One of the first areas to consider is the supports related to business planning. Specifically, higher education institutions need to consider training faculty and staff in entrepreneurial initiatives and management related to startup tasks. Typical faculty members in higher education do not have a business background and thus will need to be trained related to starting business ventures. Due to the bureaucracy often involved in higher education, it may be beneficial to provide faculty with program approval maps, or a guide to how to begin a venture (Hendrickson et al., 2013). Institutions may invest in program development office staff and support to continue to support faculty through the planning stages of entrepreneurial tasks. It may even be helpful to train faculty on the basics of entrepreneurship and innovative thinking, to show them their 
capabilities related to revenue generation that may be currently overlooked (Educational Advisory Board, 2013).

It can also be advantageous to consider programs that can launch at a faster than the standard rate. The traditional pathway of new courses and degrees in institutions can be bogged down throughout many parts of the bureaucratic process, so it may be essential to work creatively to launch new ventures. This may be working through certificate programs or schools of continuing education which may have less red tape involved with product launches. Institutions who have innovation labs or incubators, or even successful business programs, may be able to facilitate program launches (Educational Advisory Board, 2013).

In starting new initiatives, it is also essential to consider cost-effective marketing strategies. At the end of the day, the idea is to make a profit, so upfront costs should be kept to a minimum as much as possible. This can be done through convenience, such as partnerships related to the audience that is being recruited. Marketing in today's higher education market is essential, both on and off campus, and there are many innovative ways to access and entice populations that surpass the pamphlets of past decades. Higher education professionals are finding Generation Z, the current college-age student population, expects innovative methods of marketing. One example that helps students connect and become consumers is through virtual reality, with higher education institutions offering tours of facilities and more (Hanover Research, 2018). Even students of a non-traditional age expect seamless marketing with the ability to interact with websites easily and from anywhere (Hanover Research, 2018).

Curriculum development is essential to create a product that stands out against competitors. While it should not be overlooked, it must also not become the whole focus, as the process of creation can be slowed to a halt in this stage. Higher education institutions should 
consider their abilities to create or implement innovative instruction. Universities need to consider the abilities of instructional design experts, to ensure online learning and online platforms are highly functional. They could also benefit from having mini-lectures or teamteaching opportunities in place that can be utilized by instructors and faculty throughout the institution. This will allow for efficiency and consistency, which are often lacking in higher education (Educational Advisory Board, 2013).

Another critical area of infrastructure relates to enrollment. Numbers of students and new populations will need to be forecasted, controlled, and then managed properly. Institutions may need to hire additional staff and faculty to please new audiences and ensure there is retention of the student populations. Total enrollments in higher education have continued to decline over the past several years (Hanover Research, 2017), so it is essential to track lucrative populations and programs. Higher education institutions may need to rely on research by third parties, such as Hanover Research or the Educational Advisory Board, to begin to tailor future opportunities as early as possible. No longer can institutions rely on the idea that the consumer will always be there, rather they must cater to that consumer and entice them to arrive.

Lastly, higher education institutions must be realistic about their capabilities. They must be forward thinking about partnerships that can be achieved and what must be outsourced to be successful. In addition to not only realizing this avenue, higher education institutions must work on these relationships to ensure new programs do not fall through the cracks. Higher education institutions may benefit from joint ventures that alleviate pressures often felt on campus (Educational Advisory Board, 2013). 


\section{Entrepreneurial Initiatives in Kinesiology}

To cope with the supercomplexities of higher education, as well as the pressures and constraints of an ever-intrusive wider society, leaders in kinesiology must be innovative and entrepreneurial. In recent years, the governing bodies of the field, including the American Kinesiology Association (AKA) have focused on entrepreneurial concepts at national conferences. These concepts include non-traditional revenues that currently exist in higher education kinesiology programs and increasing external funding.

While there is little research related to entrepreneurial initiatives and their impact on the field of kinesiology, there is a discussion about such initiatives occurring. In 2016, one of the foci of the AKA Leadership conference was entrepreneurial opportunities that were already in existence and could be replicated in other higher education settings. These opportunities varied from corporate partnerships to grassroots efforts by departments. Some schools created revenue streams through camps or youth programs, new degrees on campus, certification programs, and biometric laboratories. While some of these outlets drive in more revenue than others, the commonality was the importance of creating a culture of innovation and entrepreneurship (American Kinesiology Association, 2016a).

It is imperative that kinesiology programs instill a culture related to innovation and entrepreneurship in order to be successful in driving alternative revenue streams. Departments of kinesiology need to consider what supports and infrastructure are in place at multiple levels to ensure efforts are given a chance to thrive. In a second session of the same conference 2016, presenters speaking about these supports and infrastructure recognized the importance of strategic planning, evaluation, and expectations (American Kinesiology Association, 2016b). External and nontraditional revenue will be essential moving forward in a supercomplex system 
with limited resources, and all higher education kinesiology professionals will need to consider the feasibility of planned endeavors.

Higher education and kinesiology are continually changing and will no longer be able to operate like past several decades. Kinesiology professionals need to consider the many variables that must be addressed simultaneously in a supercomplex environment. Currently, there are significant issues related to funding and enrollment, and entrepreneurial initiatives offer options to address these issues. The purpose of this exploratory study is to (a) gain a consensus of expert opinion from leaders in kinesiology departments regarding the impact and feasibility of entrepreneurial initiatives in higher education, and (b) to generate a list of facilitators and barriers that may impact implementation of entrepreneurial initiatives in their departmental context. The supporting research questions are as follows:

1. What is the perceived impact and feasibility of selected entrepreneurial initiatives for higher education kinesiology departments?

2. What is the consensus of expert opinion regarding the most impactful and feasible entrepreneurial initiatives for higher education kinesiology departments?

3. What are some facilitators and barriers that to implementation of entrepreneurial initiatives? 


\section{References}

Adler, M., \& Ziglio, E. (1996). Gazing into the oracle: The Delphi method and its application to social policy and public health. London: Jessica Kingsley Publishers.

Agosti, C. I., \& Bernat, E. (2018). University pathway programs : Types , origins , aims and defining traits. In C. I. Agosti \& E. Bernat (Eds.), University pathway programs: Local responses within a growing global trend (pp. 3-25). Springer International Publishing AG.

American Kinesiology Association. (2016a). Entrepreneurial opportunities. In AKA Leadership Workshop. Phoenix, AZ.

American Kinesiology Association. (2016b). Increasing external funding. In AKA Leadership Workshop. Phoenix, AZ.

American Kinesiology Association. (2019). About AKA: Definition of kinesiology. Retrieved from http://www.americankinesiology.org/SubPages/Pages/About

Astin, A. W. (1998). The changing American student: Thirty-year trends, 1966-1996. The Review of Higher Education, 21(2), 115-135.

Astin, A. W., \& Antonio, A. L. (2012). Assessment for excellence: The philosophy and practice of assessment and evaluation in higher education. Lanham: Rowman \& Littlefield Publishers Inc.

Authur-Banning, S. (2018). Youth sports in America: the most important issues in youth sports today. (P. B. Greenwood \& M. S. Wells, Eds.). Santa Barbara, CA: ABC-CLIO, LLC.

Barnett, R. (2000). Supercomplexity and the Curriculum. Studies in Higher Education, 25(3), 255-265. https://doi.org/10.1080/713696156

Barnett, R. (2004). The Purposes of Higher Education and the Changing Face of Academia. London Review of Education, 2(1), 61-73. https://doi.org/10.1080/1474846042000177483 
Batten, D. D. (2011). The G.I. Bill, higher education and American society. Grove City College Journal of Law \& Public Policy, 2(1), 13-30.

Baum, S., \& Ma, J. (2011). Trends in college pricing 2011. New York, New York. Retrieved from http://trends.collegeboard.org/sites/default/files/trends-college-pricing-web-final-5082.pdf

Baum, S., \& Payea, K. (2014). Trends in student aid 2012. New York. Retrieved from http://trends.collegeboard.org/sites/default/files/student-aid-2013-fullreport.pdf\%5Cnpapers2://publication/uuid/74B810D6-8F4C-4D9E-860C-E5FE702152FD

Baum, Sandy, Kurose, C., \& McPherson, M. (2013). An overview of American higher education. The Future of Children, 23(1), 17-39. https://doi.org/10.1353/foc.2013.0008

Biesheuvel, W., Jansen, R., Johnson, N., \& Neghina, C. (2015). New routes to higher education: the global rise of foundation programmes. Retrieved from http://www.studyportals.com/intelligence/foundation-programmes/

Block, B. A., \& Estes, S. (2011). Supercomplexity in higher education kinesiology. Quest, 63(2), 179-196. https://doi.org/10.1080/00336297.2011.10483675

Bloland, H. G. (2005). Whatever happened to postmodernism in higher education? No requiem in the new Millennium. Journal of Higher Education, 76(2), 121-150.

Boehm, J. (2008). Entrepreneurial Orientation in Academia (1st Editio). Germany: Springer Science+Business Media.

Bowen, W. G. (2012). The 'cost disease'in higher education: is technology the answer? The Tanner Lectures Stanford University, (October). Retrieved from http://new.oberlin.edu/dotAsset/a0e24144-e4f3-48fc-b856c407ff37b50e.pdf\%5Cnpapers3://publication/uuid/7C85F2C6-3160-4D73-8828- 


\section{EF35ECDD796B}

Boyer, E. L. (1990). Scholarship reconsidered: Priorities of the professoriate. Lawrenceville, New Jersey: Princeton University Press.

Brint, S., Turk-bicakci, L., \& Levy, C. S. (2016). From the Liberal to the Practical Arts in American Colleges and Universities : Organizational Analysis and Curricular Change Author ( s ): Steven Brint, Mark Riddle, Lori Turk-Bicakci and Charles S . Levy Published by : Ohio State University Press Stabl, 76(2), 151-180.

Brooks, K. W. (1979). Delphi technique: Expanding applications. No Central Assoc Quarterly, $53,377-385$.

Brown, R. (2008). What will successful organizations look like? In K. Herrmann, R. Brown, \& S. Scott-Davies (Eds.), Leadership in an age of supercomplexity: Challenges for 21st century universities and businesses (pp. 11-13). London: Council for Industry and Higher Education.

Bulger, S. M., \& Housner, L. D. (2007). Modified Delphi Investigation of Exercise Science in Physical Education Teacher Education. Journal of Teaching in Physical Education, 26, 5780.

Burt, J. (1987). Three dreams: The future of HPERD at the cutting edge. In J. D. Massengale (Ed.), Trends toward the future in physical education (pp. 153-168). Champaign, IL: Human Kinetics Publishers, Inc.

Castells, M. (1996). The information age: Economy, society, and culture. Oxford: Blackwell Publishers.

Chapman, D. W., \& Austin, A. E. (2002). Higher education in the developing world: Changing contexts and institutional responses. (P. G. Altbach, Ed.). Westport: Greenwood Press. 
Cheslock, J. J., \& Knight, D. B. (2015). Diverging Revenues, Cascading Expenditures, and Ensuing Subsidies: The Unbalanced and Growing Financial Strain of Intercollegiate Athletics on Universities and Their Students. The Journal of Higher Education, 86(3), 417447. https://doi.org/10.1353/jhe.2015.0017

Christensen, C. M., \& Eyring, H. J. (2011). The innovative university: Changing the DNA of higher education from the inside ou. John Wiley \& Sons. https://doi.org/10.5465/amle.2013.0301

Clark, D. A. (1998). The two Joes meet- Joe college, Joe veteran: The GI Bill, college education, and postwar American culture. History of Education Quarterly, 38(2), 165-190.

Clayton, M. J. (1997). Delphi: a technique to harness expert opinion for critical decision-making tasks in education. Educational Psychology, 17(4), 373-386. https://doi.org/10.1080/0144341970170401

College of Education at The University of Texas at Austin. (2019). Fitness Institute of Texas: History of FIT. Retrieved from http://sites.edb.utexas.edu/fit/history-of-fit/

Corbin, C. B. (1993). Clues from dinosaurs, mules, and the bull snake: Our field in the 21st century. Quest, 45(4), 546-556. https://doi.org/10.1080/00336297.1993.10484105

Cubie, A. (2008). The 'business' dimensions of higher education. In K. Herrmann, R. Brown, \& S. Scott-Davies (Eds.), Leadership in an age of supercomplexity: Challenges for 21st century universities and businesses (pp. 14-16). London: Council for Industry and Higher Education.

Delbecq, A. L., \& Van de Ven A, G. D. (1975). Group Techniques for Program Planning: A Guide to Nominal Group and Delphi Processes. Glenview, IL: Scott, Foresman, and Company. 
Deming, D., Goldin, C., Katz, L., Deming, D., Goldin, C., \& Katz, L. (2018). For-Profit Colleges, 23(1), 137-163.

DePauw, K. P. (1998). Futurisktic perspectives for kinesiology and physical education. Quest, $50,1-8$.

Educational Advisory Board. (2013). Alternative revenues in higher education, 1.

Ellis, M. (1987). The business of physical education. In J. D. Massengale (Ed.), Trends toward the future in physical education (pp. 69-84). Champaign, IL: Human Kinetics Publishers, Inc.

Elwood, T. W. (2013). The changing landscape of higher education. Journal of Allied Health, $42(2), 63$.

Frederiksen, C. F. (1993). A brief history of collegiate housing. In R. B. Winston, S. Anchors, \& Associates (Eds.), Student housing and residential life (pp. 167-183). San Francisco, CA: Jossey-Bass.

Giddens, A. (n.d.). The Great Globalization Debate, Zellerbach Distinguised Lecture, University of California, Berkeley.

Goldin, C., \& Katz, L. F. (1999). The shaping of higher education: The formative years in the United States, 1890 to 1940. Journal of Economic Perspectives, 13(1), 37-62. https://doi.org/10.1257/jep.13.1.37

Hanover Research. (2017). Hanover Research 2017 industry trend report. Arlington, VA. Hanover Research. (2018). Trends in higher education 2018. Arlington, VA.

Hardin, C. J. (2008). Adult Students in Higher Education: A Portrait of Transitions. New Directions for Higher Education, (144), 49-27. https://doi.org/10.1002/he

Hellison, D. (1987). Dreaming the possible dream: The rise and triumph of Physical Education. 
In Trends towards the future of Physical Education (pp. 137-151). Champaign: Human Kinetics.

Hendrickson, R. M., Lane, J. E., Harris, J. T., \& Dorman, R. H. (2013). Academic leadership and governance of higher education: A guide for trustees, leaders and aspiring leaders of twoand four-year institutions. Sterling, Virginia: Stylus Publishing.

Henry, F. M. (1964). Physical education: An academic discipline. Journal of Health, Physical Education, and Recreation, 35(7), 32-33.

Herrmann, K. (2008). Leadership in an age of supercomplexity. In K. Herrmann, R. Brown, \& S. Scott-Davies (Eds.), Leadership in an age of supercomplexity: Challenges for 21st century universities and businesses (pp. 7-10). London: Council for Industry and Higher Education. Ho, A. D., Chuang, I., Reich, J., Coleman, C. A., Whitehill, J., Northcutt, C. G., ... Petersen, R. (2015). HarvardX and MITx : Two Years of Open Online Courses Fall 2012-Summer 2014. SSRN Electronic Journal, (10), 1-37. https://doi.org/10.2139/ssrn.2586847

Hofstadter, R., \& Hardy, C. D. (1952). The development and scope of higher education in the United States. New York, New York: Columbia University Press.

Jacobs, J. M. (1996). Essential assessment criteria for physical education teacher education programs: A Delphi study (doctoral disseration, West Virginia University). Dissertation Abstracts International, 57, 2938.

Kazdin, A. E. (2011). Single-case research designs (2nd ed.). Ozford University Press.

Krahenbuhl, G. S. (1998). Higher Education in the 21st Century : The Role of Kinesiology and Physical Education. World Health, 6297(February), 108-115. https://doi.org/10.1080/00336297.1998.10484267

Lanford, H. W. (1972). Technological forecasting methodologies: A synthesis. New York, New 
York: American Management Association, Inc.

Lee, G. C. (1963). The Morrill act and education. British Journal of Educational Studies, 12(1), 19-40. https://doi.org/10.1080/00071005.1963.9973102

Lierman, W. (1996). Euro Delphi: A comparative study on the future of adult education in 14 countries between 1993 and 1995. Journal of Lifelong Education, 15, 125-138.

Massengale, J. D. (2000). Doing PE at the new university. Quest, 52, 102-109. https://doi.org/10.1007/s11423-011-9194-5

McNeil, A. (1987). Wellness programs and their influence on professional preparation. In J. D. Massengale (Ed.), Trends toward the future in physical education (pp. 85-94). Champaign, IL: Human Kinetics Publishers, Inc.

Meyer, A. E. (1975). Grandmasters of educational thought. New York, New York: McGraw Hill.

Miller, M. T., \& Husmann, D. E. (1994). Strategies for improving instructional delivery in distance education programs. Journal of Adult Education, 22, 23-29.

Milliken, J. (2004). Thematic reflections on higher education. Higher Education in Europe, 29(1), 9-18. https://doi.org/10.1080/03797720410001673265

Mourad, R. (1997). Postmodern philosophical critique and the pursuit of knowledge in higher education. Westport, CT: Bergin \& Garvey.

Murry, J. W., \& Hammons, J. O. (1995). Delphi: A Versatile Methodology for Conducting Qualitative Research. The Review of Higher Education, 18(4), 423-436. https://doi.org/10.1353/rhe.1995.0008

Newell, K. (1990). Physical education in higher education: Chaos out of order. Quest, 42(227242). 
Parentè, F. J., \& Anderson-Parentè, J. (1987). Delphi inquiry systems. In G. Wright \& P. Ayton (Eds.), Judgmental Forecasting (pp. 129-156). New York, NY: John Wiley \& Sons.

Ramsey, C., Hawkins, A., Housner, L. D., Wiegand, R. L., \& Bulger, S. M. (2009). Finding the recipe for the best blend: The evolution and assessment of a blended Master's degree program. Journal of the Research Center for Educational Technology, 5(2), 3-26.

Sage, G. (1987). The future and the profession of physical education. In J. D. Massengale (Ed.), Trends towards the future of Physical Education (pp. 9-23). Champaign, IL: Human Kinetics, Inc.

Sandrey, M. a, \& Bulger, S. M. (2008). The Delphi Method: An Approach for Facilitating Evidence Based Practice in Athletic Training, 3(4), 135-142.

Serow, R. C. (2004). Policy as symbol: Title II of the 1944 G.I. Bill. The Review of Higher Education, 27(4), 481-499.

Slaughter, S. (1998). Federal policy and supply-side institutional resource allocation at public research universities. The Review of Higher Education, 21(3), 209-244.

Smith, C. L. (1992). National issues and concerns in marketing teacher education. Marketing Educators' Journal, 30, 75-89.

Snyder, T. D., de Brey, C., \& Dillow, S. A. (2016). Digest of education statistics 2015. Washington, DC. https://doi.org/10.5860/CHOICE.51-5366

Snyder, T. D., \& Dillow, S. A. (2012). Digest of education statistics 2011. Digest of education statistics 2011. https://doi.org/NCES 2012-001

Snyder, Thomas D. (1993). 120 years of American education: A statistical portrait. Statistics. Retrieved from http://nces.ed.gov/pubs93/93442.pdf

Snyder, Thomas D. (2016). Digest of educational statistics 2016. Washington, DC. Retrieved 
from https://nces.ed.gov/programs/digest/d16/index.asp

Snyder, Thomas D, \& Hoffman, C. M. (2002). Digest of education statistics 2001. Washington, DC. https://doi.org/10.1037/e492182006-003

Southern Regional Education Board. (1974). The academic common market, 22.

Strohl, N. M. (2006). The postmodern university revisited: reframing higher education debates from the 'two cultures' to postmodernity. London Review of Education, 4(2), 133-148. https://doi.org/10.1080/14748460600855195

Tesch, R. (1990). Qualitative research: Analysis types and software tools. New York: Falmer Press.

Tewksbury, D. (1965). The founding of American colleges and universities before the Civil War: with particular reference to the religious influences bearing upon the college movement. New York, New York: Archon Books. Retrieved from http://www.tcrecord.org/Content.asp?ContentID=12572

The National Association for College Admission Counseling. (2018). 2017 state of college admission. The Journal of College Admission, (238), 24.

Tierney, W. G. (2001). The autonomy of knowledge and the decline of the subject: Postmodernism and the reformulation of the university. Higher Education, 41(4), 353-372.

Toby, J. (2010). How scholarships morphed into financial aid. Academic Questions, 23(3), 298310.

Trow, M. A. (2006). Reflections on the transition from elite to mass to universal access: Forms and phases of higher education in modern societies since WWII. In J. Forest, James \& G. Altbach, Philip (Eds.), International Handbook of Higher Education (pp. 243-280). Dordrecht: Springer. 
U.S. Department of Commerce, B. of the C. (1975). Historical statistics of the United States from colonial times to 1970. Washington, DC.

UPCEA Hallmarks of success in professional and continuing education. (2018). Washington, DC.

Vagias, W. M. (2006). Likert-type scale response anchors. Clemson International Institute for Tourism and Research Development, Department of Parks, Recreation and Tourism Managment., 3-4. https://doi.org/10.1525/auk.2008.125.1.225

Veysey, L. (1965). The emergence of the American research university. Chicago, Illinois: University of Chicago Press.

Welch, A. R. (2001). Globalisation, post-modernity and the state: Comparative education facing the third millennium. Comparative Education, 37(4), 475-492.

Wills, J. E. (2018). The post-postmodern university. Change, 27(2), 59-62.

Wilmore, J. H. (1998). Building strong academic programs for our future. Quest, (50), 103-107.

Zusman, A. (2011). Challenges facing higher education in the twenty-first century. In P. G. Altbach, P. J. Gumport, \& R. O. Berdahl (Eds.), American Higher Education in the TwentyFirst Century: Social, Political, and Economic Challenges (pp. 115-160). Baltimore, Maryland: JHU Press. 


\section{Appendix B: Definition of Key Terms}

For the purpose of this study, the following terms were defined as:

Consensus: Gathering of individual evaluations around a median response, with minimal divergence (Brooks, 1979). For this study, a consensus will be achieved when an item obtains the same rating of impact and feasibility from $75 \%$ of the participants (Jacobs, 1996).

Delphi Method: A structured process of knowledge collection and distillation from a group of experts using a series of questionnaires and controlled feedback (Adler \& Ziglio, 1996). This group communication process allows a group of knowledgeable individuals to reach a consensus when available information is incomplete (Clayton, 1997).

Entrepreneurial Initiative: The act of taking financial risks in the hope of profit before others have an opportunity to. In reference to higher education, institutions must embrace innovation, experimentation, and new initiatives, and its leaders much have the skills and imagination to facilitate responsible change (UPCEA, 2018).

Expert: An individual that has a high level of knowledge or practical engagement with problems being studied (Adler \& Ziglio, 1996). Nominations of well-known and respected individuals from members of the selected target group will be used to form the basis of the panel (Clayton, 1997). For this study, the panel will consist of leaders in higher education kinesiology who meet established criterion in the area leadership, budgeting knowledge, and innovation.

Higher Education: A term that will be used to identify a variety of post-secondary learning institutions. The term includes universities, colleges, two-and-four-year, online, brick and mortar, and public and private institutions.

Kinesiology: An academic discipline which involves the study of physical activity and its impact of health, society, and quality of life. It includes, but is not limited to biomechanics, 
strength and conditioning, sport psychology, physical activity, physical education teacher education, sport and exercise physiology, or exercise science (American Kinesiology Association, 2019).

Supercomplexity: An age that is marked by overlapping traditional frameworks that contend and compete with one another in a multifaceted manner (Barnett, 2000). 


\section{Appendix C: Research Method Flowchart}

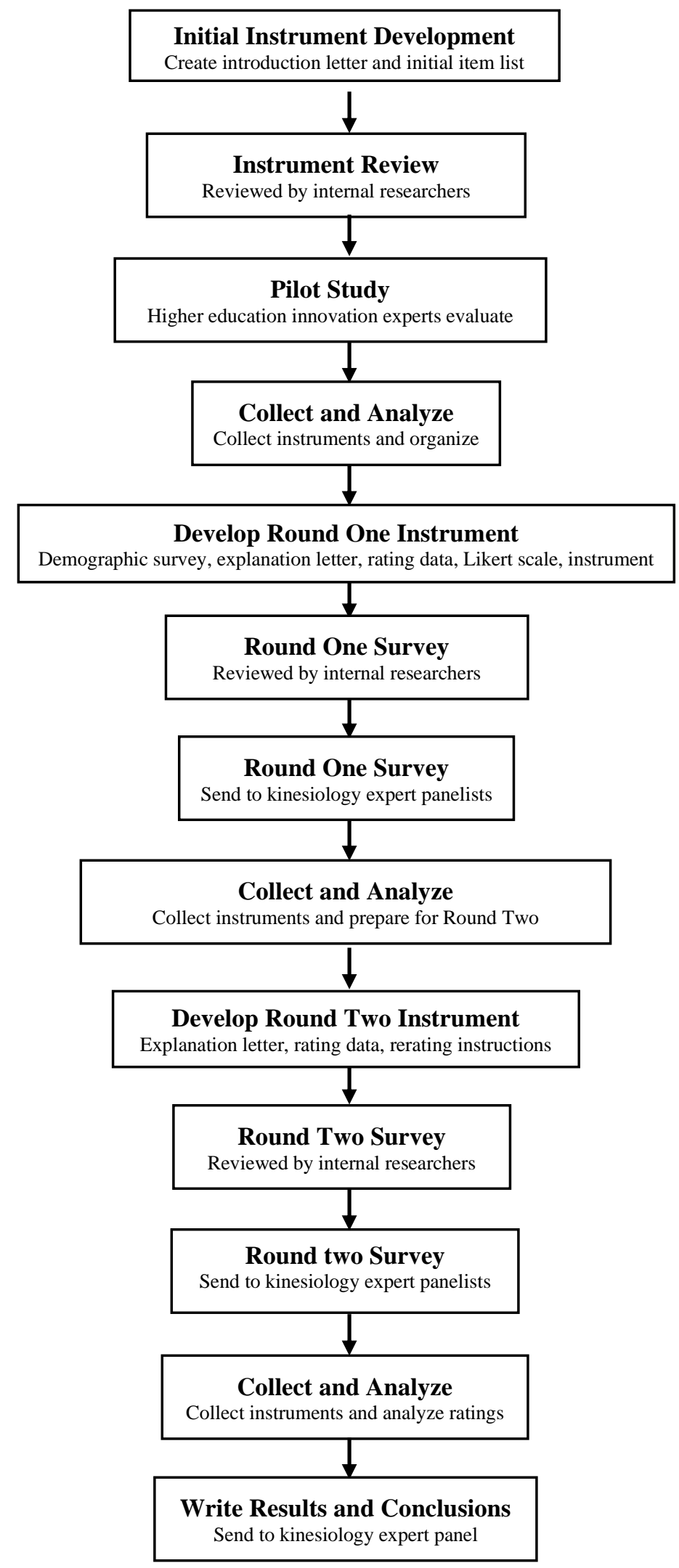




\section{Appendix D: Initial E-mail Request for Participation}

Dear Higher Education Kinesiology Leadership Expert,

This letter is to request your participation as an expert panel member for my dissertation research titled A Delphi Study Exploring the Impact and Feasibility of Entrepreneurial Initiatives in College/University Kinesiology Programs. This project is being conducted by Cory Breithoff, MS in the College of Physical Activity and Sports Sciences (CPASS) at WVU with supervision of Dr. Sean Bulger, a professor CPASS, for a PhD in Kinesiology. Your participation in this project is greatly appreciated and will take approximately 5 minutes to fill out the attached questionnaire.

Your involvement in this project will be kept as confidential as legally possible. All data will be reported in the aggregate. You must be 18 years of age or older to participate, as well as a current professional in a higher education kinesiology department. I will not ask any information that should lead back to your identity as a participant. Your participation is completely voluntary. You may skip any question that you do not wish to answer and you may discontinue at any time. You will not be affected if you decide either not to participate or to withdraw. There are no known benefits associated with participation in this study, but you will receive an executive summary of all results. West Virginia University's Institutional Review Board acknowledgement of this project is on file.

I hope that you will participate in this research project, as it could be beneficial in the impact and feasibility of entrepreneurship in kinesiology. Thank you very much for your time. Should you have any questions about this letter or the research project, please feel free to contact Cory Breithoff at (908) 310-9104 or by e-mail at cbreitho@ mix.wvu.edu or my supervisor at sean.bulger@mail.wvu.edu.

Please note by clicking on the provided link you are agreeing to participate in this study. Additional information on logistics of the study may be found in the attached advertisement. If possible, please return the completed survey to me within one week of receiving it. Thanks again for your assistance and cooperation.

\section{SURVEY LINK}

Thank you for your time and help with this project.

Sincerely,

Cory L. Breithoff, M.S.

West Virginia University

Morgantown, WV

(908) 310-9104

cbreitho@mix.wvu.edu
Sean M. Bulger

(304) 293-0845

sean.bulger@mail.wvu.edu 


\section{Appendix E: Recruitment Advertisement}

\section{Entrepreneurial Initiative in College/University Kinesiology Programs}

\section{Why is this research being conducted?}

The primary purpose of this research is to determine a list of highly impactful and feasible entrepreneurial initiatives that can be implemented in higher education kinesiology departments. The impetus for this research stems from the increasing demands in higher education and decreasing traditional revenue sources.

Upon completion, the expert panel has the opportunity to produce knowledge and guidance for college and university kinesiology departments who plan to implement new academic entrepreneurial initiatives. More importantly, the study is seeking to promote innovation through highly impactful and feasible ventures.

\section{How will this study be conducted?}

A two-round modified Delphi method using an online questionnaire will be used to generate strategies from the expert panel. For each round, the expert panel will answer a questionnaire. The first and second round will involve rating items via a Likert-scale. The second round will also have an open-ended question, asking participants to list facilitators and barriers to implementation of entrepreneurial initiatives.

\section{What are the criteria for participation?}

The Delphi panel will at least 20 participants who meet the following criteria:

- Current leader of a higher education kinesiology department that is a member department of the American Kinesiology Association.

- All participants must also be 18 years of age.

\section{What is your role if you choose to participate?}

Your participation in this research study is completely voluntary and you are free to withdraw from the research at any time. You may or may not directly benefit from participating in this research.

- Round One - Rate entrepreneurial initiatives in terms of their impact and feasibility of implementation in a higher education kinesiology setting.

- Round Two -Unlike the first round, the individual and group mean ratings for each initiative will be provided; thus, allowing you to see how your responses compare with the overall group (all names and individual ratings are anonymous). You will then be asked to re-evaluate your previous viewpoint/response in light of the overall group opinion and rate the initiatives a second time. Additionally, you will be asked to provide any facilitators or barriers to implementation of the provided initiatives.

You may or may not directly benefit from participating in this research.

\section{Time involved}

- Round one - Completion for this round is two weeks, spanning from March 18 - March 29. It is estimated that this round will take 10-15 minutes to complete. 
- Round two - Completion for this round is two weeks, spanning from April 1 - April 12. It is estimated that this round will take 10-15 minutes to complete.

Note: These times may be adjusted if all responses are received within the first week of a designated round.

Upon completion, an executive summary of the research will be sent to you.

\section{Questions for the researcher?}

If you have any questions or concerns about this research, you can contact Cory Breithoff, MS at insert (908) 310-9104 or cbreitho@mix.wvu.edu from the College of Physical Activity and Sports Sciences at West Virginia University. You may also contact my research supervisor Sean Bulger, Ed.D at sean.bulger@mail.wvu.edu.

*The West Virginia University Institution Review Board has acknowledgement of this research. 


\section{Appendix F: IRB Flex Consent Form}

\section{Entrepreneurial Initiative in College and University Kinesiology Programs}

\section{Why is this research being done and what is involved?}

The primary purpose of this study is to determine a list of highly impactful and feasible entrepreneurial initiatives that can be implemented in higher education kinesiology departments.

The impetus for this research stems from the increasing demands in higher education and decreasing traditional revenue sources. Upon completion, the expert panel has the opportunity to produce knowledge and guidance for college and university kinesiology departments who plan to implement new academic entrepreneurial initiatives. More importantly, the study is seeking to promote innovation through highly impactful and feasible ventures.

As a participant in this study, you will be asked to complete three surveys. The first is a brief demographic survey that verifies criteria for inclusion in this research. The second and third survey (round one and round two) will ask you to rate entrepreneurial initiatives in terms of their impact and feasibility of implementation in a higher education kinesiology setting using a provided 5-point Likert scale. In the third survey, you will also be requested to answer two open-ended questions regarding facilitators and barriers to implementation of the provided initiatives. Both the second and third surveys should take 15-20 minutes of your time. These surveys will all take place over a four week period and the research team is requesting you submit all responses within a week of receiving each survey.

Round one - Completion for this round is two weeks, spanning from March 18 - March 29. It is estimated that this round will take 10-15 minutes to complete.

Round two - Completion for this round is two weeks, spanning from April 1 - April 12. It is estimated that this round will take 10-15 minutes to complete.

\section{Do I have to participate and what are the risks?}

Your participation in this research study is completely voluntary and you are free to withdraw from the research at any time. You may or may not directly benefit from participating in this research.

It should be known that all participants will be required to be involved in the research process for up to four weeks.

\section{Who can I talk to if I have questions or concerns?}

You are free to stop participating in the research at any time

If you have any questions or concerns about this research, you can contact Cory Breithoff, MS at insert (908) 310-9104 or cbreitho@mix.wvu.edu from the College of Physical Activity and Sports Sciences at West Virginia University.

By completing the survey linked in this email, I willingly consent to participate in this research. 
The participant has had the opportunity to have questions addressed. The participant willingly agrees to be in the study. 


\section{Appendix G: Demographic Survey}

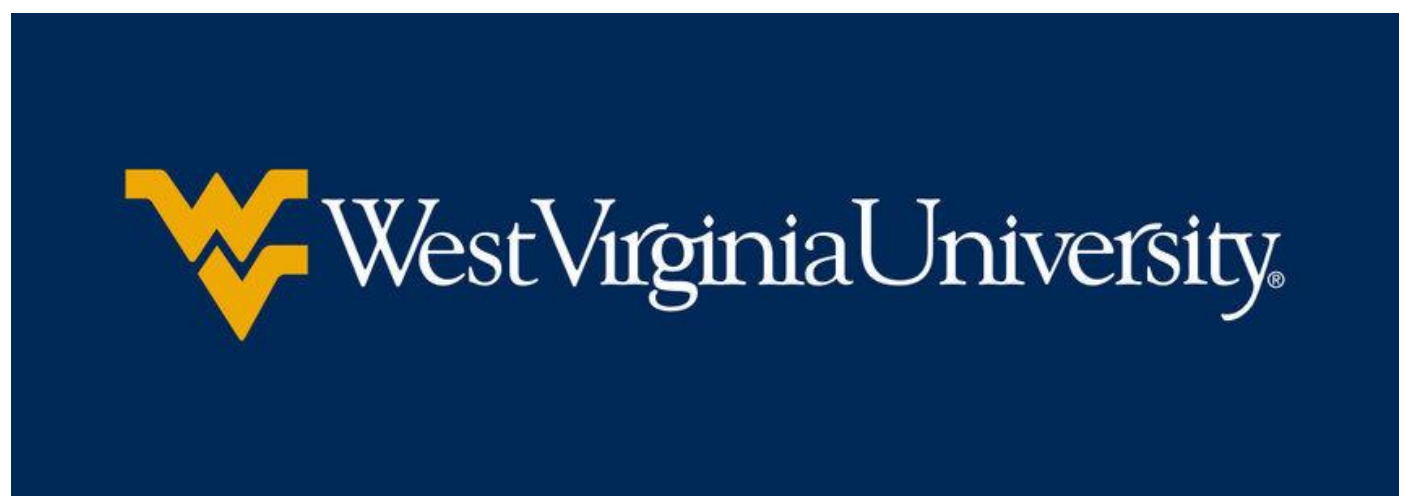

Thank you for choosing to participate in this study exploring entrepreneurial initiatives in higher education kinesiology. This demographic survey contains five questions and should only require less than five minutes to complete. You will be contacted via email within one week after completing this survey.

Additional Research Information Recruitment advertisement $\underline{\text { Consent Form }}$

\section{Page Break}

Contact information:

Name

Email Address

Phone Number 
Preferred Mode of Contact:

Email

Phone Call

Text Message

Please list the title of your leadership position.

Years in higher education:

$1-6$

$7-12$

$13-18$

$19-24$

$25-30$

$30+$

Based on the description of this research study, are there any additional kinesiology leaders you would recommend as panel members?

Individual 1

Individual 2

Individual 3 


\section{Appendix H: Round 1 Cover Letter}

\section{Dear Expert Panel Member,}

Thank you for agreeing to be a participant in my research titled A Delphi Study Exploring the Impact and Feasibility of Entrepreneurial Initiatives in College/University Kinesiology Programs. As described in the previous email, you were chosen because of your expertise in the area of higher education kinesiology leadership and innovation. This project is being conducted by Cory Breithoff, MS in the College of Physical Activity and Sports Sciences (CPASS) at WVU with supervision of Dr. Sean Bulger, a professor CPASS, for a $\mathrm{PhD}$ in Kinesiology. Your participation in this project is greatly appreciated and will take approximately 15 minutes to fill out the attached questionnaire.

The research will involve the use of a modified Delphi protocol to determine the impact and feasibility of entrepreneurial initiatives in higher education kinesiology departments. This investigative process will include two rounds of questionnaire circulation, which will take place over a four-week timeframe. The Delphi panel will consist of 30 kinesiology leaders who have been identified as experts in the area of innovation and leadership. As a panel member, you will be asked to rate a list of entrepreneurial initiatives regarding their impact and feasibility in higher education kinesiology departments.

Your involvement in this project will be kept as confidential as legally possible. All data will be reported in the aggregate. You must be 18 years of age or older to participate, as well as a current professional in a higher education kinesiology department. I will not ask any information that should lead back to your identity as a participant. Your participation is completely voluntary. You may skip any question that you do not wish to answer and you may discontinue at any time. You will not be affected if you decide either not to participate or to withdraw. There are no known benefits associated with participation in this study, but you will receive an executive summary of all results. West Virginia University's Institutional Review Board acknowledgement of this project is on file.

I hope that you will participate in this research project, as it could be beneficial in the impact and feasibility of entrepreneurship in kinesiology. Thank you very much for your time. Should you have any questions about this letter or the research project, please feel free to contact Cory Breithoff at (908) 310-9104 or by e-mail at cbreitho@ mix.wvu.edu or my supervisor at sean.bulger@mail.wvu.edu.

Please note by clicking on the provided link you are agreeing to participate in this study. If possible, please return the completed survey to me within one week of receiving it. Thanks again for your assistance and cooperation.

\section{SURVEY LINK}

Thank you for your time and help with this project. 
Sincerely,

Cory L. Breithoff, M.S.

West Virginia University

Morgantown, WV

(908) 310-9104

cbreitho@mix.wvu.edu

Sean M. Bulger

(304) 293-0845

sean.bulger@mail.wvu.edu 


\section{Appendix I: Round 1 Survey Instrument}

\section{Start of Block: Default Question Block}

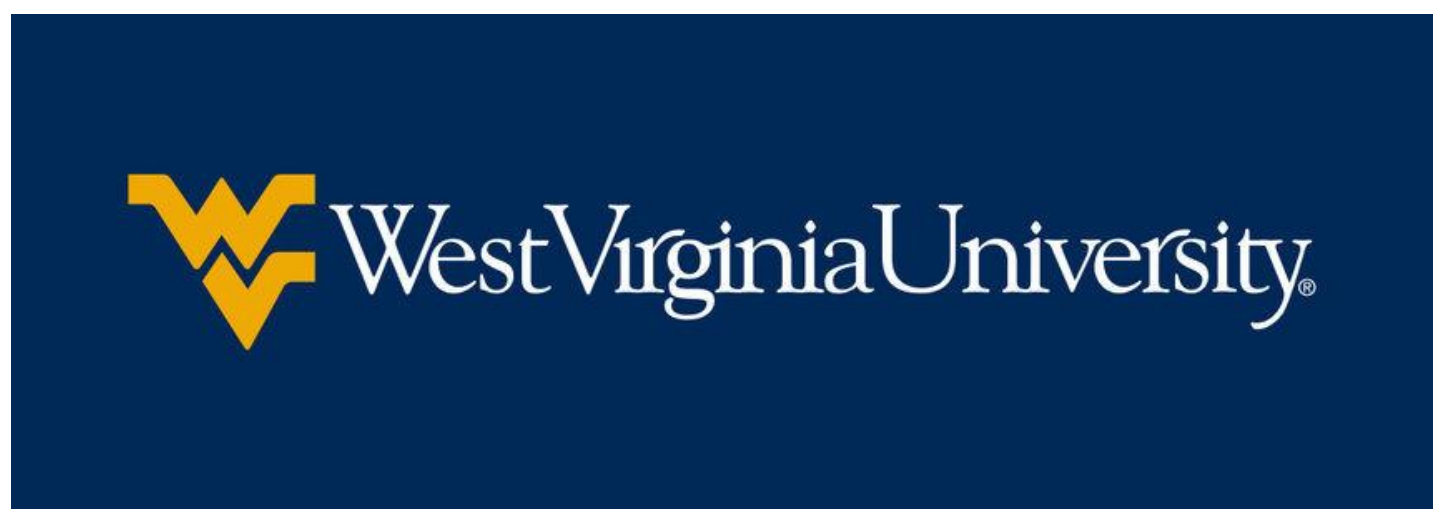

\section{Introduction}

The survey items you have agreed to review will be used during a subsequent research project to generate a consensus of expert opinion regarding the impact and feasibility of entrepreneurial initiatives in higher education kinesiology departments. The Delphi Method will be employed to address this primary research question. The Delphi Method is a research protocol that involves (a) the identification and selection of a small panel of experts on a particular topic, (b) the use of multiple rounds of surveying as a means to collect expert opinion, and (c) the attainment of group consensus through the provision of regular feedback.

Your expertise and judgment remain central to the success of this project because you are helping to identify the survey items that will eventually be considered by the actual Delphi panel members. Due to the nature of both the involved research question and the Delphi Method, the list of potential survey items I am asking you to evaluate is rather extensive. The items that you are evaluating were adapted were derived from a literature review and current entrepreneurial ventures in the field of kinesiology.

Please know that your commitment to the timely completion of this project is greatly appreciated.

Please download this PDF of item descriptions to assist you with any unclear terminology. Entrepreneurial Initiative Descriptions 
Please provide the following information.

(This is only for authentication purposes and will not be used as part of the research process).

Email Address

\section{Page Break}

Thank you for choosing to participate in this study exploring entrepreneurial initiatives in higher education kinesiology. This Round One survey contains 2 rating scales for each item and should take less than 20 minutes to complete.

- Rate each of the questionnaire items separately in the areas of IMPACT and

\section{FEASIBILITY.}

- For the purpose of this study, entrepreneurial initiative refers to an innovative or experimental new initiative that is intended to facilitate responsible change.

- Impact refers to the panel members' expected effect of an item as it relates to facilitating change.

- Feasibility refers to the state or degree of an item to be easily or conveniently implemented. A rating of (5) or (4) in BOTH IMPACT and FEASIBILITY means that you consider the item to be highly worthy of implementation in a higher education kinesiology department.

- A rating of (3) means you are neutral or undecided regarding the IMPACT and FEASIBILITY of the item.

$\bigcirc$ A rating of (2) or (1) on IMPACT or FEASIBILITY means the item may not be worthy of immediate implementation in a higher education kinesiology department.

- If you choose not to respond to a particular item, please leave it blank.

When all Round 1 surveys have been received and analyzed, I will email you the Round 2 instructions and questionnaire. The Round 2 questionnaire will include a summary of the responses from the Round 1 questionnaire for your further consideration. 


\begin{tabular}{|c|c|c|c|c|c|c|c|c|c|c|}
\hline \multicolumn{11}{|c|}{ Student Recruitment } \\
\hline & \multicolumn{5}{|c|}{ Impact } & \multicolumn{5}{|c|}{ Feasibility } \\
\hline & $\begin{array}{l}\text { Not at all } \\
\text { Impactful }\end{array}$ & $\begin{array}{l}\text { Slightly } \\
\text { Impactful }\end{array}$ & $\begin{array}{l}\text { Somewhat } \\
\text { Impactful }\end{array}$ & $\begin{array}{c}\text { Very } \\
\text { Impactful }\end{array}$ & $\begin{array}{l}\text { Extremely } \\
\text { Impactful }\end{array}$ & $\begin{array}{c}\text { Not at } \\
\text { all } \\
\text { Feasible }\end{array}$ & $\begin{array}{l}\text { Slightly } \\
\text { Feasible }\end{array}$ & $\begin{array}{l}\text { Somewhat } \\
\text { Feasible }\end{array}$ & $\begin{array}{l}\text { Very } \\
\text { Feasible }\end{array}$ & $\begin{array}{l}\text { Extremely } \\
\text { Feasible }\end{array}$ \\
\hline $\begin{array}{l}\text { Third-party recruiting } \\
\text { agents }\end{array}$ & O & $\mathrm{O}$ & O & O & O & O & O & O & O & O \\
\hline $\begin{array}{l}\text { Master's by } \\
\text { coursework (no } \\
\text { thesis based on } \\
\text { research study) }\end{array}$ & $\mathrm{O}$ & $\mathrm{O}$ & O & $\mathrm{O}$ & O & $\mathrm{O}$ & $\mathrm{O}$ & O & $\mathrm{O}$ & O \\
\hline $\begin{array}{l}\text { Expedited } \\
\text { admissions } \\
\text { decisions }\end{array}$ & $\mathrm{O}$ & $\mathrm{O}$ & O & $\mathrm{O}$ & O & $\mathrm{O}$ & $\mathrm{O}$ & O & $\mathrm{O}$ & O \\
\hline $\begin{array}{l}\text { Guided pathway } \\
\text { programs for } \\
\text { international } \\
\text { populations }\end{array}$ & $\mathrm{O}$ & $\mathrm{O}$ & O & $\mathrm{O}$ & O & $\mathrm{O}$ & $\mathrm{O}$ & O & $\mathrm{O}$ & O \\
\hline $\begin{array}{l}\text { Young professionals } \\
\text { condensed ESL } \\
\text { programs }\end{array}$ & $\mathrm{O}$ & $\mathrm{O}$ & O & $\mathrm{O}$ & $\mathrm{O}$ & $\mathrm{O}$ & $\mathrm{O}$ & O & $\mathrm{O}$ & O \\
\hline $\begin{array}{l}\text { Use of community } \\
\text { college recruiting } \\
\text { teams }\end{array}$ & $\mathrm{O}$ & $\mathrm{O}$ & O & O & O & $\mathrm{O}$ & $\mathrm{O}$ & O & $\mathrm{O}$ & O \\
\hline $\begin{array}{l}\text { Foreign-born faculty } \\
\text { student recruitment } \\
\text { trips }\end{array}$ & $\mathrm{O}$ & $\mathrm{O}$ & O & $\mathrm{O}$ & O & $\mathrm{O}$ & $\mathrm{O}$ & O & $\mathrm{O}$ & $\mathrm{O}$ \\
\hline $\begin{array}{l}\text { Customizable } \\
\text { degree programs }\end{array}$ & $\mathrm{O}$ & $\mathrm{O}$ & O & O & O & O & O & O & $\mathrm{O}$ & O \\
\hline $\begin{array}{l}\text { Enrollment/Retention } \\
\text { Coaching }\end{array}$ & $\mathrm{O}$ & $\mathrm{O}$ & O & $\mathrm{O}$ & O & $\mathrm{O}$ & O & O & $\mathrm{O}$ & O \\
\hline
\end{tabular}

Completeness: Please list any additional items you would recommend in the spaces provided.

Addition 1

Addition 2

Addition 3

Addition 4

Addition 5

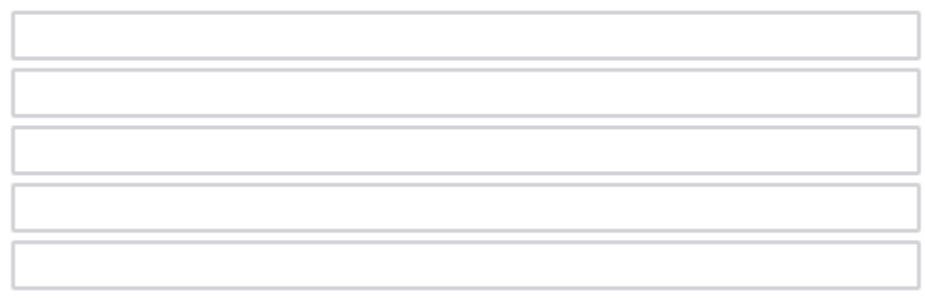




\section{Appendix J: Entrepreneurial Initiatives Descriptors PDF Attachment}

\section{Student Recruitment}

\begin{tabular}{|c|c|}
\hline \multicolumn{2}{|c|}{ Efforts made to recruit beyond the traditional avenues. } \\
\hline Third-party recruiting agents & $\begin{array}{l}\text { Agencies outside of the college or university hired specifically } \\
\text { for recruitment purposes. }\end{array}$ \\
\hline Master's by coursework & $\begin{array}{l}\text { Students earn a Masters degree through the completion of } \\
\text { established coursework only, no thesis is completed. }\end{array}$ \\
\hline $\begin{array}{l}\text { Expedited admissions } \\
\text { decisions }\end{array}$ & $\begin{array}{l}\text { Students receive near immediate admission decisions (could } \\
\text { be same day). }\end{array}$ \\
\hline $\begin{array}{l}\text { Guided pathway programs for } \\
\text { international populations }\end{array}$ & $\begin{array}{l}\text { Program intended to assist students with language proficiency } \\
\text { and familiarization of socio-cultural norms. }\end{array}$ \\
\hline $\begin{array}{l}\text { Young professionals } \\
\text { condensed ESL programs }\end{array}$ & $\begin{array}{l}\text { English as a second language programming that is specifically } \\
\text { designed for students taking college-level courses. }\end{array}$ \\
\hline $\begin{array}{l}\text { Use of community college } \\
\text { recruiting teams }\end{array}$ & Partnerships or pathways with community colleges. \\
\hline $\begin{array}{l}\text { Foreign-born faculty student } \\
\text { recruitment trips }\end{array}$ & $\begin{array}{l}\text { Foreign faculty return to home-country to recruit student } \\
\text { populations. }\end{array}$ \\
\hline Customizable degree programs & $\begin{array}{l}\text { Students have flexibility in program pathway and can pick } \\
\text { specific courses for program completion. }\end{array}$ \\
\hline Enrollment/Retention Coaching & $\begin{array}{l}\text { External or internal specialist tasked with providing } \\
\text { constant/consistent support from initial application through } \\
\text { graduation. }\end{array}$ \\
\hline $\begin{array}{l}\text { In-house recruiter/enrollment } \\
\text { specialist }\end{array}$ & $\begin{array}{l}\text { Professional from within department/school tasked with only } \\
\text { recruitment/enrollment responsibilities. }\end{array}$ \\
\hline $\begin{array}{l}\text { Consumer-targeted social } \\
\text { media recruitment strategies }\end{array}$ & $\begin{array}{l}\text { Recruitment materials designed specifically for college-aged } \\
\text { audience (peer designed using current modes of } \\
\text { communication, i.e. snapchat, virtual reality, etc.) }\end{array}$ \\
\hline Enhanced website content & $\begin{array}{l}\text { Websites with in-depth resources (included but not limited to } \\
\text { information about employability, salary, careers, etc.) that can } \\
\text { be navigated easily and on mobile devices. }\end{array}$ \\
\hline $\begin{array}{l}\text { Targeted video and digital } \\
\text { marketing campaigns }\end{array}$ & $\begin{array}{l}\text { Advertising designed for specific audiences and distributed } \\
\text { accordingly. }\end{array}$ \\
\hline
\end{tabular}




\begin{tabular}{|c|l|}
\hline $\begin{array}{c}\text { Intentional lead generation } \\
\text { efforts }\end{array}$ & $\begin{array}{l}\text { Purposefully collated potential consumer information used } \\
\text { specifically for recruitment and enrollment. }\end{array}$ \\
\hline $\begin{array}{c}\text { Explicit career pathways and } \\
\text { experiential learning } \\
\text { opportunities }\end{array}$ & $\begin{array}{l}\text { Advertised career pathways and experiential learning } \\
\text { opportunities, these may align or begin in secondary schools. }\end{array}$ \\
\hline Unique scholarship strategies & Legacy programs, dual-degrees, etc. \\
\hline $\begin{array}{c}\text { Current student and recent } \\
\text { graduate referral programs }\end{array}$ & $\begin{array}{l}\text { Using the populations listed to aid with recruitment; benefits } \\
\text { may be provided for enticement of efforts. }\end{array}$ \\
\hline
\end{tabular}

\section{Summer and Intersession Blended Learning}

\begin{tabular}{|c|c|}
\hline \multicolumn{2}{|c|}{ Learning opportunities that take place outside of the traditional school calendar/semesters. } \\
\hline $\begin{array}{l}\text { Extended stay summer } \\
\text { term }\end{array}$ & $\begin{array}{l}\text { Students continue to stay on campus for coursework beyond the } \\
\text { end of spring semester (may continue course already in progress or } \\
\text { enroll in additional coursework). }\end{array}$ \\
\hline $\begin{array}{l}\text { Oversubscribed course } \\
\text { summer sessions }\end{array}$ & $\begin{array}{l}\text { Courses that are often difficult to register in during fall/spring are } \\
\text { offered in high numbers during summer to accommodate demand. }\end{array}$ \\
\hline $\begin{array}{l}\text { High-demand major } \\
\text { prerequisite summer } \\
\text { sessions }\end{array}$ & $\begin{array}{l}\text { Prerequisite coursework that is in high-demand is offered during the } \\
\text { summer session (only or additionally). }\end{array}$ \\
\hline $\begin{array}{l}\text { Independent study summer } \\
\text { sessions }\end{array}$ & $\begin{array}{l}\text { Students have the flexibility to learn content through independent } \\
\text { studies (could be used as a substitute for required coursework or } \\
\text { an elective). }\end{array}$ \\
\hline $\begin{array}{l}\text { Open enrollment } \\
\text { intersession courses }\end{array}$ & $\begin{array}{l}\text { Students may enroll at any point in time, rather than follow } \\
\text { traditional acceptance timelines. }\end{array}$ \\
\hline $\begin{array}{l}\text { Summer and intersession } \\
\text { financial aid }\end{array}$ & $\begin{array}{l}\text { Monetary support to aid students with the costs of higher education } \\
\text { coursework. }\end{array}$ \\
\hline $\begin{array}{l}\text { General education } \\
\text { requirement blended } \\
\text { courses }\end{array}$ & $\begin{array}{l}\text { Courses that fulfill general education requirements through both } \\
\text { online and face-to-face formats, allowing for more flexibility in } \\
\text { learners location. }\end{array}$ \\
\hline
\end{tabular}




\begin{tabular}{|c|l|}
\hline $\begin{array}{c}\text { Study abroad makeup } \\
\text { courses }\end{array}$ & $\begin{array}{l}\text { Students may take courses that are missed in a program or study } \\
\text { or failed while completing a study abroad experience. }\end{array}$ \\
\hline $\begin{array}{c}\text { Experiential learning } \\
\text { opportunities }\end{array}$ & $\begin{array}{l}\text { Experiences outside a traditional academic setting that enable } \\
\text { students to develop knowledge, skills, and values. }\end{array}$ \\
\hline $\begin{array}{c}\text { Co-ops/internship } \\
\text { placements }\end{array}$ & $\begin{array}{l}\text { Work placements (may be paid) that occur throughout the } \\
\text { traditional plan of study and count for academic credit. }\end{array}$ \\
\hline $\begin{array}{c}\text { Specialized events for } \\
\text { current students/alumni }\end{array}$ & $\begin{array}{l}\text { College/University organized events centered around networking, } \\
\text { recruitment visits, and targeted list-purchases. }\end{array}$ \\
\hline
\end{tabular}

\section{Distance Learning Articulation Agreements}

\begin{tabular}{|c|c|}
\hline \multicolumn{2}{|c|}{ Agreements established to benefit distance learners. } \\
\hline $\begin{array}{l}\text { Out of state community college } \\
\text { online programs }\end{array}$ & $\begin{array}{l}\text { Students may take community college courses online and } \\
\text { receive in-state advantages (ie. tuition costs). }\end{array}$ \\
\hline Blended courses/programs & $\begin{array}{l}\text { Coursework or entire programs completed both online and } \\
\text { face-to-face. }\end{array}$ \\
\hline $\begin{array}{l}\text { Online dual enrollment } \\
\text { programs }\end{array}$ & $\begin{array}{l}\text { Enrolling students who may be studying at another institution } \\
\text { (this may be higher education or K12). }\end{array}$ \\
\hline $\begin{array}{l}\text { Dual-degree programs with } \\
\text { other universities }\end{array}$ & $\begin{array}{l}\text { Working to earn degrees simultaneously from more than one } \\
\text { university or possibly working to complete one degree from } \\
\text { more than one partnering institution. }\end{array}$ \\
\hline $\begin{array}{l}\text { Articulations with private } \\
\text { companies/organizations }\end{array}$ & $\begin{array}{l}\text { Agreements with private companies/organizations to offer } \\
\text { educational credits or coursework. }\end{array}$ \\
\hline $\begin{array}{l}\text { International institution graduate } \\
\text { partnership agreements }\end{array}$ & $\begin{array}{l}\text { Institutions that partner with academic institutions across the } \\
\text { globe to expand curricular offerings, research collaborations, } \\
\text { and intercultural opportunities for mobility of graduate } \\
\text { students. }\end{array}$ \\
\hline International partnerships & Partnerships with particular countries. \\
\hline $\begin{array}{l}\text { Online employment skills } \\
\text { certificate programs }\end{array}$ & $\begin{array}{l}\text { Programs designed to teach employable skills/knowledge that } \\
\text { cannot be automated. }\end{array}$ \\
\hline
\end{tabular}




\section{Distance Learning Course Licensing}

\begin{tabular}{|c|l|}
\hline \multicolumn{2}{|c|}{ Faculty or higher education professionals develop materials that can be distributed for profit. } \\
\hline $\begin{array}{c}\text { Recreational learning } \\
\text { brand licensing }\end{array}$ & $\begin{array}{l}\text { Creation of a learning brand that can be owned and used to create } \\
\text { products under one name. }\end{array}$ \\
\hline $\begin{array}{c}\text { Turnkey homeschool } \\
\text { curriculum }\end{array}$ & $\begin{array}{l}\text { Homeschool curriculum that can be sold and used with no prior } \\
\text { knowledge or education on the subject matter. }\end{array}$ \\
\hline $\begin{array}{c}\text { Capstone case study } \\
\text { sales }\end{array}$ & $\begin{array}{l}\text { Capstone experiences that are designed to be recreated by the } \\
\text { masses. }\end{array}$ \\
\hline $\begin{array}{c}\text { International course sales } \\
\text { translated by consumer) }\end{array}$ \\
\hline
\end{tabular}

\section{Applied and Professional Masters}

\begin{tabular}{|c|c|}
\hline \multicolumn{2}{|c|}{ Non-traditional students are able to earn a Masters degree through non-traditional means. } \\
\hline $\begin{array}{l}\text { On-demand new cohort } \\
\text { programs }\end{array}$ & $\begin{array}{l}\text { Programs are started based on consumer demand (created or start } \\
\text { date). }\end{array}$ \\
\hline $\begin{array}{l}\text { Professional science } \\
\text { Masters }\end{array}$ & $\begin{array}{l}\text { Designed in partnership with employers and feature learning in } \\
\text { real-world environments. }\end{array}$ \\
\hline $\begin{array}{l}\text { Interdisciplinary terminal } \\
\text { Masters }\end{array}$ & $\begin{array}{l}\text { Creation of a terminal Masters (no higher degree in that area) that } \\
\text { covers multiple fields of knowledge. }\end{array}$ \\
\hline Weekend course Masters & $\begin{array}{l}\text { Masters is earned through the completion of intensive weekend- } \\
\text { long or weekend-driven coursework. }\end{array}$ \\
\hline Applied liberal arts Masters & $\begin{array}{l}\text { Students earn a degree in a wide range of transferable skills and } \\
\text { knowledge, rather than one content area/field. }\end{array}$ \\
\hline Stackable certificates & $\begin{array}{l}\text { Students create a sequence of credentials over time to build up } \\
\text { their qualifications. }\end{array}$ \\
\hline $\begin{array}{l}\text { New regulatory requirement } \\
\text { certificates }\end{array}$ & $\begin{array}{l}\text { Certificates offered to meet the demands of the marketplace and } \\
\text { regulatory requirements. }\end{array}$ \\
\hline $\begin{array}{l}\text { Accelerated degree } \\
\text { programs }\end{array}$ & $\begin{array}{l}\text { Students are able to overlap their degree work and complete an } \\
\text { advanced curriculum to earn multiple degrees in a shorter } \\
\text { timeframe (i.e. 3-yr BS; BS-MS; etc.) }\end{array}$ \\
\hline
\end{tabular}




\begin{tabular}{|c|l|}
\hline $\begin{array}{c}\text { Microcredentialing and } \\
\text { nanodegrees }\end{array}$ & $\begin{array}{l}\text { The repackaging of selected content for a targeted purpose (and } \\
\text { for individuals in possession of bachelor's degrees that have not } \\
\text { provided "pathways to top jobs"). }\end{array}$ \\
\hline Digital Badging & $\begin{array}{l}\text { A validated indicator of accomplishment, skill, quality, or interest } \\
\text { that can be earned in many learning environments. }\end{array}$ \\
\hline Employee-based cohorts & $\begin{array}{l}\text { Cohorts created and enrolled only with employees of particular } \\
\text { companies. }\end{array}$ \\
\hline $\begin{array}{c}\text { Discounted pricing for } \\
\text { professional-based cohorts }\end{array}$ & $\begin{array}{l}\text { Cheaper fees or tuition for cohorts enrolled with working } \\
\text { professionals. }\end{array}$ \\
\hline Flexible term start & $\begin{array}{l}\text { Students can enroll in programs at different parts of the academic } \\
\text { year (spring, summer, or fall). Students may also be able to enroll } \\
\text { at different intervals throughout a particular semester. }\end{array}$ \\
\hline Fully online lifetime portfolio & $\begin{array}{l}\text { Learning portfolios that can follow a student throughout multiple } \\
\text { degrees (BS, MS, EDD, CPD). }\end{array}$ \\
\hline
\end{tabular}

\section{Customized Corporate Training and Partnerships}

\begin{tabular}{|c|l|}
\hline \multicolumn{2}{|c|}{ Higher education institutions work with corporations to create and/or administer training. } \\
\hline Career path maps & $\begin{array}{l}\text { The development of career paths or career ladders that can be } \\
\text { used by a corporation for its employees to follow. }\end{array}$ \\
\hline $\begin{array}{c}\text { Online professional } \\
\text { Masters }\end{array}$ & $\begin{array}{l}\text { A professional masters that can be achieved through solely online } \\
\text { coursework. }\end{array}$ \\
\hline $\begin{array}{c}\text { After-hours course } \\
\text { scheduling }\end{array}$ & Course scheduling that meets the demands of full-time employees. \\
\hline $\begin{array}{c}\text { Rapid-cycle customized } \\
\text { curriculum offerings }\end{array}$ & $\begin{array}{l}\text { A curriculum that is developed with flexibility in mind. May change } \\
\text { to meet consumer demand at any point. }\end{array}$ \\
\hline $\begin{array}{c}\text { Templatized company } \\
\text { policies }\end{array}$ & $\begin{array}{l}\text { Universities/colleges would take part in developing templates that } \\
\text { can be used by corporations to help educate employees on policies } \\
\text { and other pertinent information. }\end{array}$ \\
\hline $\begin{array}{c}\text { Corporate advisory } \\
\text { committees }\end{array}$ & $\begin{array}{l}\text { Committees that are used to advise corporations on education } \\
\text { elements related to their businesses. }\end{array}$ \\
\hline $\begin{array}{c}\text { Referral programs of } \\
\text { potential employers }\end{array}$ & $\begin{array}{l}\text { Programs that connect potential employers directly to graduates of } \\
\text { degree programs. }\end{array}$ \\
\hline
\end{tabular}




\begin{tabular}{|c|l|}
\hline $\begin{array}{c}\text { Partnerships with non- } \\
\text { profits and professional } \\
\text { associations }\end{array}$ & $\begin{array}{l}\text { Institution partnerships with non-profits or professional associations } \\
\text { that have a shared purpose or field. }\end{array}$ \\
\hline $\begin{array}{c}\text { Corporate initiatives for } \\
\text { underserved }\end{array}$ & $\begin{array}{l}\text { Partnerships with colleges/universities and corporations that seek } \\
\text { to develop initiatives to identify and serve underserved populations. }\end{array}$ \\
\hline $\begin{array}{c}\text { Continuing professional } \\
\text { development for } \\
\text { corporations }\end{array}$ & $\begin{array}{l}\text { Offering coursework and learning opportunities directly related to } \\
\text { the needs of continued professional development. }\end{array}$ \\
\hline $\begin{array}{c}\text { Tuition breaks for } \\
\text { partnering companies }\end{array}$ & $\begin{array}{l}\text { Discounted tuition or agreements designed specifically for partner } \\
\text { companies. }\end{array}$ \\
\hline $\begin{array}{c}\text { Recognition of company } \\
\text { training as degree pursuant }\end{array}$ & $\begin{array}{l}\text { Company training that can be applied to degree programs as credit } \\
\text { worthy coursework. }\end{array}$ \\
\hline
\end{tabular}

\section{Seniors' Enrichment Programs}

\begin{tabular}{|c|l|}
\hline \multicolumn{2}{|c|}{ Programs that are aimed at lifelong learning experiences and senior populations. } \\
\hline Couples' memberships & Students who enroll as partners are able to receive perks. \\
\hline Expanded course audit catalogs & The courses that a student can audit are greatly expanded. \\
\hline $\begin{array}{c}\text { Priced-to-market course audit } \\
\text { Local excursion weekends }\end{array}$ & $\begin{array}{l}\text { Courses are priced based on the demand for the product. } \\
\text { the university/college. }\end{array}$ \\
\hline Faculty-led destination travel & $\begin{array}{l}\text { Faculty lead destination trips that can be taken by senior students } \\
\text { and have an educational component. }\end{array}$ \\
\hline Osher lifelong learning grants & $\begin{array}{l}\text { Osher grants that are established specifically for mature } \\
\text { populations. }\end{array}$ \\
\hline College-affiliated retirement \\
communities
\end{tabular}




\begin{tabular}{|c|l|}
\hline $\begin{array}{c}\text { Sport and eco-tourism } \\
\text { approaches }\end{array}$ & $\begin{array}{l}\text { College/university tours or trips that are related to sport and eco- } \\
\text { tourism. }\end{array}$ \\
\hline $\begin{array}{c}\text { Faculty-led inter-generational } \\
\text { study abroad trips }\end{array}$ & $\begin{array}{l}\text { Study abroad trips that cater to several generations, led } \\
\text { specifically by faculty. }\end{array}$ \\
\hline Enrichment courses & $\begin{array}{l}\text { Courses that are used as continued learning to enrich senior } \\
\text { knowledge in specific content areas. }\end{array}$ \\
\hline Themed yearly lecture series & $\begin{array}{l}\text { College/university sponsored lectures that are open or marketed to } \\
\text { senior age learners. }\end{array}$ \\
\hline
\end{tabular}

\section{Testing and Certification}

\begin{tabular}{|c|c|}
\hline \multicolumn{2}{|c|}{ Any testing or certification materials that are created or marketed by a higher education institution. } \\
\hline $\begin{array}{l}\text { Professional society testing } \\
\text { partnerships }\end{array}$ & $\begin{array}{l}\text { Partnerships with any professional community with the objective to } \\
\text { create testing materials. }\end{array}$ \\
\hline ESL testing and certification & Creation or distribution of ESL testing or certification materials. \\
\hline $\begin{array}{l}\text { Distance learning proctoring } \\
\text { services }\end{array}$ & $\begin{array}{l}\text { Universities serve as a site to proctor examines in a controlled setting } \\
\text { for distance learners. }\end{array}$ \\
\hline Placement test fees & Earnings that are related to placement tests. \\
\hline $\begin{array}{l}\text { For-profit educator testing } \\
\text { site rental }\end{array}$ & $\begin{array}{l}\text { Universities serve as a site for students to complete elements of } \\
\text { programs that need to be taken in face-to-face format. }\end{array}$ \\
\hline Online remedial programs & $\begin{array}{l}\text { Universities and colleges create remedial programs that can be taken } \\
\text { to aid students in common issue areas. }\end{array}$ \\
\hline $\begin{array}{l}\text { Coaching certification } \\
\text { programs }\end{array}$ & Institutions create certification programs for coaching. \\
\hline $\begin{array}{l}\text { Building testing and testing } \\
\text { prep into the curriculum }\end{array}$ & $\begin{array}{l}\text { Colleges build mandated/regulated testing and preparation into the } \\
\text { curriculum so it can be paid for with financial aid funds and not out of } \\
\text { pocket. }\end{array}$ \\
\hline $\begin{array}{l}\text { Diagnostic testing in clinical } \\
\text { settings }\end{array}$ & $\begin{array}{l}\text { Medical testing that can be offered through clinical settings, benefitting } \\
\text { the learner and the consumer. }\end{array}$ \\
\hline
\end{tabular}




\section{Faculty Consulting}

\begin{tabular}{|c|l|}
\hline \multicolumn{2}{|c|}{ Faculty uses their knowledge and expertise in the role of a consultant. } \\
\hline $\begin{array}{c}\text { International university } \\
\text { curriculum consulting }\end{array}$ & $\begin{array}{l}\text { Faculty consults on the creation of an international university } \\
\text { curriculum. }\end{array}$ \\
\hline Faculty expertise databases & $\begin{array}{l}\text { Faculty creates databases driven by their expertise that can aid } \\
\text { outside communities. }\end{array}$ \\
\hline $\begin{array}{c}\text { Industry sponsored capstone } \\
\text { projects }\end{array}$ & $\begin{array}{l}\text { Faculty consults on the creation of industry-driven capstone } \\
\text { projects. }\end{array}$ \\
\hline Nurse practitioner practices & Faculty consults on practitioner practices. \\
\hline Personal training & The faculty is consultants in a personal training context. \\
\hline Therapy sessions & $\begin{array}{l}\text { Faculty provides therapy (physical, emotional, mental) based on } \\
\text { expertise (maybe through a clinic). }\end{array}$ \\
\hline
\end{tabular}

\section{Community Partnerships}

\begin{tabular}{|c|l|}
\hline \multicolumn{2}{|c|}{ Universities/colleges establish partnerships with local communities. } \\
\hline Summer youth camps & $\begin{array}{l}\text { Universities/colleges create and facilitate summer youth } \\
\text { camps related to content or activities held on campus. }\end{array}$ \\
\hline Community activity programs & $\begin{array}{l}\text { Universities/colleges create and facilitate community } \\
\text { activity programs related to content or activities held on } \\
\text { campus. }\end{array}$ \\
\hline Community lectures & $\begin{array}{l}\text { Universities/colleges provide the community with lectures } \\
\text { by faculty or staff members. }\end{array}$ \\
\hline $\begin{array}{c}\text { Multi-generational activity opportunities } \\
\text { Community/professional associations } \\
\text { sponsored presentations/outreach }\end{array}$ & $\begin{array}{l}\text { Classes or activities that cater to multiple generations at } \\
\text { the same time. }\end{array}$ \\
\hline $\begin{array}{c}\text { Under-served populations } \\
\text { conducted by college/university faculty or staff. }\end{array}$ & $\begin{array}{l}\text { Programs designed to focus on underserved populations } \\
\text { or incentives that drive this consumer base in. }\end{array}$ \\
\hline $\begin{array}{c}\text { Public school career academy } \\
\text { partnerships }\end{array}$ & $\begin{array}{l}\text { Partnerships created between post-secondary institutions } \\
\text { and secondary career academies to help create pathways } \\
\text { to learning. }\end{array}$ \\
\hline
\end{tabular}




\section{Appendix K: Round 2 Cover Letter}

\section{Dear Expert Panel Member,}

Thank you for continuing to be a participant in my research titled A Delphi Study Exploring the Impact and Feasibility of Entrepreneurial Initiatives in College/University Kinesiology Programs. In this round, your task will be to rate each item in the questionnaire for a second time. Additionally, you will find the group mean ratings and your previous ratings in an attachment to this email. Please note that these should be used when considering your ratings throughout this round. This project is being conducted by Cory Breithoff, MS in the College of Physical Activity and Sports Sciences (CPASS) at WVU with supervision of Dr. Sean Bulger, a professor CPASS, for a PhD in Kinesiology. Your participation in this project is greatly appreciated and will take approximately 20 minutes to fill out the attached questionnaire.

All items you are evaluating are the same as Round one, with the exception of any additions from the panel members. Please read the instructions that have been provided before completing the survey. If you have any questions, contact me at (908) 310-9104 or cbreitho@ mix.wvu.edu.

Your involvement in this project will be kept as confidential as legally possible. All data will be reported in the aggregate. You must be 18 years of age or older to participate, as well as a current professional in a higher education kinesiology department. I will not ask any information that should lead back to your identity as a participant. Your completion of this second-round questionnaire is essential for the continued success of this study. While it is critical that you complete this second and final round of the rating process, your participation is completely voluntary. You may skip any question that you do not wish to answer and you may discontinue at any time. You will not be affected if you decide either not to participate or to withdraw. There are no known benefits associated with participation in this study, but you will receive an executive summary of all results. West Virginia University's Institutional Review Board acknowledgement of this project is on file.

I hope that you will participate in this research project, as it could be beneficial in the impact and feasibility of entrepreneurship in kinesiology. Thank you very much for your time. Should you have any questions about this letter or the research project, please feel free to contact Cory Breithoff at (908) 310-9104 or by e-mail at cbreitho@ mix.wvu.edu or my supervisor at sean.bulger@mail.wvu.edu.

Please note by clicking on the provided link you are agreeing to participate in this study. If possible, please return the completed survey to me within one week of receiving it. Thanks again for your assistance and cooperation.

\section{SURVEY LINK}

Thank you for your time and help with this project. 
Sincerely,

Cory L. Breithoff, M.S.

Sean M. Bulger

West Virginia University

(304) 293-0845

Morgantown, WV

sean.bulger@mail.wvu.edu

(908) 310-9104

cbreitho@mix.wvu.edu 


\section{Appendix L: Round 2 Survey Instrument}

\section{Start of Block: Default Question Block}

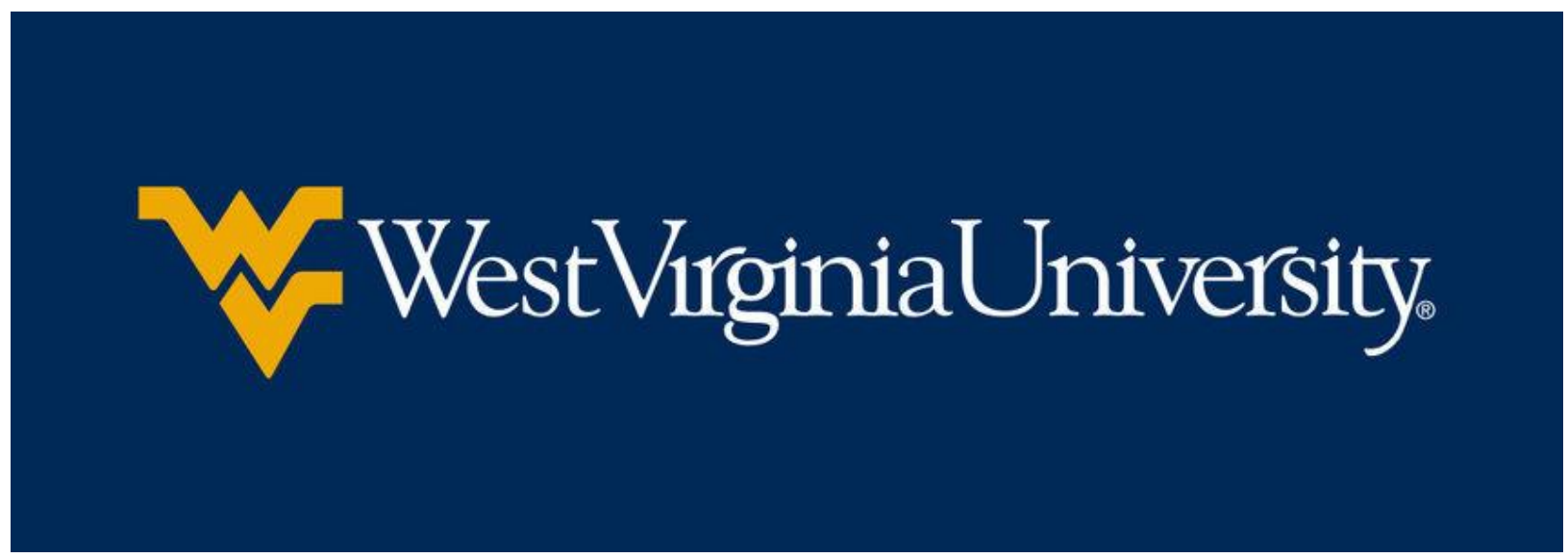

\section{Introduction}

The survey items you have agreed to review will be used during a subsequent research project to generate a consensus of expert opinion regarding the impact and feasibility of entrepreneurial initiatives in higher education kinesiology departments. The Delphi Method will be employed to address this primary research question. The Delphi Method is a research protocol that involves (a) the identification and selection of a small panel of experts on a particular topic, (b) the use of multiple rounds of surveying as a means to collect expert opinion, and (c) the attainment of group consensus through the provision of regular feedback.

Your expertise and judgment remain central to the success of this project because you are helping to identify the survey items that will eventually be considered by the actual Delphi panel members. Due to the nature of both the involved research question and the Delphi Method, the list of potential survey items I am asking you to evaluate is rather extensive. The items that you are evaluating were adapted were derived from a literature review and current entrepreneurial ventures in the field of kinesiology.

Please know that your commitment to the timely completion of this project is greatly appreciated. 
Please provide the following information.

(This is only for authentication purposes and will not be used as part of the research process).

Email Address

\section{Page Break}

Thank you for choosing to participate in this study exploring entrepreneurial initiatives in higher education kinesiology. This Round Two survey contains 2 rating scales for each item and two open-ended questions. The survey should take less than 20 minutes to complete.

\section{Please refer to the provided ratings from Round One while rating items during this round.}

- Rate each of the questionnaire items separately in the areas of IMPACT and FEASIBILITY. For the purpose of this study, entrepreneurial initiative refers to an innovative or experimental new initiative that is intended to facilitate responsible change. Impact refers to the panel members' expected effect of an item as it relates to facilitating change. Feasibility refers to the state or degree of an item to be easily or conveniently implemented.

- A rating of (5) or (4) in BOTH IMPACT and FEASIBILITY means that you consider the item to be highly worthy of implementation in a higher education kinesiology department.

- A rating of (3) means you are neutral or undecided regarding the IMPACT and FEASIBILITY of the item.

- A rating of (2) or (1) on IMPACT or FEASIBILITY means the item may not be worthy of immediate implementation in a higher education kinesiology department.

- If you choose not to respond to a particular item, please leave it blank.

Once all surveys have been collected and analyzed, you will receive an executive summary of the results. 


\begin{tabular}{|c|c|c|c|c|c|c|c|c|c|c|}
\hline \multicolumn{11}{|c|}{ Student Recruitment } \\
\hline & \multicolumn{5}{|c|}{ Impact } & \multicolumn{5}{|c|}{ Feasibility } \\
\hline & $\begin{array}{l}\text { Not at all } \\
\text { Impactful }\end{array}$ & $\begin{array}{l}\text { Slightly } \\
\text { Impactful }\end{array}$ & $\begin{array}{l}\text { Somewhat } \\
\text { Impactful }\end{array}$ & $\begin{array}{l}\text { Very } \\
\text { Impactful }\end{array}$ & $\begin{array}{l}\text { Extremely } \\
\text { Impactful }\end{array}$ & $\begin{array}{l}\text { Not at } \\
\text { all } \\
\text { Feasible }\end{array}$ & $\begin{array}{l}\text { Slightly } \\
\text { Feasible }\end{array}$ & $\begin{array}{l}\text { Somewhat } \\
\text { Feasible }\end{array}$ & $\begin{array}{l}\text { Very } \\
\text { Feasible }\end{array}$ & $\begin{array}{l}\text { Extremely } \\
\text { Feasible }\end{array}$ \\
\hline $\begin{array}{l}\text { Third-party recruiting } \\
\text { agents }\end{array}$ & $\mathrm{O}$ & $\mathrm{O}$ & O & $\mathrm{O}$ & O & $\mathrm{O}$ & $\mathrm{O}$ & O & $\mathrm{O}$ & O \\
\hline $\begin{array}{l}\text { Master's by } \\
\text { coursework (no } \\
\text { thesis based on } \\
\text { research study) }\end{array}$ & $\mathrm{O}$ & $\mathrm{O}$ & O & $\mathrm{O}$ & $\mathrm{O}$ & $\mathrm{O}$ & $\mathrm{O}$ & $\mathrm{O}$ & $\mathrm{O}$ & O \\
\hline $\begin{array}{l}\text { Expedited } \\
\text { admissions } \\
\text { decisions }\end{array}$ & $\mathrm{O}$ & $\mathrm{O}$ & O & $\mathrm{O}$ & $\mathrm{O}$ & $\mathrm{O}$ & $\mathrm{O}$ & $\mathrm{O}$ & $\mathrm{O}$ & ○ \\
\hline $\begin{array}{l}\text { Guided pathway } \\
\text { programs for } \\
\text { international } \\
\text { populations }\end{array}$ & $\mathrm{O}$ & $\mathrm{O}$ & O & $\mathrm{O}$ & ○ & $\mathrm{O}$ & $\mathrm{O}$ & $\mathrm{O}$ & $\mathrm{O}$ & ○ \\
\hline $\begin{array}{l}\text { Young professionals } \\
\text { condensed ESL } \\
\text { programs }\end{array}$ & $\mathrm{O}$ & $\mathrm{O}$ & O & $\mathrm{O}$ & O & $\mathrm{O}$ & $\mathrm{O}$ & $\mathrm{O}$ & $\mathrm{O}$ & ○ \\
\hline $\begin{array}{l}\text { Use of community } \\
\text { college recruiting } \\
\text { teams }\end{array}$ & $\mathrm{O}$ & $\mathrm{O}$ & O & $\mathrm{O}$ & O & $\mathrm{O}$ & $\mathrm{O}$ & $\mathrm{O}$ & $\mathrm{O}$ & ○ \\
\hline $\begin{array}{l}\text { Foreign-born faculty } \\
\text { student recruitment } \\
\text { trips }\end{array}$ & $\mathrm{O}$ & $\mathrm{O}$ & $\mathrm{O}$ & $\mathrm{O}$ & ○ & $\mathrm{O}$ & $\mathrm{O}$ & $\mathrm{O}$ & $\mathrm{O}$ & ○ \\
\hline $\begin{array}{l}\text { Customizable } \\
\text { degree programs }\end{array}$ & $\mathrm{O}$ & O & O & $\mathrm{O}$ & O & $\mathrm{O}$ & $\mathrm{O}$ & O & O & O \\
\hline $\begin{array}{l}\text { Enrollment/Retention } \\
\text { Coaching }\end{array}$ & $\mathrm{O}$ & O & O & $\mathrm{O}$ & ○ & $\mathrm{O}$ & O & O & O & ○ \\
\hline
\end{tabular}


Completeness: Please list any facilitators to implementation of entrepreneurial initiatives that you believe are noteworthy.

Facilitator 1

Facilitator 2

Facilitator 3

Facilitator 4

Facilitator 5

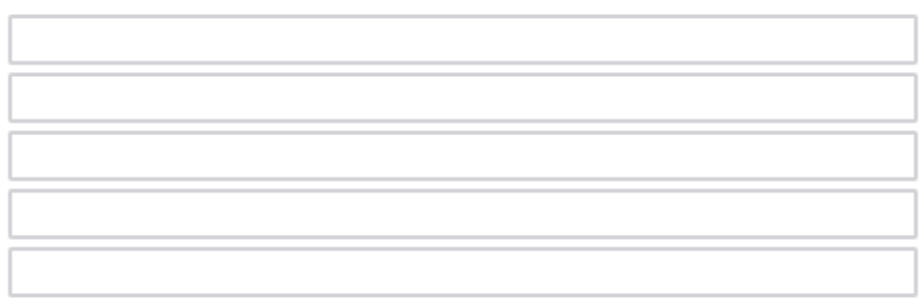

Completeness: Please list any barriers to implementation of entrepreneurial initiatives that you believe are noteworthy.

Barrier 1

Barrier 2

Barrier 3

Barrier 4

Barrier 5

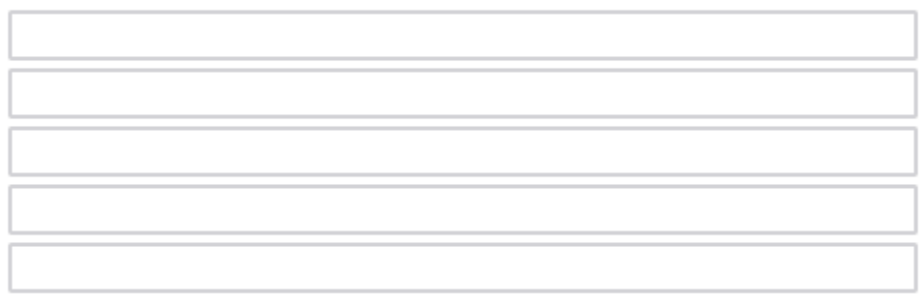




\section{Appendix M: Round 2 Attachment (Round 1 Means Data)}

\section{Student Recruitment}

\begin{tabular}{|c|c|c|c|c|c|}
\hline \multicolumn{6}{|c|}{ Efforts made to recruit beyond the traditional avenues. } \\
\hline \multirow[b]{2}{*}{ Term } & \multicolumn{2}{|c|}{ IMPACT } & \multicolumn{2}{|c|}{ FEASIBILITY } & \multirow[b]{2}{*}{ Definition } \\
\hline & IR & GR & IR & GR & \\
\hline $\begin{array}{l}\text { Third-party recruiting } \\
\text { agents }\end{array}$ & & 2.53 & & 2.61 & $\begin{array}{l}\text { Agencies outside of the college or } \\
\text { university hired specifically for } \\
\text { recruitment purposes. }\end{array}$ \\
\hline Master's by coursework & & 3.39 & & 3.78 & $\begin{array}{l}\text { Students earn a Masters degree } \\
\text { through the completion of } \\
\text { established coursework only, no } \\
\text { thesis is completed. }\end{array}$ \\
\hline $\begin{array}{l}\text { Expedited admissions } \\
\text { decisions }\end{array}$ & & 4.00 & & 3.47 & $\begin{array}{l}\text { Students receive near immediate } \\
\text { admission decisions (could be same } \\
\text { day). }\end{array}$ \\
\hline $\begin{array}{c}\text { Guided pathway } \\
\text { programs for } \\
\text { international populations }\end{array}$ & & 3.42 & & 2.58 & $\begin{array}{l}\text { Program intended to assist students } \\
\text { with language proficiency and } \\
\text { familiarization of socio-cultural } \\
\text { norms. }\end{array}$ \\
\hline $\begin{array}{l}\text { Young professionals } \\
\text { condensed ESL } \\
\text { programs }\end{array}$ & & 3.00 & & 2.41 & $\begin{array}{l}\text { English as a second language } \\
\text { programming that is specifically } \\
\text { designed for students taking college- } \\
\text { level courses. }\end{array}$ \\
\hline $\begin{array}{c}\text { Use of community } \\
\text { college recruiting teams }\end{array}$ & & 3.74 & & 3.47 & $\begin{array}{l}\text { Partnerships or pathways with } \\
\text { community colleges. }\end{array}$ \\
\hline $\begin{array}{c}\text { Foreign-born faculty } \\
\text { student recruitment trips }\end{array}$ & & 2.42 & & 1.95 & $\begin{array}{l}\text { Foreign faculty return to home- } \\
\text { country to recruit student } \\
\text { populations. }\end{array}$ \\
\hline $\begin{array}{c}\text { Customizable degree } \\
\text { programs }\end{array}$ & & 3.68 & & 3.26 & $\begin{array}{l}\text { Students have flexibility in program } \\
\text { pathway and can pick specific } \\
\text { courses for program completion. }\end{array}$ \\
\hline $\begin{array}{l}\text { Enrollment/Retention } \\
\text { Coaching }\end{array}$ & & 3.78 & & 3.17 & $\begin{array}{l}\text { External or internal specialist tasked } \\
\text { with providing constant/consistent } \\
\text { support from initial application } \\
\text { through graduation. }\end{array}$ \\
\hline $\begin{array}{c}\text { In-house } \\
\text { recruiter/enrollment } \\
\text { specialist }\end{array}$ & & 3.74 & & 2.79 & $\begin{array}{l}\text { Professional from within } \\
\text { department/school tasked with only } \\
\text { recruitment/enrollment } \\
\text { responsibilities. }\end{array}$ \\
\hline
\end{tabular}




\begin{tabular}{|c|c|c|c|}
\hline $\begin{array}{c}\text { Consumer-targeted } \\
\text { social media recruitment } \\
\text { strategies }\end{array}$ & 3.50 & 3.50 & $\begin{array}{l}\text { Recruitment materials designed } \\
\text { specifically for college-aged audience } \\
\text { (peer designed using current modes } \\
\text { of communication, i.e. snapchat, } \\
\text { virtual reality, etc.) }\end{array}$ \\
\hline $\begin{array}{c}\text { Enhanced website } \\
\text { content }\end{array}$ & 4.26 & 4.32 & $\begin{array}{l}\text { Websites with in-depth resources } \\
\text { (included but not limited to } \\
\text { information about employability, } \\
\text { salary, careers, etc.) that can be } \\
\text { navigated easily and on mobile } \\
\text { devices. }\end{array}$ \\
\hline $\begin{array}{l}\text { Targeted video and } \\
\text { digital marketing } \\
\text { campaigns }\end{array}$ & 3.74 & 3.26 & $\begin{array}{l}\text { Advertising designed for specific } \\
\text { audiences and distributed } \\
\text { accordingly. }\end{array}$ \\
\hline $\begin{array}{c}\text { Intentional lead } \\
\text { generation efforts }\end{array}$ & 3.41 & 3.06 & $\begin{array}{l}\text { Purposefully collated potential } \\
\text { consumer information used } \\
\text { specifically for recruitment and } \\
\text { enrollment. }\end{array}$ \\
\hline $\begin{array}{c}\text { Explicit career pathways } \\
\text { and experiential learning } \\
\text { opportunities }\end{array}$ & 4.11 & 3.79 & $\begin{array}{l}\text { Advertised career pathways and } \\
\text { experiential learning opportunities, } \\
\text { these may align or begin in } \\
\text { secondary schools. }\end{array}$ \\
\hline $\begin{array}{l}\text { Unique scholarship } \\
\text { strategies }\end{array}$ & 4.00 & 2.95 & Legacy programs, dual-degrees, etc. \\
\hline $\begin{array}{l}\text { Current student and } \\
\text { recent graduate referral } \\
\text { programs }\end{array}$ & 4.11 & 3.95 & $\begin{array}{l}\text { Using the populations listed to aid } \\
\text { with recruitment; benefits may be } \\
\text { provided for enticement of efforts. }\end{array}$ \\
\hline
\end{tabular}

Summer and Intersession Blended Learning

\begin{tabular}{|c|l|l|l|l|l|}
\hline \multicolumn{5}{|c|}{ Learning opportunities that take place outside of the traditional school calendar/semesters. } \\
\hline & IR & GR & IR & GR & \multicolumn{1}{|c|}{ Definition } \\
\hline Term & & 3.00 & & 2.53 & $\begin{array}{l}\text { Students continue to stay on } \\
\text { campus for coursework beyond the } \\
\text { end of spring semester (may } \\
\text { continue course already in progress } \\
\text { or enroll in additional coursework). }\end{array}$ \\
\hline $\begin{array}{c}\text { Extended stay summer } \\
\text { term }\end{array}$ & 3.16 & & 2.89 & $\begin{array}{l}\text { Courses that are often difficult to } \\
\text { register in during fall/spring are } \\
\text { offered in high numbers during } \\
\text { summer to accommodate demand. }\end{array}$ \\
\hline $\begin{array}{c}\text { Oversubscribed course } \\
\text { summer sessions }\end{array}$ & & & & &
\end{tabular}




\begin{tabular}{|c|c|c|c|}
\hline $\begin{array}{l}\text { High-demand major } \\
\text { prerequisite summer } \\
\text { sessions }\end{array}$ & 3.68 & 3.32 & $\begin{array}{l}\text { Prerequisite coursework that is in } \\
\text { high-demand is offered during the } \\
\text { summer session (only or } \\
\text { additionally). }\end{array}$ \\
\hline $\begin{array}{l}\text { Independent study } \\
\text { summer sessions }\end{array}$ & 3.37 & 3.21 & $\begin{array}{l}\text { Students have the flexibility to learn } \\
\text { content through independent } \\
\text { studies (could be used as a } \\
\text { substitute for required coursework } \\
\text { or an elective). }\end{array}$ \\
\hline $\begin{array}{c}\text { Open enrollment } \\
\text { intersession courses }\end{array}$ & 3.16 & 2.68 & $\begin{array}{l}\text { Students may enroll at any point in } \\
\text { time, rather than follow traditional } \\
\text { acceptance timelines. }\end{array}$ \\
\hline $\begin{array}{l}\text { Summer and intersession } \\
\text { financial aid }\end{array}$ & 4.16 & 2.79 & $\begin{array}{l}\text { Monetary support to aid students } \\
\text { with the costs of higher education } \\
\text { coursework. }\end{array}$ \\
\hline $\begin{array}{l}\text { General education } \\
\text { requirement blended } \\
\text { courses }\end{array}$ & 3.74 & 3.37 & $\begin{array}{l}\text { Courses that fulfill general } \\
\text { education requirements through } \\
\text { both online and face-to-face } \\
\text { formats, allowing for more flexibility } \\
\text { in learners location. }\end{array}$ \\
\hline $\begin{array}{c}\text { Study abroad makeup } \\
\text { courses }\end{array}$ & 3.21 & 2.63 & $\begin{array}{l}\text { Students may take courses that are } \\
\text { missed in a program or study or } \\
\text { failed while completing a study } \\
\text { abroad experience. }\end{array}$ \\
\hline $\begin{array}{l}\text { Experiential learning } \\
\text { opportunities }\end{array}$ & 4.53 & 4.26 & $\begin{array}{l}\text { Experiences outside a traditional } \\
\text { academic setting that enable } \\
\text { students to develop knowledge, } \\
\text { skills, and values. }\end{array}$ \\
\hline $\begin{array}{l}\text { Co-ops/internship } \\
\text { placements }\end{array}$ & 4.42 & 3.89 & $\begin{array}{l}\text { Work placements (may be paid) } \\
\text { that occur throughout the traditional } \\
\text { plan of study and count for } \\
\text { academic credit. }\end{array}$ \\
\hline $\begin{array}{l}\text { Specialized events for } \\
\text { current students/alumni }\end{array}$ & 3.58 & 3.42 & $\begin{array}{l}\text { College/University organized events } \\
\text { centered around networking, } \\
\text { recruitment visits, and targeted list- } \\
\text { purchases. }\end{array}$ \\
\hline
\end{tabular}

Distance Learning Articulation Agreements

\begin{tabular}{|c|c|c|c|c|c|}
\hline \multicolumn{6}{|c|}{ Agreements established to benefit distance learners. } \\
\hline & \multicolumn{2}{|c|}{ IMPACT } & \multicolumn{2}{|c|}{ FEASBILITY } & \\
\hline Term & IR & GR & IR & GR & Definition \\
\hline
\end{tabular}




\begin{tabular}{|c|c|c|c|}
\hline $\begin{array}{l}\text { Out of state community } \\
\text { college online programs }\end{array}$ & 2.67 & 2.33 & $\begin{array}{l}\text { Students may take community } \\
\text { college courses online and receive } \\
\text { in-state advantages (ie. tuition } \\
\text { costs). }\end{array}$ \\
\hline $\begin{array}{c}\text { Blended } \\
\text { courses/programs }\end{array}$ & 3.50 & 3.33 & $\begin{array}{l}\text { Coursework or entire programs } \\
\text { completed both online and face-to- } \\
\text { face. }\end{array}$ \\
\hline $\begin{array}{c}\text { Online dual enrollment } \\
\text { programs }\end{array}$ & 3.28 & 2.89 & $\begin{array}{l}\text { Enrolling students who may be } \\
\text { studying at another institution (this } \\
\text { may be higher education or } \mathrm{K} 12 \text { ). }\end{array}$ \\
\hline $\begin{array}{l}\text { Dual-degree programs } \\
\text { with other universities }\end{array}$ & 3.00 & 2.33 & $\begin{array}{l}\text { Working to earn degrees } \\
\text { simultaneously from more than one } \\
\text { university or possibly working to } \\
\text { complete one degree from more } \\
\text { than one partnering institution. }\end{array}$ \\
\hline $\begin{array}{l}\text { Articulations with private } \\
\text { companies/organizations }\end{array}$ & 2.94 & 2.39 & $\begin{array}{l}\text { Agreements with private } \\
\text { companies/organizations to offer } \\
\text { educational credits or coursework. }\end{array}$ \\
\hline $\begin{array}{l}\text { International institution } \\
\text { graduate partnership } \\
\text { agreements }\end{array}$ & 3.17 & 2.50 & $\begin{array}{l}\text { Institutions that partner with } \\
\text { academic institutions across the } \\
\text { globe to expand curricular } \\
\text { offerings, research collaborations, } \\
\text { and intercultural opportunities for } \\
\text { mobility of graduate students. }\end{array}$ \\
\hline International partnerships & 3.00 & 2.67 & $\begin{array}{l}\text { Partnerships with particular } \\
\text { countries. }\end{array}$ \\
\hline $\begin{array}{l}\text { Online employment skills } \\
\text { certificate programs }\end{array}$ & 2.67 & 3.00 & $\begin{array}{l}\text { Programs designed to teach } \\
\text { employable skills/knowledge that } \\
\text { cannot be automated. }\end{array}$ \\
\hline
\end{tabular}

Distance Learning Course Licensing

\begin{tabular}{|c|l|l|l|l|l|}
\hline \multicolumn{5}{|c|}{ Faculty or higher education professionals develop materials that can be distributed for profit. } \\
\hline & \multicolumn{2}{|c|}{ IMPACT } & \multicolumn{2}{|c|}{ FEASIBILITY } & \\
\hline Term & IR & GR & IR & GR & \multicolumn{1}{|c|}{ Definition } \\
\hline $\begin{array}{c}\text { Recreational learning } \\
\text { brand licensing }\end{array}$ & 2.26 & & 1.95 & $\begin{array}{l}\text { Creation of a learning brand that } \\
\text { can be owned and used to create } \\
\text { products under one name. }\end{array}$ \\
\hline $\begin{array}{c}\text { Turnkey homeschool } \\
\text { curriculum }\end{array}$ & 2.06 & & 2.24 & $\begin{array}{l}\text { Homeschool curriculum that can be } \\
\text { sold and used with no prior } \\
\text { knowledge or education on the } \\
\text { subject matter. }\end{array}$ \\
\hline
\end{tabular}




\begin{tabular}{|c|l|l|l|l|l|}
\hline $\begin{array}{c}\text { Capstone case study } \\
\text { sales }\end{array}$ & 2.33 & & 2.53 & $\begin{array}{l}\text { Capstone experiences that are } \\
\text { designed to be recreated by the } \\
\text { masses. }\end{array}$ \\
\hline $\begin{array}{c}\text { International course } \\
\text { sales }\end{array}$ & 2.05 & & 2.05 & $\begin{array}{l}\text { Courses that can be sold globally } \\
\text { (translated before sale or easily } \\
\text { translated by consumer) }\end{array}$ \\
\hline
\end{tabular}

\section{Applied and Professional Masters}

\begin{tabular}{|c|c|c|c|c|c|}
\hline \multicolumn{6}{|c|}{ Non-traditional students are able to earn a Masters degree through non-traditional means. } \\
\hline \multirow[b]{2}{*}{ Term } & \multicolumn{2}{|c|}{ IMPACT } & \multicolumn{2}{|c|}{ FEASBILITY } & \multirow[b]{2}{*}{ Definition } \\
\hline & IR & GR & IR & GR & \\
\hline $\begin{array}{l}\text { On-demand new cohort } \\
\text { programs }\end{array}$ & & 3.22 & & 2.33 & $\begin{array}{l}\text { Programs are started based on } \\
\text { consumer demand (created or start } \\
\text { date). }\end{array}$ \\
\hline $\begin{array}{l}\text { Professional science } \\
\text { Masters }\end{array}$ & & 3.41 & & 2.88 & $\begin{array}{l}\text { Designed in partnership with } \\
\text { employers and feature learning in } \\
\text { real-world environments. }\end{array}$ \\
\hline $\begin{array}{l}\text { Interdisciplinary terminal } \\
\text { Masters }\end{array}$ & & 2.94 & & 2.82 & $\begin{array}{l}\text { Creation of a terminal Masters (no } \\
\text { higher degree in that area) that } \\
\text { covers multiple fields of } \\
\text { knowledge. }\end{array}$ \\
\hline Weekend course Masters & & 3.28 & & 2.89 & $\begin{array}{l}\text { Masters is earned through the } \\
\text { completion of intensive weekend- } \\
\text { long or weekend-driven } \\
\text { coursework. }\end{array}$ \\
\hline $\begin{array}{c}\text { Applied liberal arts } \\
\text { Masters }\end{array}$ & & 2.31 & & 2.63 & $\begin{array}{l}\text { Students earn a degree in a wide } \\
\text { range of transferable skills and } \\
\text { knowledge, rather than one content } \\
\text { area/field. }\end{array}$ \\
\hline Stackable certificates & & 3.18 & & 3.53 & $\begin{array}{l}\text { Students create a sequence of } \\
\text { credentials over time to build up } \\
\text { their qualifications. }\end{array}$ \\
\hline $\begin{array}{l}\text { New regulatory } \\
\text { requirement certificates }\end{array}$ & & 3.24 & & 3.00 & $\begin{array}{l}\text { Certificates offered to meet the } \\
\text { demands of the marketplace and } \\
\text { regulatory requirements. }\end{array}$ \\
\hline $\begin{array}{l}\text { Accelerated degree } \\
\text { programs }\end{array}$ & & 4.17 & & 3.67 & $\begin{array}{l}\text { Students are able to overlap their } \\
\text { degree work and complete an } \\
\text { advanced curriculum to earn } \\
\text { multiple degrees in a shorter } \\
\text { timeframe (i.e. 3-yr BS; BS-MS; } \\
\text { etc.) }\end{array}$ \\
\hline
\end{tabular}




\begin{tabular}{|c|c|c|c|}
\hline $\begin{array}{l}\text { Microcredentialing and } \\
\text { nanodegrees }\end{array}$ & 2.47 & 2.24 & $\begin{array}{l}\text { The repackaging of selected } \\
\text { content for a targeted purpose (and } \\
\text { for individuals in possession of } \\
\text { bachelor's degrees that have not } \\
\text { provided "pathways to top jobs"). }\end{array}$ \\
\hline Digital Badging & 2.69 & 3.13 & $\begin{array}{l}\text { A validated indicator of } \\
\text { accomplishment, skill, quality, or } \\
\text { interest that can be earned in many } \\
\text { learning environments. }\end{array}$ \\
\hline Employee-based cohorts & 3.13 & 3.00 & $\begin{array}{l}\text { Cohorts created and enrolled only } \\
\text { with employees of particular } \\
\text { companies. }\end{array}$ \\
\hline $\begin{array}{l}\text { Discounted pricing for } \\
\text { professional-based } \\
\text { cohorts }\end{array}$ & 3.41 & 2.41 & $\begin{array}{l}\text { Cheaper fees or tuition for cohorts } \\
\text { enrolled with working } \\
\text { professionals. }\end{array}$ \\
\hline Flexible term start & 3.17 & 2.22 & $\begin{array}{l}\text { Students can enroll in programs at } \\
\text { different parts of the academic year } \\
\text { (spring, summer, or fall). Students } \\
\text { may also be able to enroll at } \\
\text { different intervals throughout a } \\
\text { particular semester. }\end{array}$ \\
\hline $\begin{array}{l}\text { Fully online lifetime } \\
\text { portfolio }\end{array}$ & 2.81 & 2.88 & $\begin{array}{l}\text { Learning portfolios that can follow } \\
\text { a student throughout multiple } \\
\text { degrees (BS, MS, EDD, CPD). }\end{array}$ \\
\hline
\end{tabular}

\section{Customized Corporate Training and Partnerships}

\begin{tabular}{|c|c|c|c|c|c|}
\hline \multicolumn{6}{|c|}{ Higher education institutions work with corporations to create and/or administer training. } \\
\hline \multirow[b]{2}{*}{ Term } & \multicolumn{2}{|c|}{ IMPACT } & \multicolumn{2}{|c|}{ FEASBILITY } & \multirow[b]{2}{*}{ Definition } \\
\hline & IR & GR & IR & GR & \\
\hline Career path maps & & 3.29 & & 3.35 & $\begin{array}{l}\text { The development of career paths } \\
\text { or career ladders that can be used } \\
\text { by a corporation for its employees } \\
\text { to follow. }\end{array}$ \\
\hline $\begin{array}{c}\text { Online professional } \\
\text { Masters }\end{array}$ & & 3.72 & & 3.83 & $\begin{array}{l}\text { A professional masters that can be } \\
\text { achieved through solely online } \\
\text { coursework. }\end{array}$ \\
\hline $\begin{array}{l}\text { After-hours course } \\
\text { scheduling }\end{array}$ & & 3.67 & & 3.22 & $\begin{array}{l}\text { Course scheduling that meets the } \\
\text { demands of full-time employees. }\end{array}$ \\
\hline $\begin{array}{l}\text { Rapid-cycle customized } \\
\text { curriculum offerings }\end{array}$ & & 3.29 & & 2.59 & $\begin{array}{l}\text { A curriculum that is developed with } \\
\text { flexibility in mind. May change to }\end{array}$ \\
\hline
\end{tabular}




\begin{tabular}{|c|c|c|c|}
\hline & & & $\begin{array}{l}\text { meet consumer demand at any } \\
\text { point. }\end{array}$ \\
\hline $\begin{array}{l}\text { Templatized company } \\
\text { policies }\end{array}$ & 2.81 & 2.81 & $\begin{array}{l}\text { Universities/colleges would take } \\
\text { part in developing templates that } \\
\text { can be used by corporations to } \\
\text { help educate employees on } \\
\text { policies and other pertinent } \\
\text { information. }\end{array}$ \\
\hline $\begin{array}{l}\text { Corporate advisory } \\
\text { committees }\end{array}$ & 3.00 & 3.28 & $\begin{array}{l}\text { Committees that are used to advise } \\
\text { corporations on education } \\
\text { elements related to their } \\
\text { businesses. }\end{array}$ \\
\hline $\begin{array}{l}\text { Referral programs of } \\
\text { potential employers }\end{array}$ & 3.72 & 3.50 & $\begin{array}{l}\text { Programs that connect potential } \\
\text { employers directly to graduates of } \\
\text { degree programs. }\end{array}$ \\
\hline $\begin{array}{l}\text { Partnerships with non- } \\
\text { profits and professional } \\
\text { associations }\end{array}$ & 3.82 & 3.67 & $\begin{array}{l}\text { Institution partnerships with non- } \\
\text { profits or professional associations } \\
\text { that have a shared purpose or field. }\end{array}$ \\
\hline $\begin{array}{c}\text { Corporate initiatives for } \\
\text { underserved }\end{array}$ & 3.78 & 3.11 & $\begin{array}{l}\text { Partnerships with } \\
\text { colleges/universities and } \\
\text { corporations that seek to develop } \\
\text { initiatives to identify and serve } \\
\text { underserved populations. }\end{array}$ \\
\hline $\begin{array}{l}\text { Continuing professional } \\
\text { development for } \\
\text { corporations }\end{array}$ & 3.61 & 3.44 & $\begin{array}{l}\text { Offering coursework and learning } \\
\text { opportunities directly related to the } \\
\text { needs of continued professional } \\
\text { development. }\end{array}$ \\
\hline $\begin{array}{c}\text { Tuition breaks for } \\
\text { partnering companies }\end{array}$ & 3.44 & 2.61 & $\begin{array}{l}\text { Discounted tuition or agreements } \\
\text { designed specifically for partner } \\
\text { companies. }\end{array}$ \\
\hline $\begin{array}{c}\text { Recognition of company } \\
\text { training as degree } \\
\text { pursuant }\end{array}$ & 3.53 & 3.00 & $\begin{array}{l}\text { Company training that can be } \\
\text { applied to degree programs as } \\
\text { credit worthy coursework. }\end{array}$ \\
\hline
\end{tabular}

\section{Seniors' Enrichment Programs}

\begin{tabular}{|c|c|c|c|c|c|}
\hline \multicolumn{6}{|c|}{ Programs that are aimed at lifelong learning experiences and senior populations. } \\
\hline & \multicolumn{2}{|c|}{ IMPACT } & \multicolumn{2}{|c|}{ FEASBILITY } & \\
\hline Term & IR & GR & IR & GR & \multicolumn{1}{|c|}{ Definition } \\
\hline Couples' memberships & & 2.67 & & 2.76 & $\begin{array}{l}\text { Students who enroll as partners are } \\
\text { able to receive perks. }\end{array}$ \\
\hline
\end{tabular}




\begin{tabular}{|c|c|c|c|}
\hline $\begin{array}{l}\text { Expanded course audit } \\
\text { catalogs }\end{array}$ & 2.50 & 2.94 & $\begin{array}{l}\text { The courses that a student can audit } \\
\text { are greatly expanded. }\end{array}$ \\
\hline $\begin{array}{l}\text { Priced-to-market course } \\
\text { audit fees }\end{array}$ & 2.50 & 2.47 & $\begin{array}{l}\text { Courses are priced based on the } \\
\text { demand for the product. }\end{array}$ \\
\hline Local excursion weekends & 2.83 & 2.82 & $\begin{array}{l}\text { Students are able to enroll in } \\
\text { excursions that are produced } \\
\text { through the university/college. }\end{array}$ \\
\hline $\begin{array}{l}\text { Faculty-led destination } \\
\text { travel }\end{array}$ & 3.33 & 2.94 & $\begin{array}{l}\text { Faculty lead destination trips that } \\
\text { can be taken by senior students and } \\
\text { have an educational component. }\end{array}$ \\
\hline $\begin{array}{l}\text { Osher lifelong learning } \\
\text { grants }\end{array}$ & 3.24 & 3.00 & $\begin{array}{l}\text { Osher grants that are established } \\
\text { specifically for mature populations. }\end{array}$ \\
\hline $\begin{array}{l}\text { College-affiliated retirement } \\
\text { communities }\end{array}$ & 3.00 & 2.44 & $\begin{array}{l}\text { Retirement communities that have } \\
\text { an affiliation with a } \\
\text { college/university. }\end{array}$ \\
\hline Multi-generational activities & 3.00 & 2.81 & $\begin{array}{l}\text { College/university-sponsored } \\
\text { activities that simultaneously cater } \\
\text { to multi-generational groups. }\end{array}$ \\
\hline $\begin{array}{l}\text { Sport and eco-tourism } \\
\text { approaches }\end{array}$ & 3.72 & 3.06 & $\begin{array}{l}\text { College/university tours or trips that } \\
\text { are related to sport and eco-tourism. }\end{array}$ \\
\hline $\begin{array}{c}\text { Faculty-led inter- } \\
\text { generational study abroad } \\
\text { trips }\end{array}$ & 3.11 & 3.00 & $\begin{array}{l}\text { Study abroad trips that cater to } \\
\text { several generations, led specifically } \\
\text { by faculty. }\end{array}$ \\
\hline Enrichment courses & 3.22 & 3.29 & $\begin{array}{l}\text { Courses that are used as continued } \\
\text { learning to enrich senior knowledge } \\
\text { in specific content areas. }\end{array}$ \\
\hline $\begin{array}{l}\text { Themed yearly lecture } \\
\text { series }\end{array}$ & 3.56 & 3.94 & $\begin{array}{l}\text { College/university sponsored } \\
\text { lectures that are open or marketed } \\
\text { to senior age learners. }\end{array}$ \\
\hline
\end{tabular}

Testing and Certification

\begin{tabular}{|c|c|c|c|c|c|}
\hline \multicolumn{6}{|c|}{ Any testing or certification materials that are created or marketed by a higher education institution. } \\
\hline & \multicolumn{2}{|c|}{ IMPACT } & \multicolumn{2}{|c|}{ FEASBILITY } & \\
\hline Term & IR & GR & IR & GR & Definition \\
\hline
\end{tabular}




\begin{tabular}{|c|c|c|c|}
\hline $\begin{array}{l}\text { Professional society testing } \\
\text { partnerships }\end{array}$ & 3.22 & 3.06 & $\begin{array}{l}\text { Partnerships with any professional } \\
\text { community with the objective to } \\
\text { create testing materials. }\end{array}$ \\
\hline ESL testing and certification & 2.89 & 2.56 & $\begin{array}{l}\text { Creation or distribution of ESL } \\
\text { testing or certification materials. }\end{array}$ \\
\hline $\begin{array}{l}\text { Distance learning proctoring } \\
\text { services }\end{array}$ & 3.35 & 3.44 & $\begin{array}{l}\text { Universities serve as a site to } \\
\text { proctor examines in a controlled } \\
\text { setting for distance learners. }\end{array}$ \\
\hline Placement test fees & 2.33 & 2.61 & $\begin{array}{l}\text { Earnings that are related to } \\
\text { placement tests. }\end{array}$ \\
\hline $\begin{array}{l}\text { For-profit educator testing } \\
\text { site rental }\end{array}$ & 2.41 & 2.59 & $\begin{array}{l}\text { Universities serve as a site for } \\
\text { students to complete elements of } \\
\text { programs that need to be taken in } \\
\text { face-to-face format. }\end{array}$ \\
\hline Online remedial programs & 2.89 & 2.83 & $\begin{array}{l}\text { Universities and colleges create } \\
\text { remedial programs that can be taken } \\
\text { to aid students in common issue } \\
\text { areas. }\end{array}$ \\
\hline $\begin{array}{l}\text { Coaching certification } \\
\text { programs }\end{array}$ & 3.82 & 4.00 & $\begin{array}{l}\text { Institutions create certification } \\
\text { programs for coaching. }\end{array}$ \\
\hline $\begin{array}{l}\text { Building testing and testing } \\
\text { prep into the curriculum }\end{array}$ & 3.33 & 3.44 & $\begin{array}{l}\text { Colleges build mandated/regulated } \\
\text { testing and preparation into the } \\
\text { curriculum so it can be paid for with } \\
\text { financial aid funds and not out of } \\
\text { pocket. }\end{array}$ \\
\hline $\begin{array}{l}\text { Diagnostic testing in clinical } \\
\text { settings }\end{array}$ & 3.39 & 2.89 & $\begin{array}{l}\text { Medical testing that can be offered } \\
\text { through clinical settings, benefitting } \\
\text { the learner and the consumer. }\end{array}$ \\
\hline
\end{tabular}

Faculty Consulting

\begin{tabular}{|c|c|c|c|c|l|}
\hline \multicolumn{5}{|c|}{ Faculty uses their knowledge and expertise in the role of a consultant. } \\
\hline & \multicolumn{2}{|c|}{ IMPACT } & \multicolumn{2}{|c|}{ FEASIBILITY } & \\
\hline Term & IR & GR & IR & GR & \multicolumn{1}{|c|}{ Definition } \\
\hline $\begin{array}{c}\text { International university } \\
\text { curriculum consulting }\end{array}$ & & 2.78 & & 3.00 & $\begin{array}{l}\text { Faculty consults on the creation of } \\
\text { an international university } \\
\text { curriculum. }\end{array}$ \\
\hline Faculty expertise databases & & 3.28 & & 3.56 & $\begin{array}{l}\text { Faculty creates databases driven } \\
\text { by their expertise that can aid } \\
\text { outside communities. }\end{array}$ \\
\hline
\end{tabular}




\begin{tabular}{|c|l|l|l|l|l|}
\hline $\begin{array}{c}\text { Industry sponsored } \\
\text { capstone projects }\end{array}$ & 3.56 & & 3.22 & $\begin{array}{l}\text { Faculty consults on the creation of } \\
\text { industry-driven capstone projects. }\end{array}$ \\
\hline Nurse practitioner practices & & 3.00 & & 2.94 & $\begin{array}{l}\text { Faculty consults on practitioner } \\
\text { practices. }\end{array}$ \\
\hline Personal training & & 3.44 & & 3.78 & $\begin{array}{l}\text { The faculty is consultants in a } \\
\text { personal training context. }\end{array}$ \\
\hline Therapy sessions & & 2.89 & & 2.72 & $\begin{array}{l}\text { Faculty provides therapy (physical, } \\
\text { emotional, mental) based on } \\
\text { expertise (maybe through a clinic). }\end{array}$ \\
\hline Exercise testing & \multicolumn{2}{|l|}{ ADDITION BY PANEL MEMBER } & \\
\hline Exercise Prescription & \multicolumn{2}{|l|}{ ADDITION BY PANEL MEMBER } & \\
\hline
\end{tabular}




\section{Community Partnerships}

\begin{tabular}{|c|c|c|c|c|c|}
\hline \multicolumn{6}{|c|}{ Universities/colleges establish partnerships with local communities. } \\
\hline \multirow[b]{2}{*}{ Term } & \multicolumn{2}{|c|}{ IMPACT } & \multicolumn{2}{|c|}{ FEASBILITY } & \multirow[b]{2}{*}{ Definition } \\
\hline & IR & GR & IR & GR & \\
\hline Summer youth camps & & 3.67 & & 3.33 & $\begin{array}{l}\text { Universities/colleges create } \\
\text { and facilitate summer youth } \\
\text { camps related to content or } \\
\text { activities held on campus. }\end{array}$ \\
\hline Community activity programs & & 3.53 & & 3.71 & $\begin{array}{l}\text { Universities/colleges create } \\
\text { and facilitate community } \\
\text { activity programs related to } \\
\text { content or activities held on } \\
\text { campus. }\end{array}$ \\
\hline Community lectures & & 3.22 & & 4.06 & $\begin{array}{l}\text { Universities/colleges provide } \\
\text { the community with lectures } \\
\text { by faculty or staff members. }\end{array}$ \\
\hline $\begin{array}{l}\text { Multi-generational activity } \\
\text { opportunities }\end{array}$ & & 3.18 & & 3.28 & $\begin{array}{l}\text { Classes or activities that } \\
\text { cater to multiple generations } \\
\text { at the same time. }\end{array}$ \\
\hline $\begin{array}{l}\text { Community/professional } \\
\text { associations sponsored } \\
\text { presentations/outreach }\end{array}$ & & 3.50 & & 3.83 & $\begin{array}{l}\text { Outside organizations } \\
\text { sponsor presentations that } \\
\text { can be conducted by } \\
\text { college/university faculty or } \\
\text { staff. }\end{array}$ \\
\hline $\begin{array}{c}\text { Under-served populations } \\
\text { focused/incentivized } \\
\text { programs }\end{array}$ & & 3.83 & & 3.28 & $\begin{array}{l}\text { Programs designed to focus } \\
\text { on underserved populations } \\
\text { or incentives that drive this } \\
\text { consumer base in. }\end{array}$ \\
\hline $\begin{array}{l}\text { Public school career } \\
\text { academy partnerships }\end{array}$ & & 3.83 & & 3.39 & $\begin{array}{l}\text { Partnerships created } \\
\text { between post-secondary } \\
\text { institutions and secondary } \\
\text { career academies to help } \\
\text { create pathways to learning. }\end{array}$ \\
\hline
\end{tabular}




\title{
Appendix N: Curriculum Vitae
}

\section{Ms. Cory L. Breithoff}

\author{
119 Yellow Breeches Drive \\ Camp Hill, PA \\ (908) 310-9104 \\ cbreitho@hotmail.com \\ linkedin.com/in/cory-breithoff
}

\section{SUMMARY OF QUALIFICATIONS}

\section{Scholarship of Teaching and Learning}

- Received highly favorable performance reviews in the area of teaching effectiveness for courses taught at both K-12 and undergraduate levels at multiple institutions.

- Planned, managed, implemented, and assessed effective teaching-learning environments in Physical Education Teacher Education.

- Assisted with experiential learning opportunities for undergraduate students in a variety of applied instructional settings including field experiences and student teaching.

- Mentored undergraduate students and colleagues regarding course design, instructional methods, assessing student learning, and field placement supervision.

- Established skill in using word processing, spreadsheet, presentation, online course management systems, and discipline-specific software to enhance the teaching-learning environment.

\section{Scholarship of Discovery and Integration}

- Delivered peer-reviewed presentations on a state and national level.

- Collaborated with faculty and colleagues on a variety of research topics.

\section{Scholarship of Application}

- Demonstrated collaborative leadership, strong communication skills, high degree of personal initiative, excellent problem-solving ability, strategic decision-making, and capacity to contribute to organizational change while serving as a student advisory board President within an academic department and member of various department committees.

- Coordinated assessment data collection and management for SHAPE/CAEP accreditation in a nationally recognized teacher education program.

\section{ACADEMIC PREPARATION}

Doctor of Philosophy, West Virginia University, Morgantown, WV

2016- 2020

Program: Kinesiology

Major: Coaching and Teaching Studies

Cognate: Higher Education Leadership

Master of Science, West Virginia University, Morgantown, WV

2014- 2016

Major: Physical Education Teacher Education 
Bachelor of Science, West Virginia University, Morgantown, WV

2007-2011

Major: Physical Education Teacher Education

Minor: Health Education

Graduation Honors: Summa Cum Laude

\section{RESEARCH AND TEACHING INTERESTS}

Research: Innovative leadership in higher education; Alternative revenue generation;

Professional issues in teacher education and higher education; Scholarship of teaching and learning;

Capstone courses and senior year experience.

Teaching: Introductory and capstone courses in physical education and related fields; Pedagogical content knowledge courses; physical education curriculum; Assessment techniques; Field placements, internships, and experiential learning.

\section{EMPLOYMENT HISTORY}

Physical Education and Health Teacher

2019-Present Central Dauphin East High School, Central Dauphin School District, Harrisburg, PA

Instruct physical education and health education in a comprehensive and inclusive environment. Serve as temporary department head during transition to online teaching period.

Physical Education and Health Teacher

2017- 2019

University High School, Monongalia County Schools, Morgantown, WV

Instruct physical education and health education in a comprehensive and inclusive environment.

Coordinate with WVU campus instructors to ensure a smooth transition for student teachers in the publicschool setting. Supervise student teachers during semester placements and early teacher preparation students in modified placements.

Graduate Teaching Assistant

2014- 2017

West Virginia University, College of Physical Activity and Sports Sciences

Educated undergraduates in physical education teacher education (PETE), athletic coaching education, and basic instruction courses. Coordinated student teaching placements, as well as instructed student teaching seminar in PETE. Communicated and assessed teacher candidates on and off campus through multiple clinical placements. Assisted with implementation of edTPA for student teachers, including uploading files to LiveText for assessment. Served as a mentor for accelerated bachelors to masters students. Worked closely with department faculty during the CAEP accreditation process.

Physical Education and Health Teacher

2013- 2014

Hunterdon Central Regional High School, Flemington, NJ

Applied a variety of learning strategies, focusing highly on technology integration as a means to support literacy development. Introduced and refined application of sport education; accompanied in the research and development of curriculum; developed systematic approach to evaluate teacher performance in regard to $\mathrm{NJ}$ student growth objectives.

District Substitute

2009- 2013

Delaware Valley Regional High School, Frenchtown, NJ

Instructed in long term special education paraprofessional positions; provided daily instruction in physical education/health/driver education as well as other subjects. 
District Substitute

2011- 2013

Flemington-Raritan School District, Flemington, NJ

Provided daily instruction in physical education/health as well as other subjects at multiple educational levels.

\section{HIGHER EDUCATION TEACHING EXPERIENCE}

West Virginia University

Spring Semester 2017

ACE 106 Introduction to ACE

PET 477 Adapted Physical Education*

PET 488 Student Teaching*

PET 489 Student Teaching Seminar

PET 167 Introduction to PETE

Spring Semester 2016

PE 160 Beginning Tennis

PE 170 Volleyball*

PE 206 Modified Indoor Tennis*

PET 477 Adapted Physical Education*

PET 493H Teaching of Volleyball

PET 493I Teaching of Badminton/Pickleball

Spring Semester 2015

PE 160 Beginning Tennis

PE 170 Volleyball*

PET 477 Adapted Physical Education*

PET 493H Teaching of Volleyball

*Indicates supervisory role
Fall Semester 2016

ACE 106 Introduction to ACE

PE 101 Badminton*

PE 206 Modified Indoor Tennis*

PET 447 Teaching Physical Activities 3

PET 477 Adapted Physical Education*

PET 167 Introduction to PETE

Fall Semester 2015

ACE 366 Techniques of Coaching Volleyball

PE 160 Beginning Tennis

PE 170 Volleyball*

PE 206 Modified Indoor Tennis*

PET 477 Adapted Physical Education*

PET 493H Teaching of Volleyball

Fall Semester 2014

PE 160 Beginning Tennis

PE 162 Intermediate Tennis

PE 165 Conditioning*

PE 170 Volleyball*

PET 339 Teaching of Volleyball 


\section{ADDITIONAL EXPERIENCE}

Instructor and Judge

2014 - 2020

\section{Universal Cheerleaders Association}

Trained co-workers and cheerleaders as well as worked with coaches to fulfill their goals. Experiences included working a number of summer camps and clinics, judging local, regional, and national competitions, and competitive choreography.

High School Cheerleading Coach

$2012-2014$

Hunterdon Central Regional High School, Flemington, NJ

Coach for nationally ranked/State Champion Team; organized, developed and implemented practice plans for the 2012-2013 and 2013-2014 seasons.

Gymnastics Instructor

$2011-2013$

HealthQuest Fitness, Flemington, NJ

Planned daily youth gymnastics and cheerleading lessons ranging from kindergarten-high school age athletes; created assessment rubrics to help chart athletes progress and set goals for future development.

Youth Camp Counselor

2011

HealthQuest Fitness, Flemington, NJ

Designed and organized curriculum for themed camps for children ages 3-15; delegated responsibilities and teaching plans to assistant counselors.

\section{PROFESSIONAL CERTIFICATIONS}

\section{Pennsylvania Emergency Teaching Certificate}

Physical Education, Health Education

Title signifies that requirements are in the process of being met in the state of Pennsylvania.

\section{West Virginia Professional Teaching Certificate:}

\section{Physical Education (PK-AD), Health Education (PK-AD)}

Title signifies that all requirements by law and the West Virginia Board of Education have been met and candidate is thereby granted this license which is valid in the schools of the state as endorsed.

New Jersey Standard Teaching Certificates:

Physical Education, Health Education, Driver Education

Title signifies that all requirements established by the State Board of Education have been met and candidate is thereby authorized to serve in the public schools of New Jersey.

\section{Quality Matters, Online Instructional Design}

Title acknowledges completion of online instructional training related to independent application of the Quality Matters rubric (APPQMR) for Statewide Systems.

\section{Let's Move Active Schools, Physical Activity Leader}

Title acknowledges completion of all necessary training for Let's Move Active Schools Physical Activity Leaders related to school-based programs and initiatives. 
National Federation of State High School Associations, Coaching Principles Certification

Title acknowledges completion of NFHS Coaching Principles coursework as it relates to National and State coaching guidelines.

National Federation of State High School Associations, American Association of Cheerleading Coaches and Administration, Spirit Safety Certification

Title acknowledges completion of NFHS and AACCA Spirit Safety coursework as it relates to National coaching guidelines.

\section{PRESENTATIONS}

Breithoff, C. L., Keath, A., Elliott, E., Bulger, S. M., \& Watterson, T. (2019, April). Big Brother: The Reality of Hiring Practices in the $21^{\text {st }}$ Century. Society for Health and Physical Educations National Conference, Tampa, FL.

Breithoff, C. L., Keath, A., Elliott, E., Bulger, S. M., \& Baek, J. (2018, March). Google it: Students' Perceptions of Digital Presence on Future Employability. Society for Health and Physical Educations National Conference, Nashville, TN.

Breithoff, C. L., Taliaferro, A., Bulger, S. M., \& Jones, E. M. (2017, July). Learning to Differentiate Instruction in Student Teaching: The Need for Greater Intentionality. National Consortium for Physical Education for Individuals with Disabilities National Convention, Washington, DC.

Breithoff, C. L. \& Bulger, S. M. (2017, October). Flip it! Active Learning Strategies for the Classroom. West Virginia Association for Health, Physical Education, Recreation \& Dance State Convention, Shepardstown, WV.

Towner, B. C., Breithoff, C. L., \& Kipfer, H. J. (2017, October). Take the Lead: Integrating PA into After-School Programs. West Virginia Association for Health, Physical Education, Recreation \& Dance State Convention, Shepardstown, WV.

Bulger, S. M., Jones, E. M., \& Breithoff, C. L. (2016, October). Continuing Professional Development Opportunities for Teachers. West Virginia Association for Health, Physical Education, Recreation \& Dance State Convention, Glade Springs, WV.

Breithoff, C. L. \& Keath, A. (2016, November). Albert Gallatin Area School District Professional Development Presentation, Smithfield, PA.

Breithoff, C. L. \& Keath, A. (2016, September). 21st CCLC-Boys \& Girls Clubs of Marion County Presentation, Fairmont, WV.

Keath, A. \& Breithoff, C. L. (2016, April). Integrating Physical Activity into $21^{\text {st }}$ CCLC Programs. $21^{\text {st }}$ Century Community Learning Centers Workshop, Morgantown, WV.

\section{PUBLICATIONS}

Hash, K. M., Roy, A., Breithoff, C. L., Dubina, N., Maust, D., Englehardt, J. (Submitted). Gerontology practitioner certificate: Program evaluation and recommendations for improvement. Journal of Teaching in Social Work. 
Breithoff, C. L., Keath, A., Elliott, E., Bulger, S. M., \& Watterson, T. (in progress). Big brother: The effect of digital presence on teacher candidate employability.

Breithoff, C. L., Taliaferro, A., Bulger, S. M. \& Jones, E. M. (in progress). Learning to differentiate instruction in student teaching: The need for greater intentionality.

\section{GIFTS AND GRANTS}

Wyant, K. \& Breithoff, C. L. (2019). Creating a Healthy School Environment. Submitted to Highmark Foundation. (\$5,000, not funded) ---Co-investigator

Breithoff, C. L. (2017). Small Equipment Donation on behalf of University High School. Submitted to Dick’s Sporting Goods. (\$100 funded)

Bulger, S.M., Voelker, D., \& Breithoff, C. L. (2017). Trading Spaces, Pedagogies, and Technologies: Using Professional Learning Communities to Develop, Implement, and Evaluate a University Active Learning Center. Submitted to Steelcase Education Active Learning Center Grant. $(\$ 65,000$, not funded) ---Co-investigator

\section{SERVICE AND LEADERSHIP}

\section{UNIVERSITY HIGH SCHOOL}

Wellness Committee

2018- 2019

Served as a member on the Wellness Committee as a representative of the PE/Health Department. Tasked with overall school health improvement initiatives.

Grants Committee

2017- 2018

Served as a member on the Grants Committee as a representative of the health/PE department. Tasked with researching and attracting funding for PE/Health Department.

WEST VIRGINIA UNIVERSITY

President of CPASS Dean's Student Advisory Board

2016- 2017

Served as President on an interdisciplinary student board for the College of Physical Activity and Sports Sciences. The mission of the board was to promote interdisciplinary relationships, learning opportunities, and support charitable causes throughout the college greater community.

Student Mentor for Accelerated bachelor's to master's PETE program

Spring 2017

Served as an appointed student mentor to undergraduate students enrolled in the accelerated bachelor's to master's PETE program.

Kids' Safety and Fitness Expo

Spring 2017

Facilitated health and physical activity related stations for children during the annual WVU kids' safety and fitness expo.

CPASS Research Day

Spring 2017

Served as a reviewer for student research presentations during the annual CPASS research day.

WVU CPASS First Year Academy

Fall 2016 
Student volunteer for first year academy activities held within the college to promote student involvement and retention.

Dean's Student Advisory Board

2015- 2016

Served as a member on the College of Physical Activity and Sports Sciences student advisory board as a representative of the PETE programs. Tasked with fundraising opportunities within the college and greater community.

Kids Safety and Fitness Expo

Spring 2016

Facilitated health and physical activity related stations for children during the annual WVU kids' safety and fitness expo.

Silent Auction

Spring 2016

Facilitator of silent auction that was held in part to benefit a CPASS undergraduate scholarship. Tasked with attaining, filing, and promoting goods that would be auctioned off during the event.

Winter Commencement

Fall 2015

Facilitated the CPASS students and faculty during the WVU winter commencement ceremony.

Active Academics in-service

Spring 2015

Served as a volunteer presenter during an in-house Active Academics in-service. Led a presentation on active classrooms and the integration of activity breaks.

Winter Commencement

Fall 2014

Facilitated the CPASS students and faculty during the WVU winter commencement ceremony.

\section{COMMUNITY}

Angel Tree Holiday Drive for WellSpring of Greenbrier, WV

Fall 2016

Coordinator of Angel Tree Holiday Drive to benefit southern WV flood victims. Organized the collection and delivery of goods for over 150 individuals.

Boys and Girls Club of Fairmont, WV

Fall 2016

Provided presentation on ideas for afterschool physical activity interventions for non-profit.

Coca-Cola Fit Family Kickoff

Fall 2016

Assisted with the Coca-Cola Fit Family Kickoff held in McDowell County, WV. Promoted healthy choices and coordinated with partners during community $5 \mathrm{k}$.

West Virginia Center on Budget and Policy

Summer 2016

Served as a summit volunteer for the first annual summer policy institute.

Riegel Ridge Rams

2011- 2012

Served as a volunteer cheerleading coach for the Riegel Ridge Rams (NJ) program.

\section{HONORS AND AWARDS}

Dr. Patricia K. Fehl Graduate Scholarship

2017-2018

Award presented to a graduate student enrolled in one of the College of Physical Activity and Sport Sciences' Graduate Programs. Priority is given to a first-year doctoral student enrolled in Physical Education Teacher Education and who teaches in the College's Basic Instruction Program. 


\section{PROFESSIONAL ORGANIZATIONS}

Society of Health and Physical Educators- SHAPE America

West Virginia Association for Health, Physical Education, Recreation and Dance

National Consortium for Physical Education for Individuals with Disabilities 